
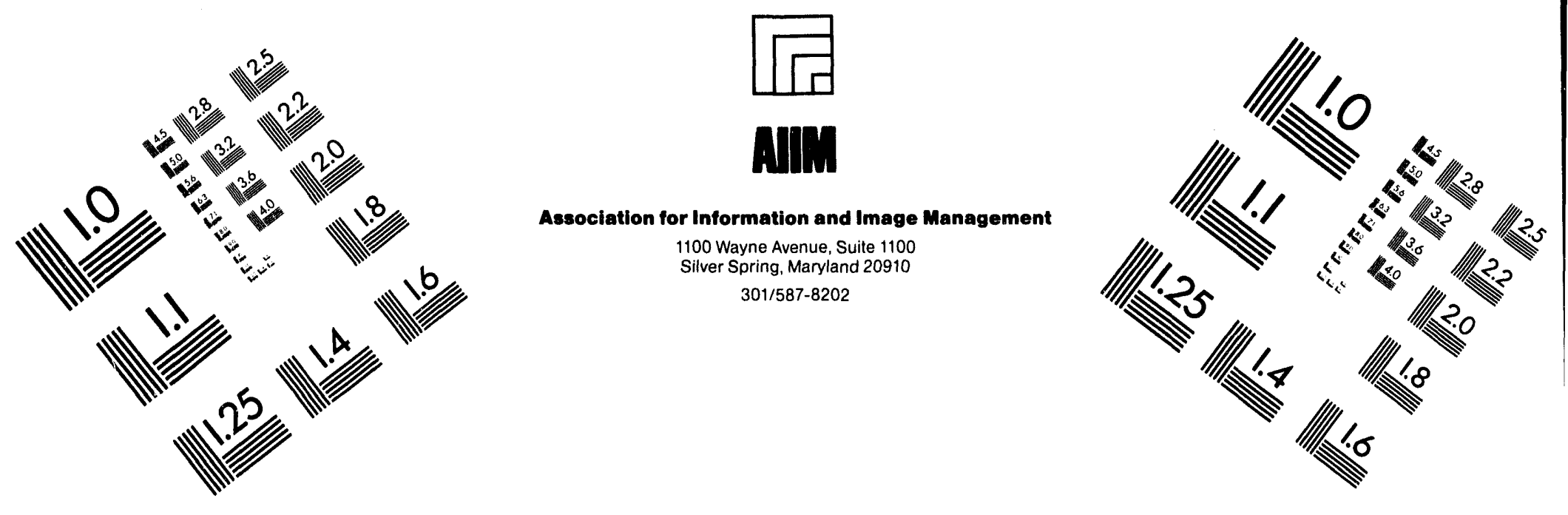

\title{
Centimeter
}

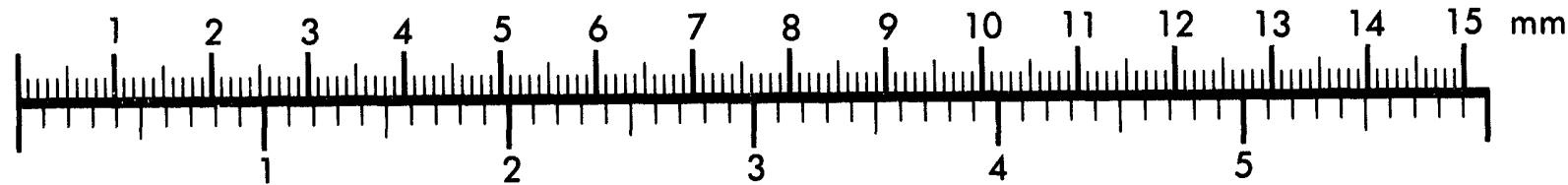
Inches
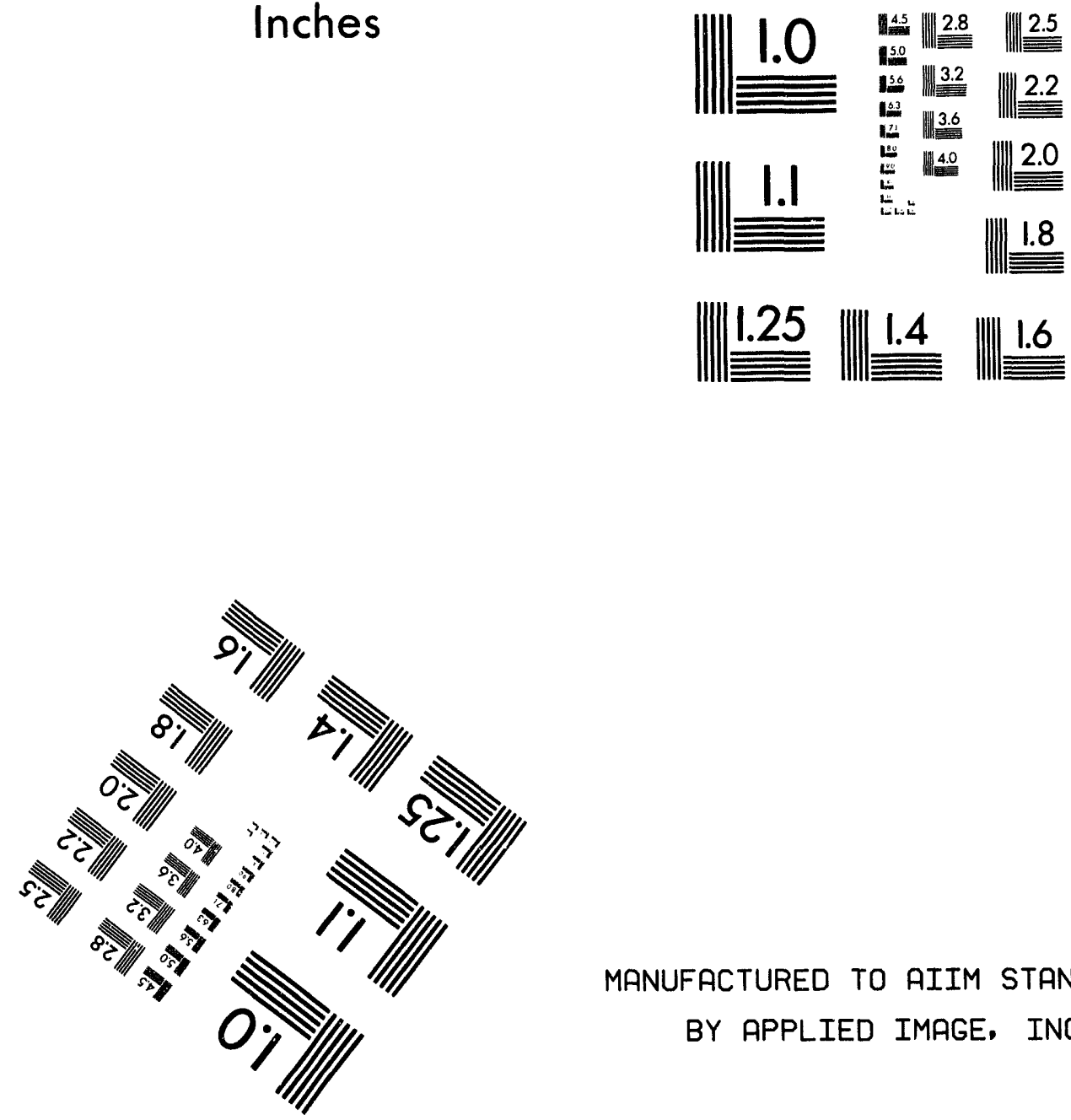

MANUFACTURED TO AIIM STANDARDS

BY APPLIED IMAGE, INC.

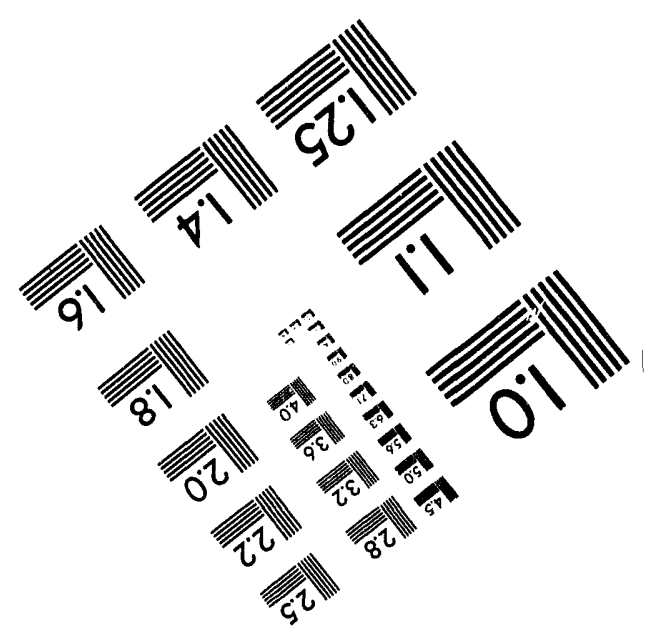



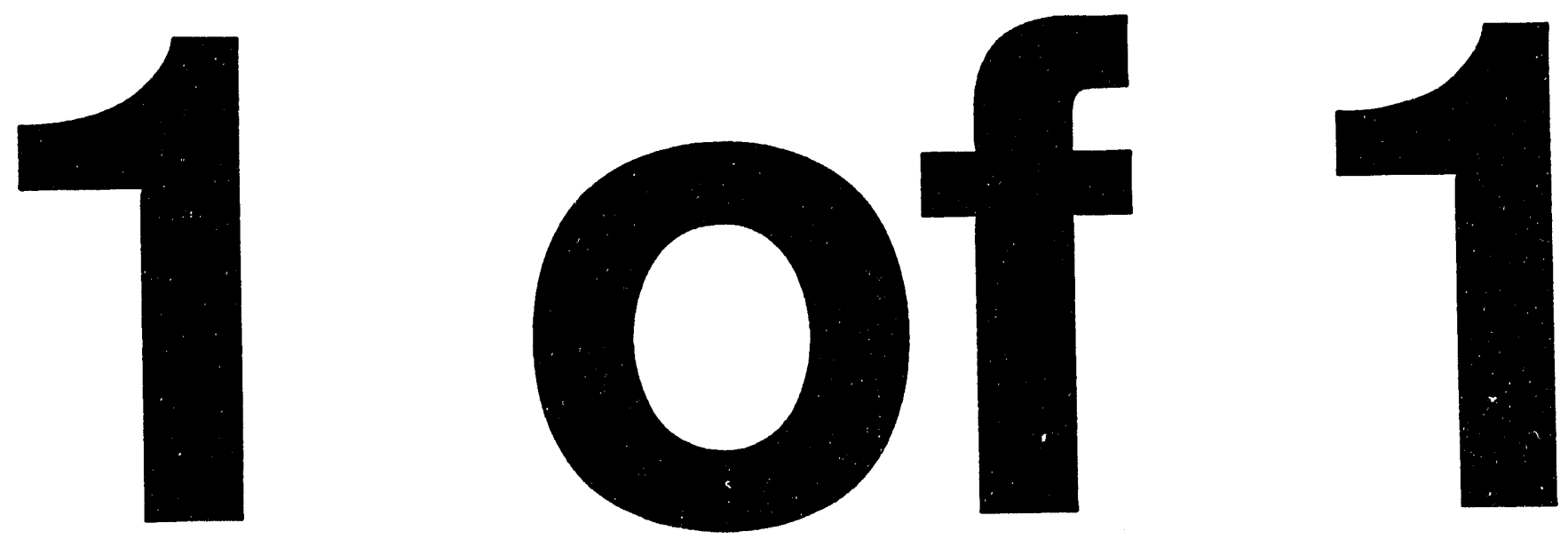


\section{INTENSIVE ARCHAEOLOGICAL SURVEY OF THE PROPOSED CENTRAL SANITARY WASTEWATER TREATMENT FACILITY, SAVANNAH RIVER SITE, AIKEN AND BARNWELL COUNTIES, SOUTH CAROLINA}

D. Keith Stephenson

Kenneth E. Sassaman

This study was conducted through funding provided by the United States Department of Energy under contract number DE-FC09-88SR15199.

$\checkmark$ This study was prepared as an account of work sponsored by the United States Government. Neither the United States nor the United States Department of Energy, nor their employees, nor any of their contractors, subcontractors, or their employees, make any warranty for the accuracy, completeness, or usefulness of any information, apparatus, product or process disclosed, or represent that its use would not infringe privately-owned rights.

Technical Report Series Number 19

November 1993 


\section{MANAGEMENT SUMMARY}

The project area for the proposed Central Sanitary Wastewater Treatment Facility on the Savannah River Site includes a six-acre tract along Fourmile Branch and $18 \mathrm{mi}(29 \mathrm{~km})$ of trunk line corridors. Archaeological investigations of the six-acre parcel resulted in the discovery of one small prehistoric site designated 38AK465. This cultural resource does not have the potential to add significantly to archaeological knowledge of human occupation in the region. The Savannah River Archaeological Research Program (SRARP) therefore recommends that 38AK465 is not eligible for nomination to the National Register of Historic Places (NRHP) and further recommends a determination of no effect. Archaeological survey along the trunk line corridors implicated previously recorded sites 38AK92, 38AK145, 38AK415, 38AK417, 38AK419, and 38AK436. Past disturbance from construction had severely disturbed 38AK92 and no archaeological evidence of 38AK145, 38AK419, and 38AK436 was recovered during survey. Lacking further evidence for the existence of these sites, the SRARP recommends that 38AK92, 38AK145, 38AK419, and 38AK436 are not eligible for nomination to the NRHP and thus warrant a determination of no effect. Two of these sites, 38AK415 and 38AK417, required further investigation to evaluate their archaeological significance. Both of the sites have the potential to yield significant data on the prehistoric period occupation of the Aiken Plateau and the SRARP recommends that they are eligible for nomination to the NRHP. The Savannah River Archaeological Research Program recommends that adverse effects to sites 38AK415 and 38AK417 from proposed construction can be mitigated through avoidance. 


\section{ACKNOWLEDGEMENTS}

Mr Joe. L. Ormond of Power Engineering and Mr. L. L. Clifton of Site Services Engineering, Westinghouse-Savannah River, supplied the Savannah River Archaeological Research Program with information to plan and implement archaeological survey of the proposed Central Sanitary Wastewater Treatment Facility. Their cooperation and assistance are gratefully acknowledged. The field crew consisted of Tammy Forehand, Chris Gillam, Bill Green, Tina Monaco, and Buddy Wingard. Chris Gillam produced most of the computer graphics in this report. SRARP Co-Program Manager Mark J. Brooks reviewed the report. 


\section{TABLE OF CONTENTS}

Management Summary ..................................................................................................

Acknowledgements ......................................................................................................................ii

List of Figures ....................................................................................................................... v

List of Tables .......................................................................................................................vii

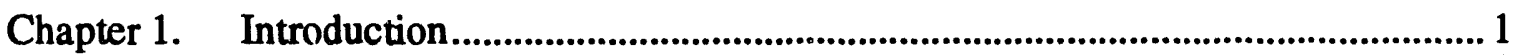

Project Background ........................................................................................................... 1

Project Area ................................................................................................................... 1

Synopsis of Results ....................................................................................................... 13

Chapter 2. Archaeological and Environmental Contexts ................................................ 14

Environment and Prehistoric Settlement Patterns...................................................... 14

Late Historic Period Settlement ....................................................................................... 19

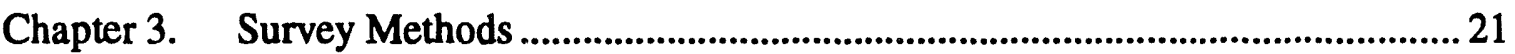

Previous Survey ………........................................................................................................ 21

Survey Design .................................................................................................................. 26

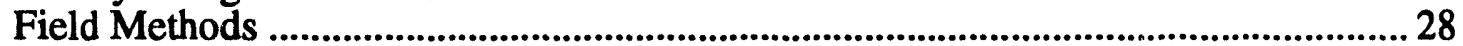

Survey of the Proposed Wastewater Facility Six-Acre Tract ................................... 28

Survey of the Proposed Wastewater Facility Trunk Line Routes .............................. 30

Summary .......................................................................................................................... 37

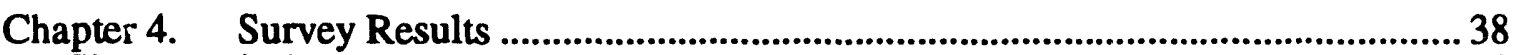

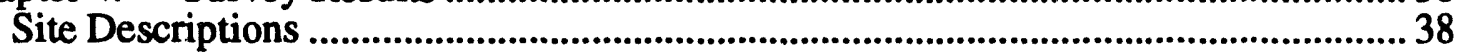

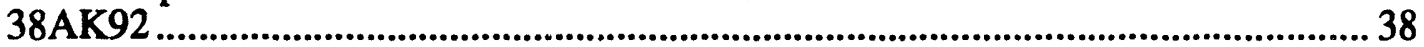

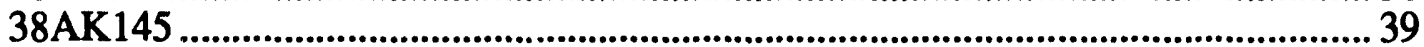

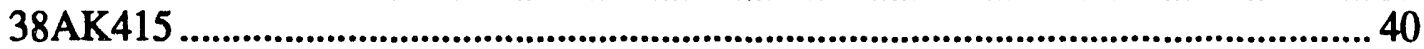

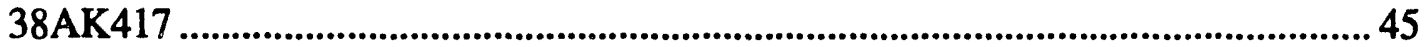

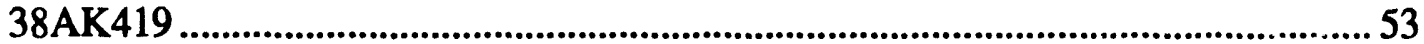

38AK436 ….................................................................................................... 53

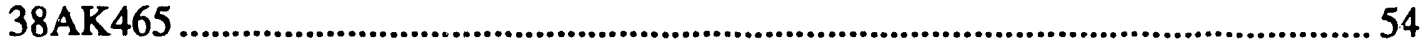

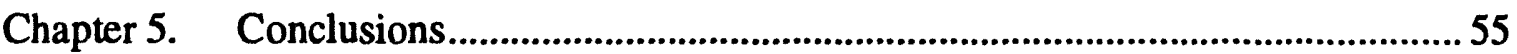

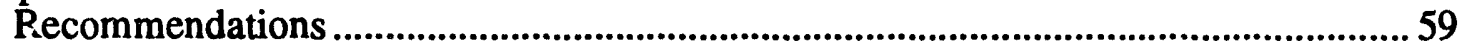

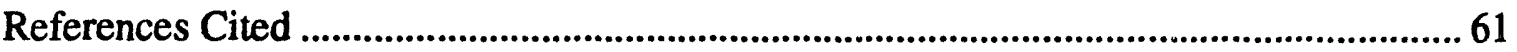




\section{LIST OF FIGURES}

Figure 1. Location of project area within Savannah River Site, South Carolina ............. 2

Figure 2. Location of project area sites 38AK145, 38AK415, 38AK417, 38AK419, and 38AK465 on USGS 7.5 topographic quad

New Ellenton, $\mathrm{SW}$

Figure 3. Location of project area sites 38AK92 and 38AK436

on USGS 7.5 topographic quad New Ellenton, SW 4

Figure 4. Project area for the Wastewater Facility showing six-acre tract and trunk line routes 5

Figure 5. Present condition of six-acre project area footprint.......................................... 6

Figure 6. Locations of photographs taken along trunk line routes.................................. 7

Figure 7. (View A) A-Area trunk line route looking south along Road D ...................... 8

Figure 8. (View B) A-Area trunk line route looking south along power line right-of-way

Figure 9. (View C) A-Area trunk line route along power line right-of-way overlooking Road C

Figure 10. (View D) A-Area trunk line route along Road C overlooking bridge spanning Upper Three Runs Creek.

Figure 11. (View E) H-Area trunk line route looking northeast along Road E with F-Area to the left.

Figure 12. (View F) Burma Road trunk line route looking southwest. 10

Figure 13. (View G) Location of steam line looking southwest along margin of Burma Road with site 38AK419 to the left

Figure 14. (View H) C/CS-Area trunk line route looking northwest along power line right-of-way

Figure 15. (View I) C/CS-Area trunk line route looking northwest where it will span Fourmile Branch.

Figure 16. (View J) Trunk line route looking southeast along power line right-of-way with proposed six-acre tract to the left

Figure 17. Physiography of the Savannah River Site area, showing location of project area

Figure 18. Locations of previous archaeological surveys in and around the Wastewater Facility project area.

Figure 19. Locations of previously recorded and new sites in and around the Wastewater Facility project area. 
Figure 20. Patrol Index Unit quadrants in and around the Wastewater Facility project area along Fourmile Branch

Figure 21. Sensitivity zones in the vicinity of the

Wastewater Facility six-acre tract

Figure 22. Map of Wastewater Facility six-acre tract showing location of firebreak and shovel test transects.

Figure 23. Location of Wastewater Facility survey loci along trunk line routes

Figure 24. Map of Survey Locus 1 along the A-Area trunk line route at site 38AK436

Figure 25. Map of Survey Locus 2 along the A-Area trunk line route at site 38AK145

Figure 26. Map of Survey Locus 3 along the Burma Road trunk line route 34

Figure 27. Map of Survey Locus 4 along the Burma Road trunk line route 35

Figure 28. Map of Survey Locus 5 along the Burma Road trunk line route at site 38AK419.

Figure 29. Map of site 38AK415 showing shovel test transects and test unit locations

Figure 30. Drawing and photograph of east profile, Provenience 17, 38AK415.

Figure 31. Map of site 38AK417 showing shovel test transects and test unit locations

Figure 32. Drawing and photograph of east profile, Provenience 10, 38AK417............ 50

Figure 33. Drawing and photograph of east profile, Provenience 14, 38AK417. 51 


\section{LIST OF TABLES}

Table 1. Survey and Site Information for Patrol Index Unit Quadrants (PIU Quads) in and around the Wastewater Facility Project Area along Fourmile Branch.............................................................................................. 26

Table 2. Archaeological Sensitivity Values for Wastewater Facility Trunk Line Routes 28

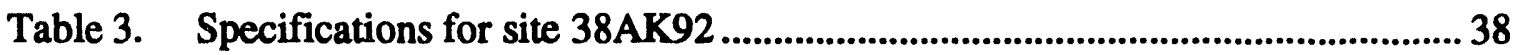

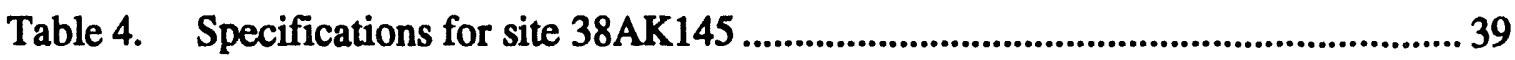

Table 5. Specifications for site 38AK415 ................................................................. 41

Table 6. Artifact Inventory by Shovel Test Provenience, 38AK415 .............................. 42

Table 7. Provenience 17 Artifact Inventory by Level, 38AK415 ...................................44

Table 8. Provenience 17 Debitage Data by Level, 38AK415 ........................................ 44

Table 9. Specifications for site 38AK417 .........................................................................46

Table 10. Ceramic Artifact Inventory by Provenience from 1984 Survey, 38AK417 ................................................................................ 48

Table 11. Lithic Artifact Inventory by Provenience

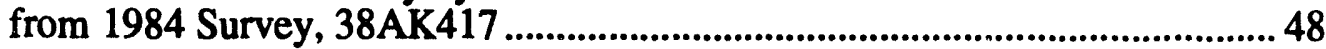

Table 12. Artifact Inventory by Shovel Test Provenience, 38AK417 ............................. 49

Table 13. Provenience 10 Artifact Inventory by Level, 38AK417 .................................52

Table 14. Provenience 14 Artifact Inventory by Level, 38AK417 ................................ 52

Table 15. Specifications for site 38AK419 ................................................................53

Table 16. Specifications for site 38AK436 ................................................................54

Table 17. Specifications for site 38AK465 …..............................................................54

Table 18. Combined Recovery Data from Previous and Recent Survey for Sites Located in the Wastewater Facility Project Area......................................55

Table 19. Recovery Data for Prehistoric Sites Located in the F/H Tract Project Areas

Table 20. Comparisons of Test Unit Artifact Density and Size for Sites along Fourmile Branch and Upper Three Runs Creek.

Table 21. Evaluation and Recommendations for Sites in the Wastewater Facility Project Area .60 


\section{CHAPTER 1 \\ INTRODUCTION}

Described in this report are the results of an intensive archaeological survey of the proposed Central Sanitary Wastewater Treatment Facility on the United States Department of Energy's Savannah River Site in Aiken and Barnwell Counties, South Carolina (Figure 1). Pedestrian and subsurface techniques of archaeological survey were employed to investigate a six-acre facility location and $29 \mathrm{~km}$ of associated trunk line routes. Altogether, seven archaeological sites were implicated for review and evaluation in the project area. The location of these sites are depicted on a USGS 7.5 topographic quad map in Figures 2 and 3 along with the project area boundaries and routes. In anticipation of severe land alteration within the six-acre footprint, an intensive survey effort was conducted to locate archaeological resources. This work resulted in the discovery of a single prehistoric site designated 38AK465. Based on the limited extent and content of cultural material, this site does not have the potential to yield significant information about human occupation in the study area and is therefore considered ineligible by the SRARP for nomination to the National Register of Historic Places (NRHP). Survey efforts along the trunk line routes were conducted primarily to relocate existing sites as most of this area had been surveyed during previous projects. Six archaeological sites were targeted for investigation. Of these, only two (38AK415 and 38AK417) were relocated and evaluated. Both sites yielded primarily Woodland period artifacts (ca. 2500-1000 years before present). Although the sites have been disturbed by plowing, logging, and rights-of-way, they contain intact prehistoric components with sufficient research potential to be eligible for nomination to the NRHP. No archaeological evidence of previously recorded sites $38 \mathrm{AK} 145,38 \mathrm{AK} 419$, and 38AK436 was recovered during survey and past disturbance from construction had severely disturbed 38AK92. Thus, these sites are recommended by the SRARP as ineligible for nomination to the NRHP and thus warrant a determination of no effect.

\section{Project Background}

The initial proposal to build a Central Sanitary Wastewater Treatment Facility (hereafter referred to as Wastewater Facility) on the Savannah River Site (SRS) was issued in a Preliminary Site Use Review Application (SU Log Number 602) in October of 1991. The official SR-88 Site Use Review Application (Number 93-18-C) was received by the Savannah River Archaeological Research Program (SRARP) in March of 1993. Archaeological survey of the proposed Wastewater Facility and associated trunk line corridors was initiated in April of 1992 and continued intermittently until August when the survey effort was temporarily aborted in response to engineering changes in trunk line routes. Prior to this unexpected redesign, SRARP personnel had surveyed the Wastewater Facility location and trunk lines in the immediate vicinity. Pending notification of the trunk line re-route, a preliminary report of the survey results was completed for inclusion in the FY92 Annual Review of Cultural Resource Investigations (SRARP 1992:10-11). In August of 1992, Site Services Engineer L. L. Clifton forwarded a copy of the trunk line route revision to the SRARP. With this information, the trunk line survey resumed in December and continued intermittently until completion in July of 1993.

\section{Project Area}

The proposed Wastewater Facility is a centralized sewage treatment plant that will service various existing facilities on the SRS. The project area includes a six-acre tract located along the northwest margin of Fourmile Branch and $29 \mathrm{~km}(18 \mathrm{mi})$ of trunk line 


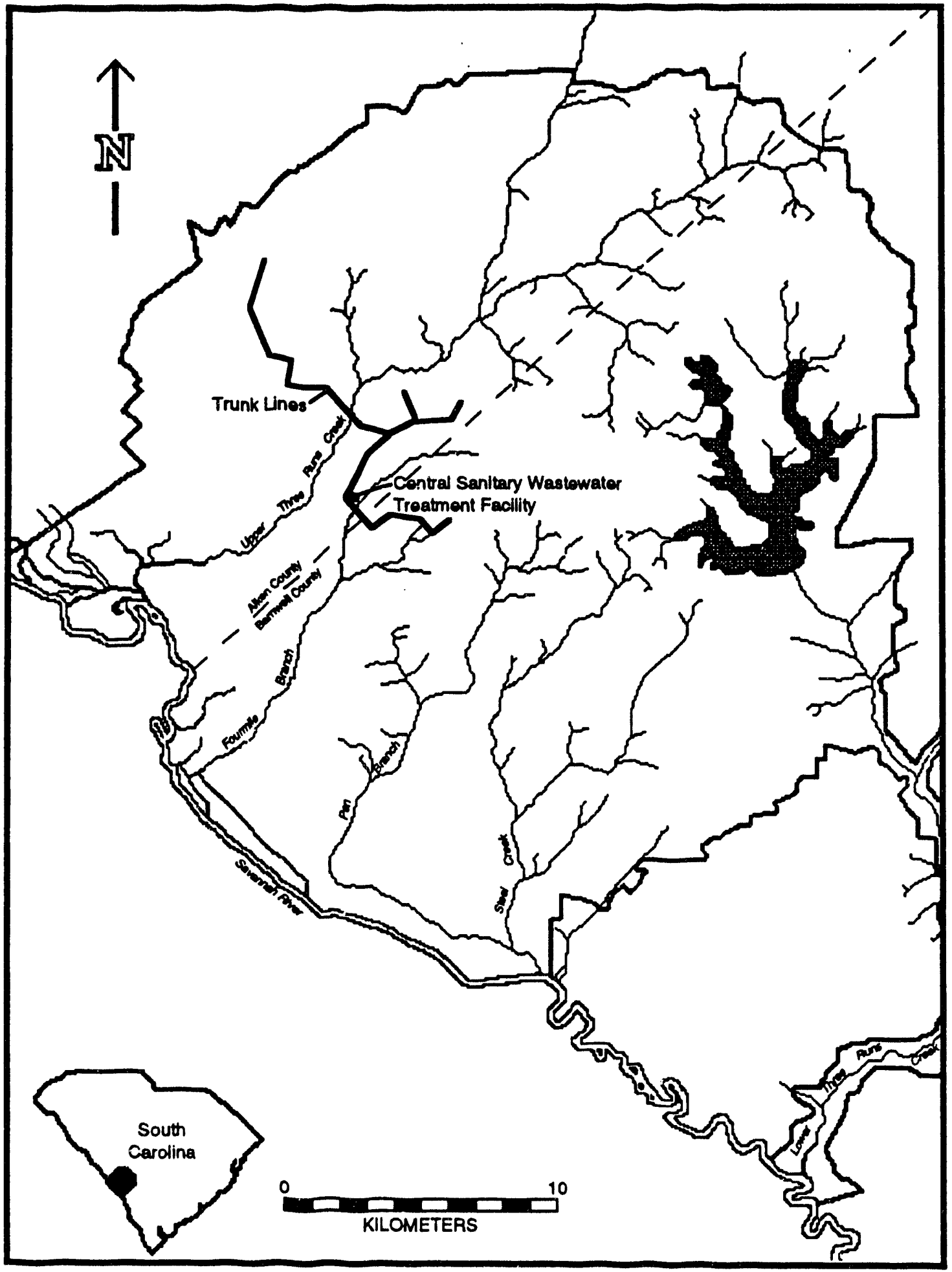

Figure 1. Location of project area within Savannah River Site, South Carolina. 


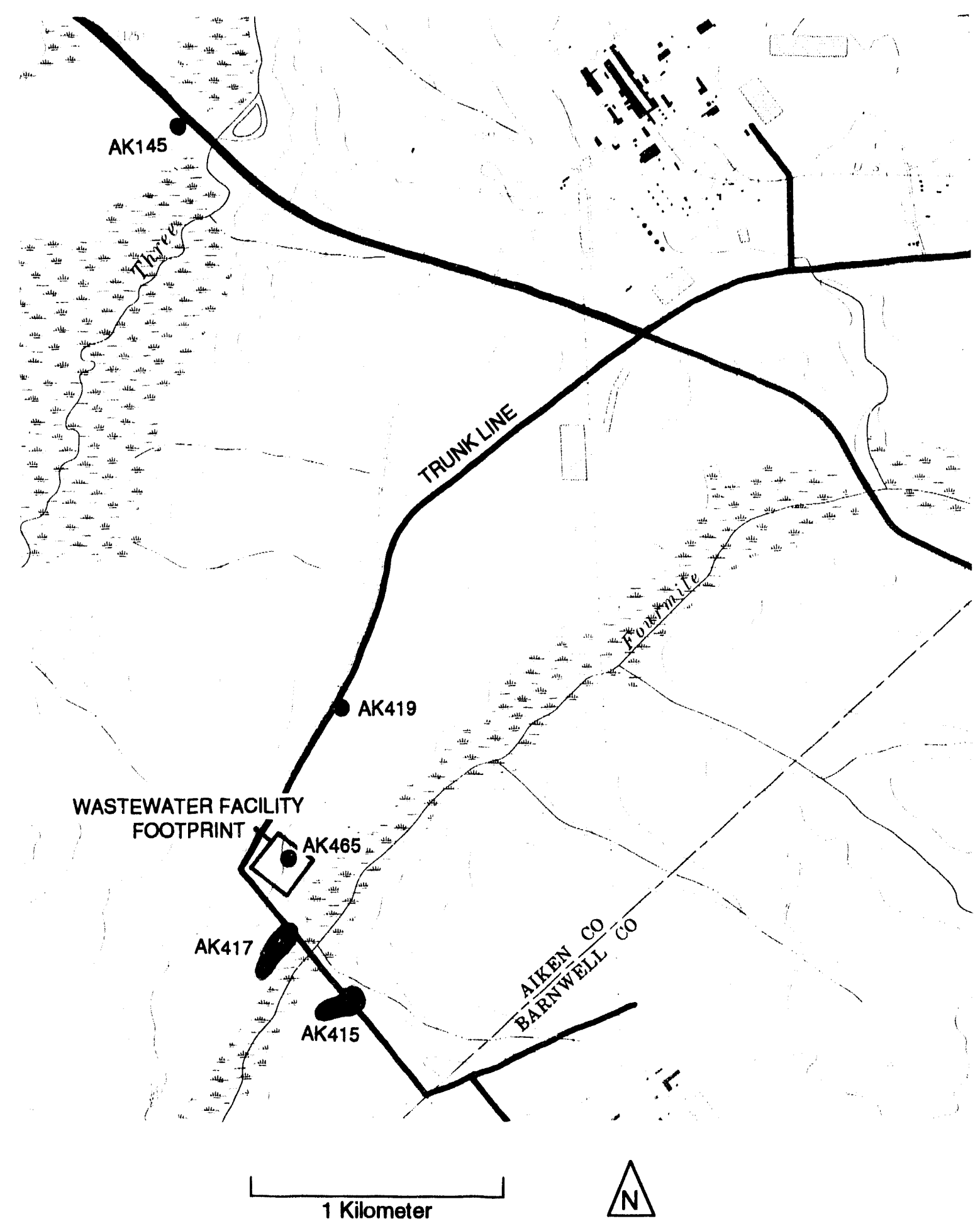

Figure 2. Location of project area sites 38AK145, 38AK415, 38AK417, 38AK419 and 38AK 465 on USGS 7.5 topographic quad New Ellenton, SW. 


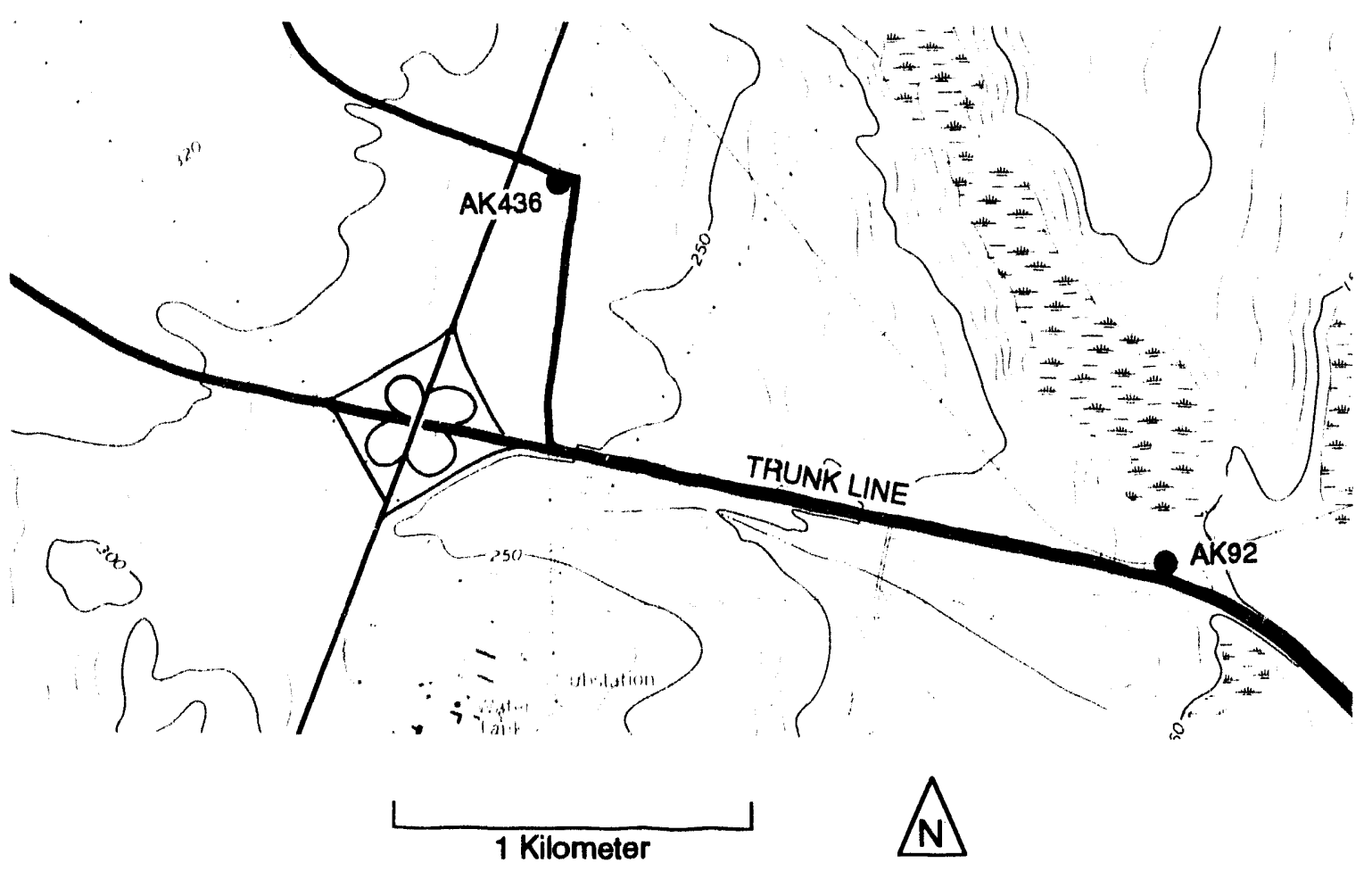

Figure 3. Location of project area sites 38AK92 and 38AK436 on USGS 7.5 topographic quad New Ellenton, SW.

corridors (Figure 4). The six-acre parcel is bounded on the northwest by Burma Road, an existing power line right-of-way to the southwest, the floodplain to the southeast, and a stand of planted pines to the northeast. This project footprint is situated approximately 250 $\mathrm{m}$ northwest of Fourmile Branch on a gentle ridge slope with surface elevations ranging

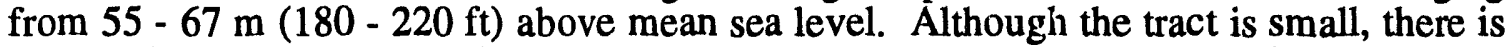
potential for archaeological resources on its southeastern perimeter, which fronts the floodplain of Fourmile Branch, a Rank 3 stream that drains the lower portion of the Aiken Plateau.

The ridge slope soil types in the six-acre tract consist of well drained sandy sediments of the Troup series and, to a lesser extent, excessively drained sand of the Blanton series (Rogers 1990:13, 31-32, soil map 21). The vegetation is predominantly shortleaf pine (Pinus echincta) interspersed with scrub oak (Quercus spp.) (Figure 5). A mid-twentieth century aerial photograph (United States Atomic Energy Commission Aerial Photograph 1951) shows the study area and adjacent land to the southwest and northeast as agricultural fields. Situated on the lower elevations of the ridge slope is a vegetational transition zone consisting primarily of pines, hardwoods, and swamp palmetto (Sabal minor). This mesic environment is sustained on well drained, moderately permeable soils of the Lucy series. The bottomland/swamp soils of the Fourmile Branch floodplain are formed in poorly drained, moderately permeable fluvaquents (Rogers 1990:16-17, 22-23, soil map 21).

The extensive network of underground collection piping, referred to as trunk lines, will be constructed from existing facilities on the SRS to the centralized treatment plant 


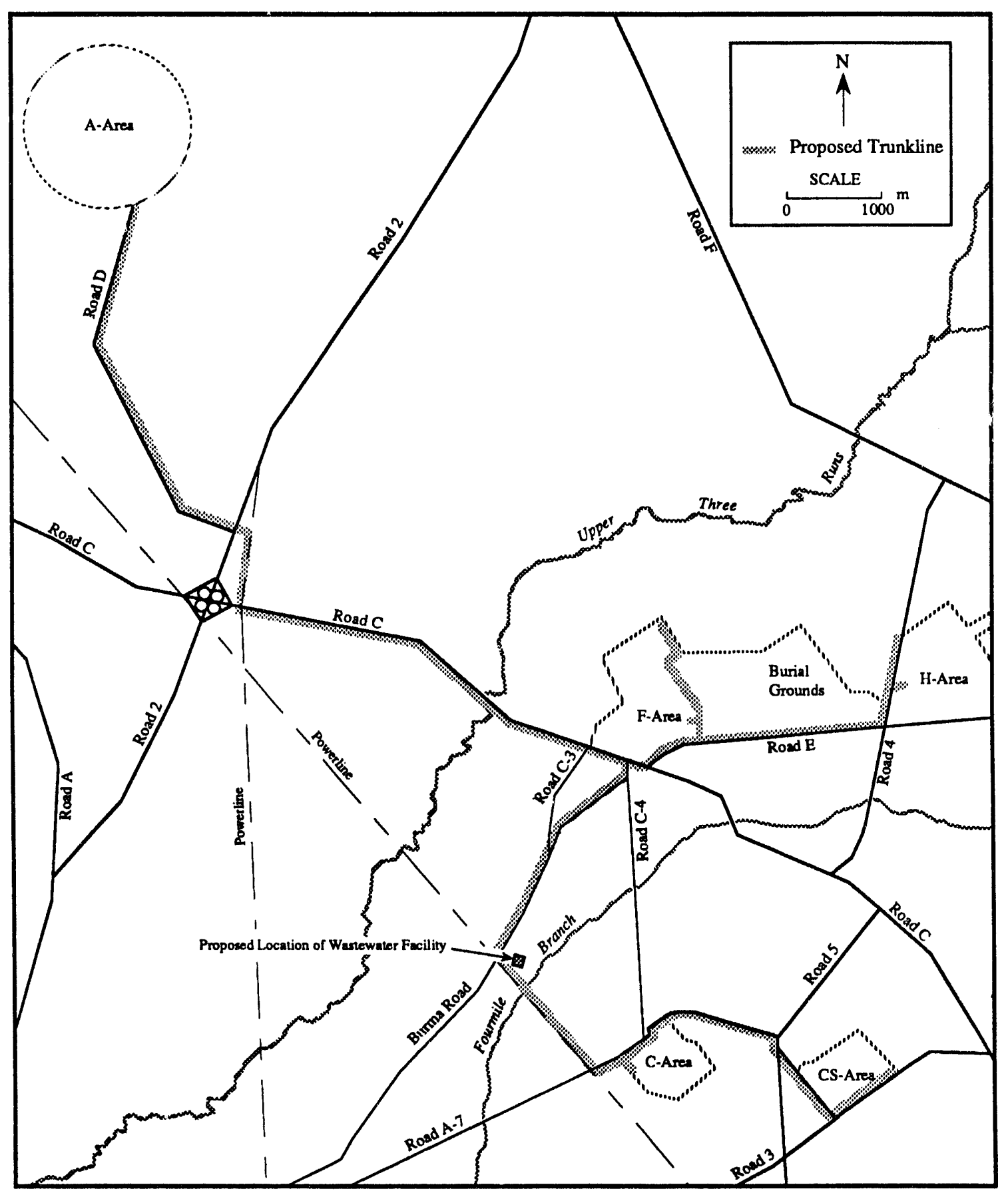

Figure 4. Project area for the Wastewater Facility showing six-acre tract and trunk line routes. 


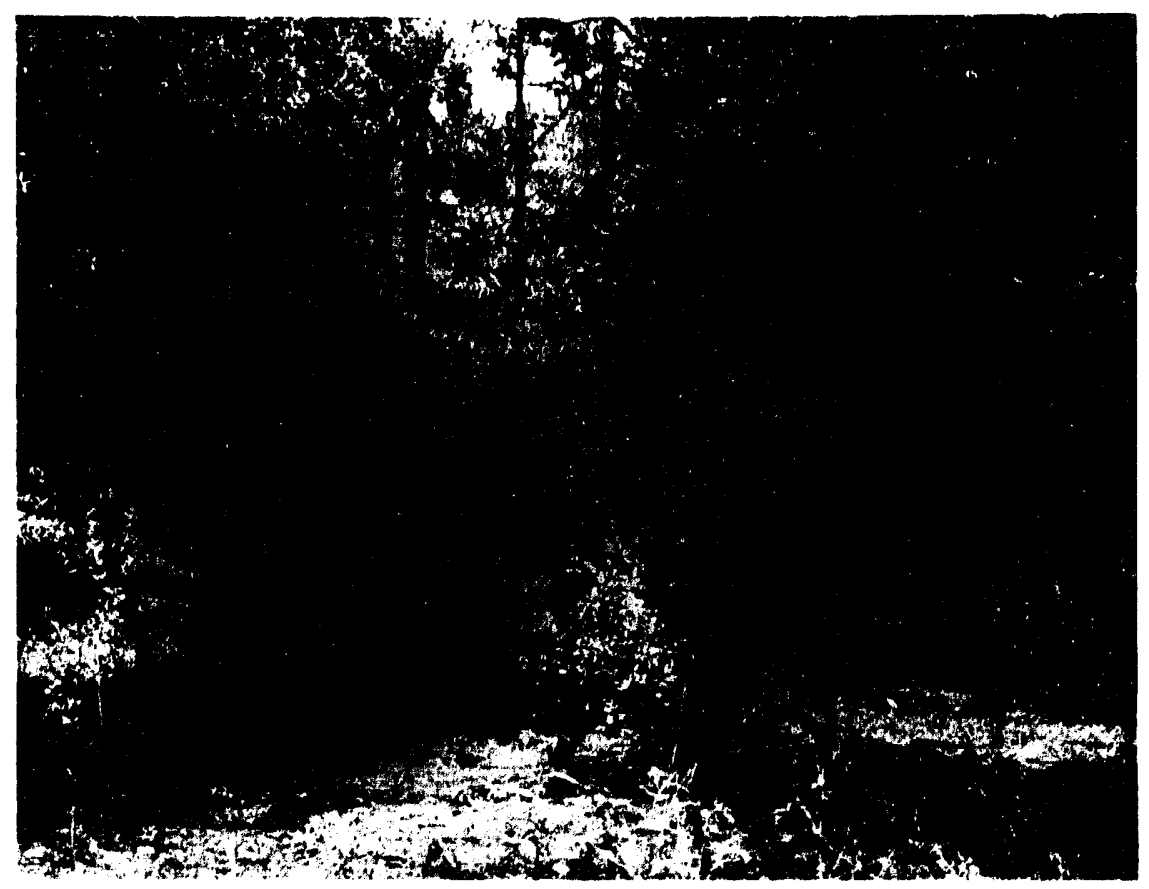

Figure 5. Present condition of six-acre project area footprint.

along Fourmile Branch. The routes originate at three separate locations: A-Area, C/CSArea, and H-Area. Additional spur-lines along the H-Area route will service the FArea/Burial Grounds facilities. A series of photographs was shot along the various trunk line routes to illustrate present conditions. The location of each photograph is shown in Figure 6 with the corresponding pictures in Figures 7 though 16. The initial portion of the A-Area route lies along the west shoulder of Road D as indicated by the placement of wooden surveyor's stakes (Figure 7). At its intersection with Road 2, the A-Area route skirts the cloverleaf intersection on the east by following an existing power line right-ofway (Figures 8 and 9). Finally, the A-Area route follows Road C to the east where it will span Upper Three Runs by way of an existing bridge (Figure 10) continuing along Road C and ending at the Burma Road intersection. The H-Area trunk line route originates along Road 4 and continues west along Road E where it services F-Area and the Burial Grounds (Figure 11). From this point, it crosses Road C and follows Burma Road, an improved, gravel-paved thoroughfare (Figures 12 and 13), to the Wastewater Facility. The C/CSArea route originates along Road A-7 and follows a power line right-of-way northward (Figure 14) where it spans Fourmile Branch (Figure 15) and continues along the power line cut to the Wastewater Facility (Figure 16). Portions of the various routes fall within areas that are excluded from archaeological survey such as F-Area, C-Area, H-Area, and the Burial Grounds. Since the early 1950s, construction in these areas has been particularly heavy, assuring the destruction of any archaeological resources.

As is evident from the trunk line route description, all corridors follow existing rights-of-way such as road shoulders and power line cuts. The underground piping will be laid at a distance of $35-45 \mathrm{ft}(11-14 \mathrm{~m})$ from roadways. For most of the route, this 


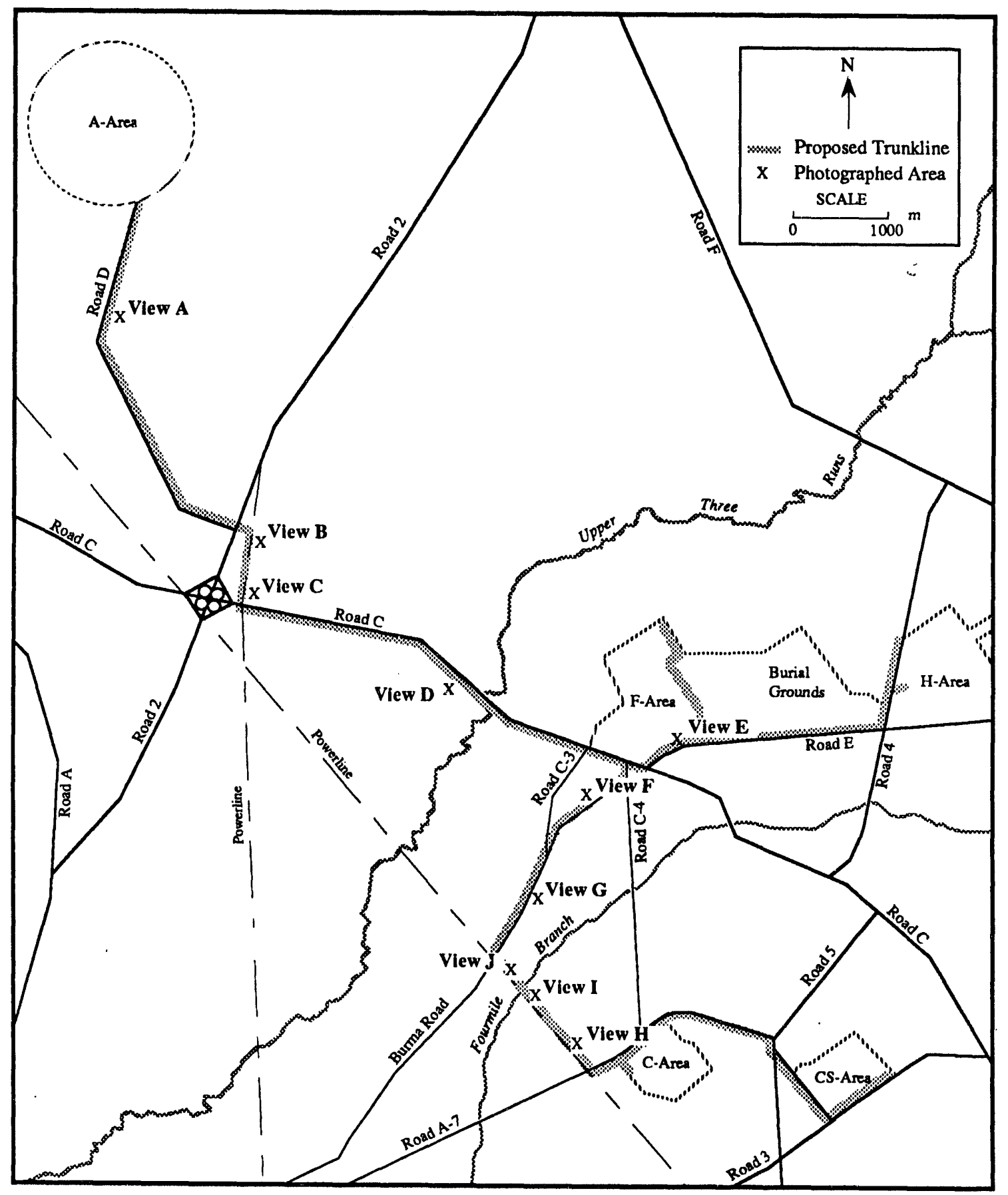

Figure 6. Locations of photographs taken along trunk line routes. 

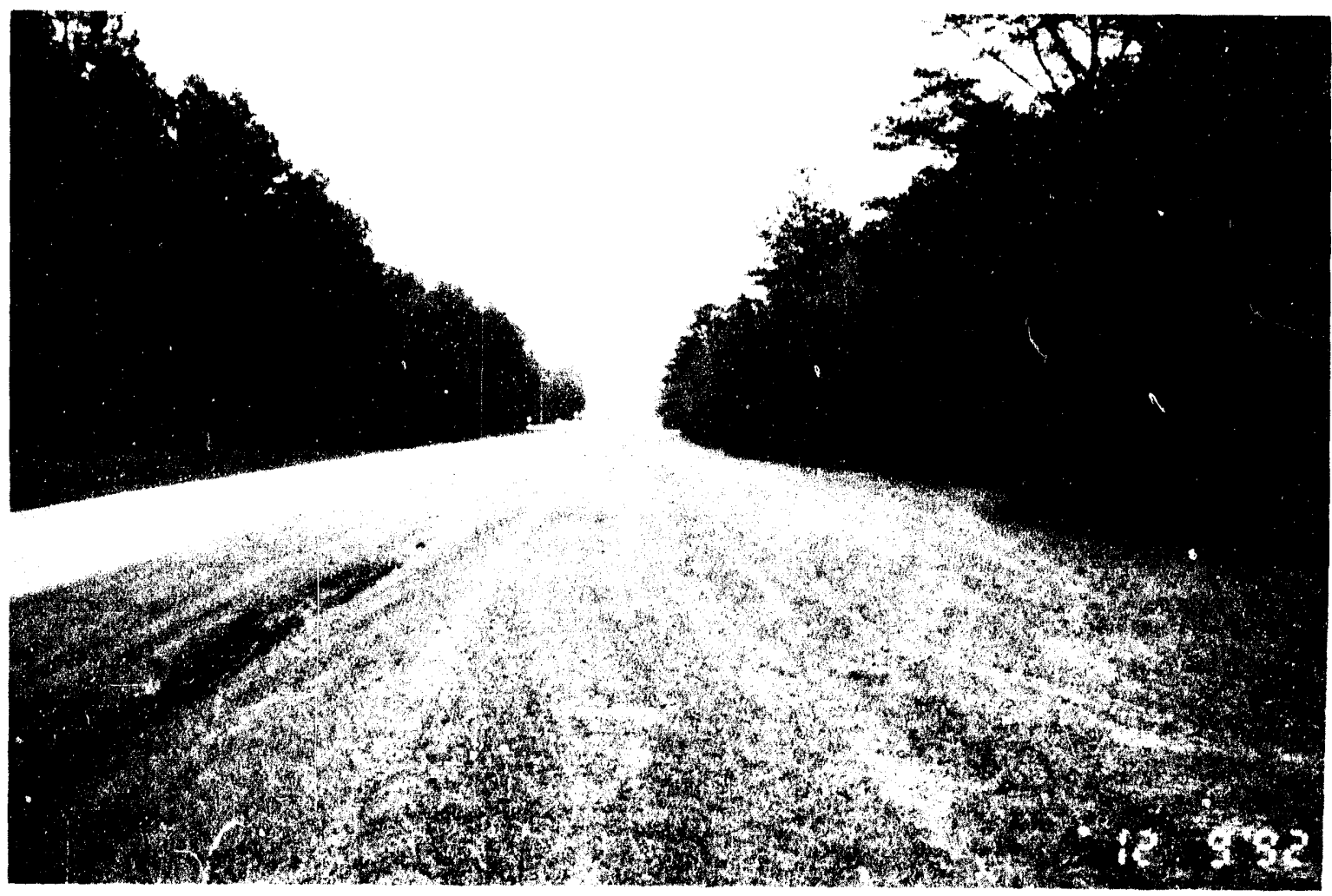

Figure 7. (View A) A-Area trunk line looking south route along Road D.

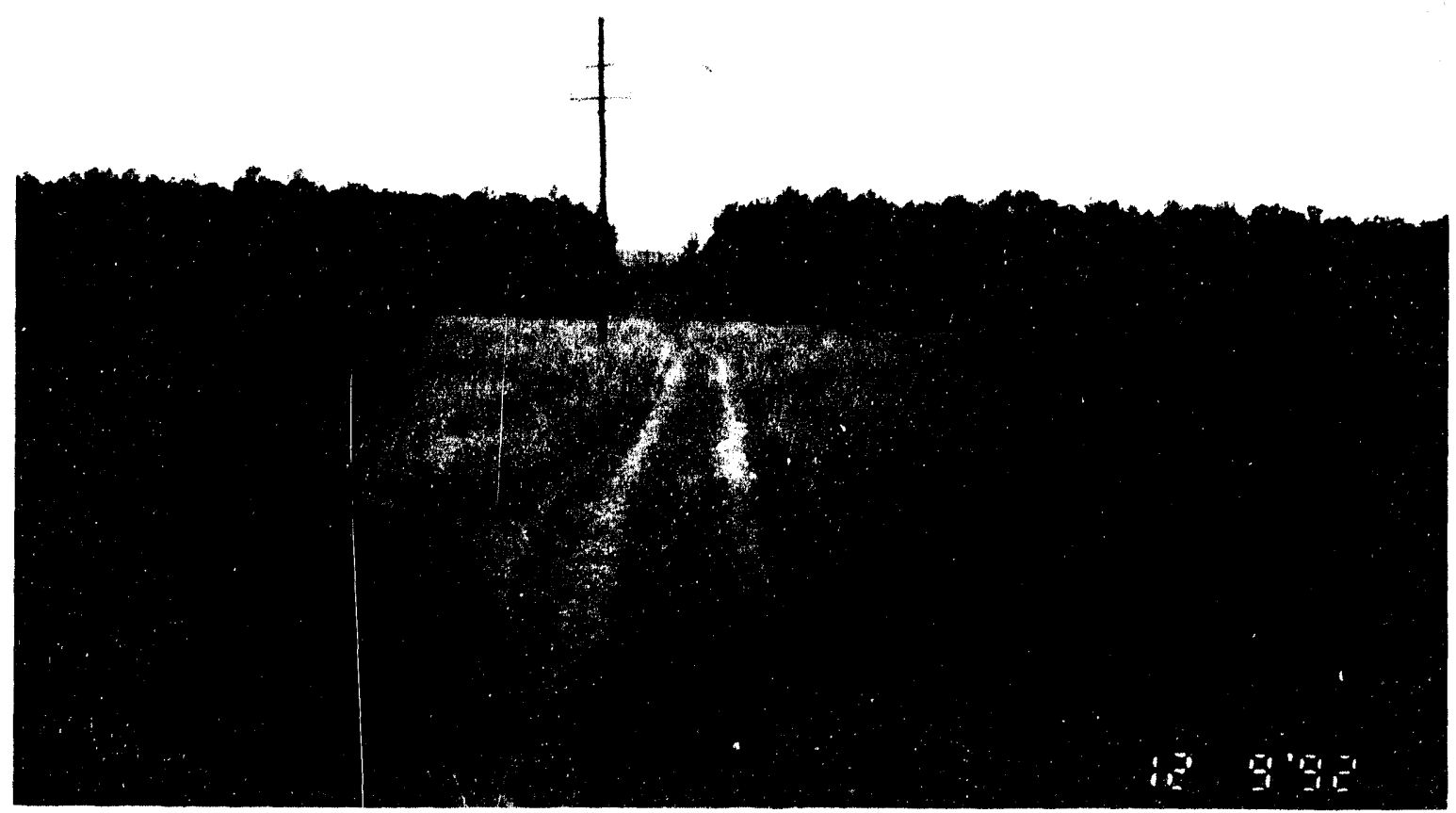

Figure 8. (View B) A-Area trunk line route looking south along power line right-of-way. 


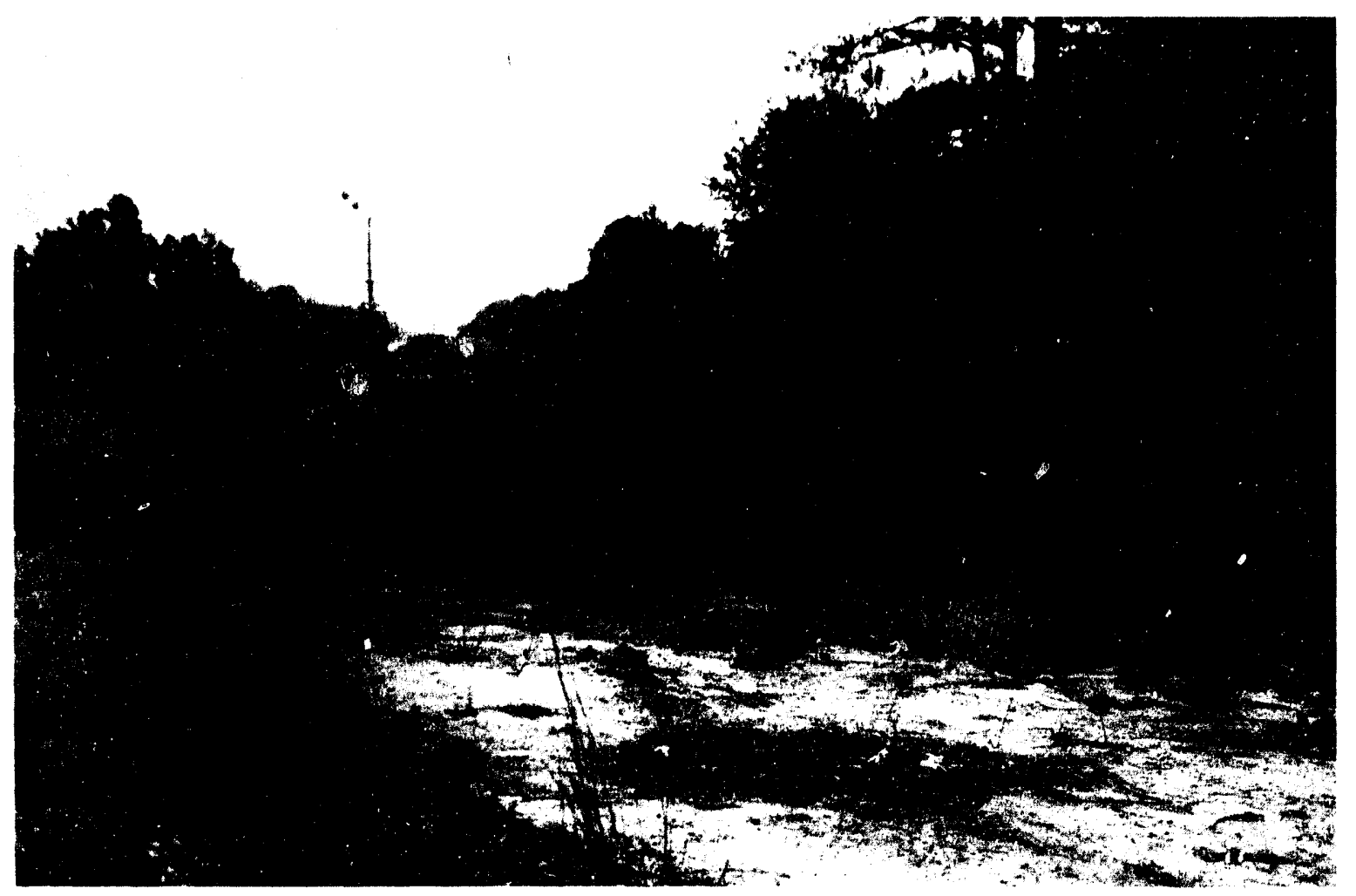

Figure 9. (View C) A-Area trunk line route along power line right-of-way overlooking Road C.

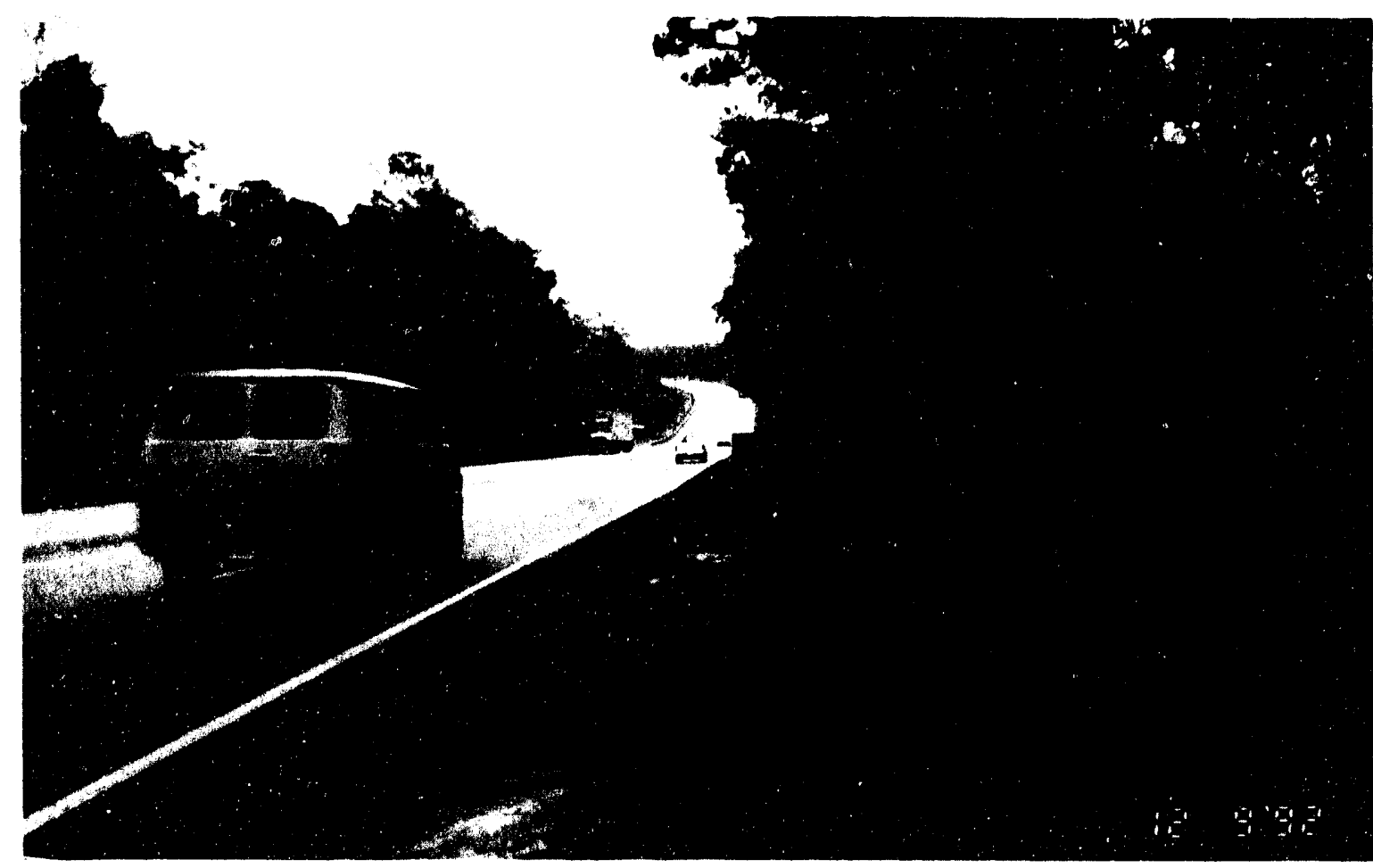

Figure 10. (View D) A-Area trunk line route along Road C oveilooking

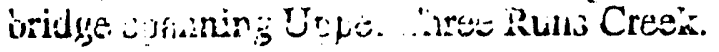




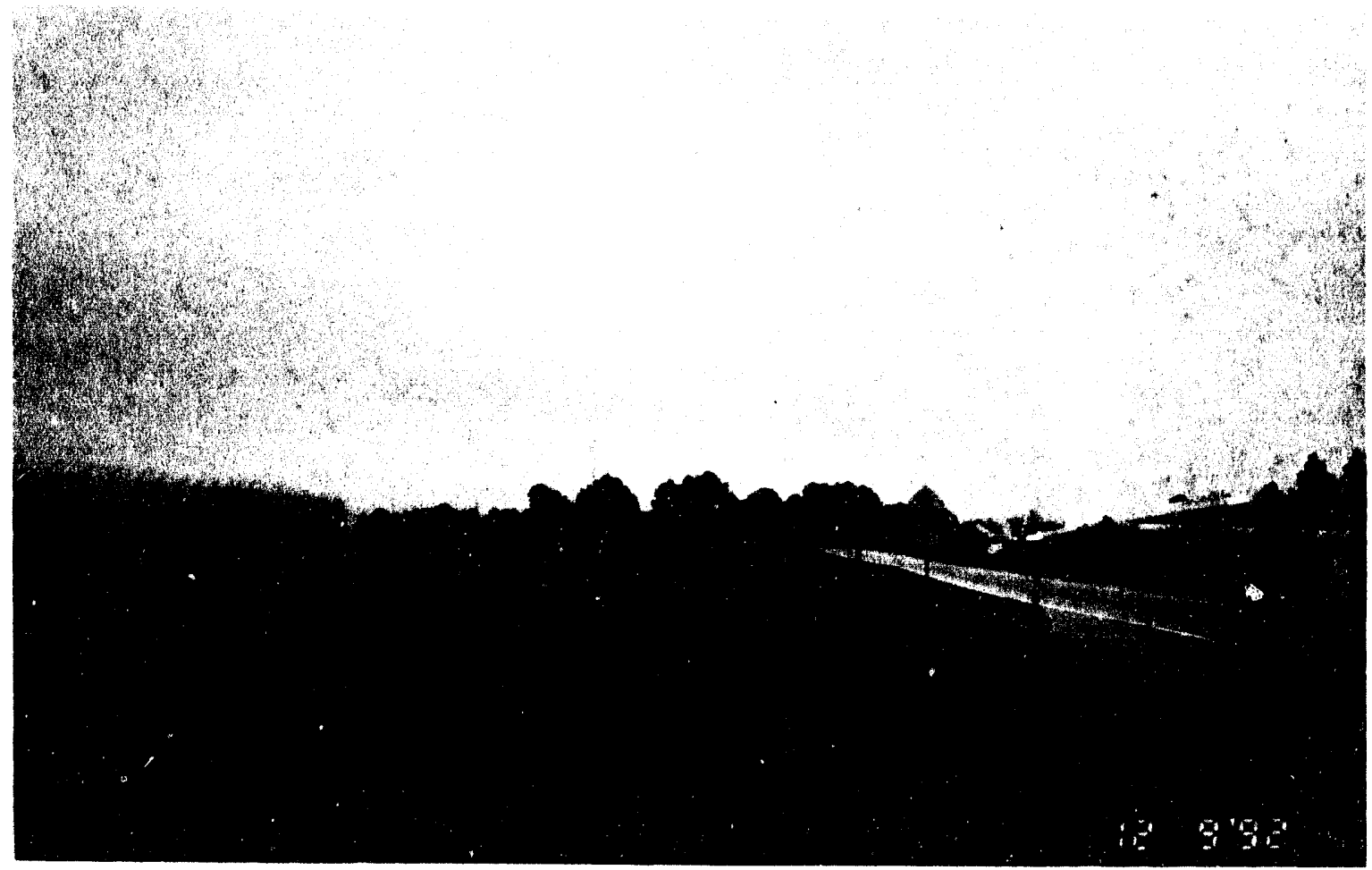

Figure 11. (View E) H-Area trunk line route looking northeast along Road E with F-Area to the left.

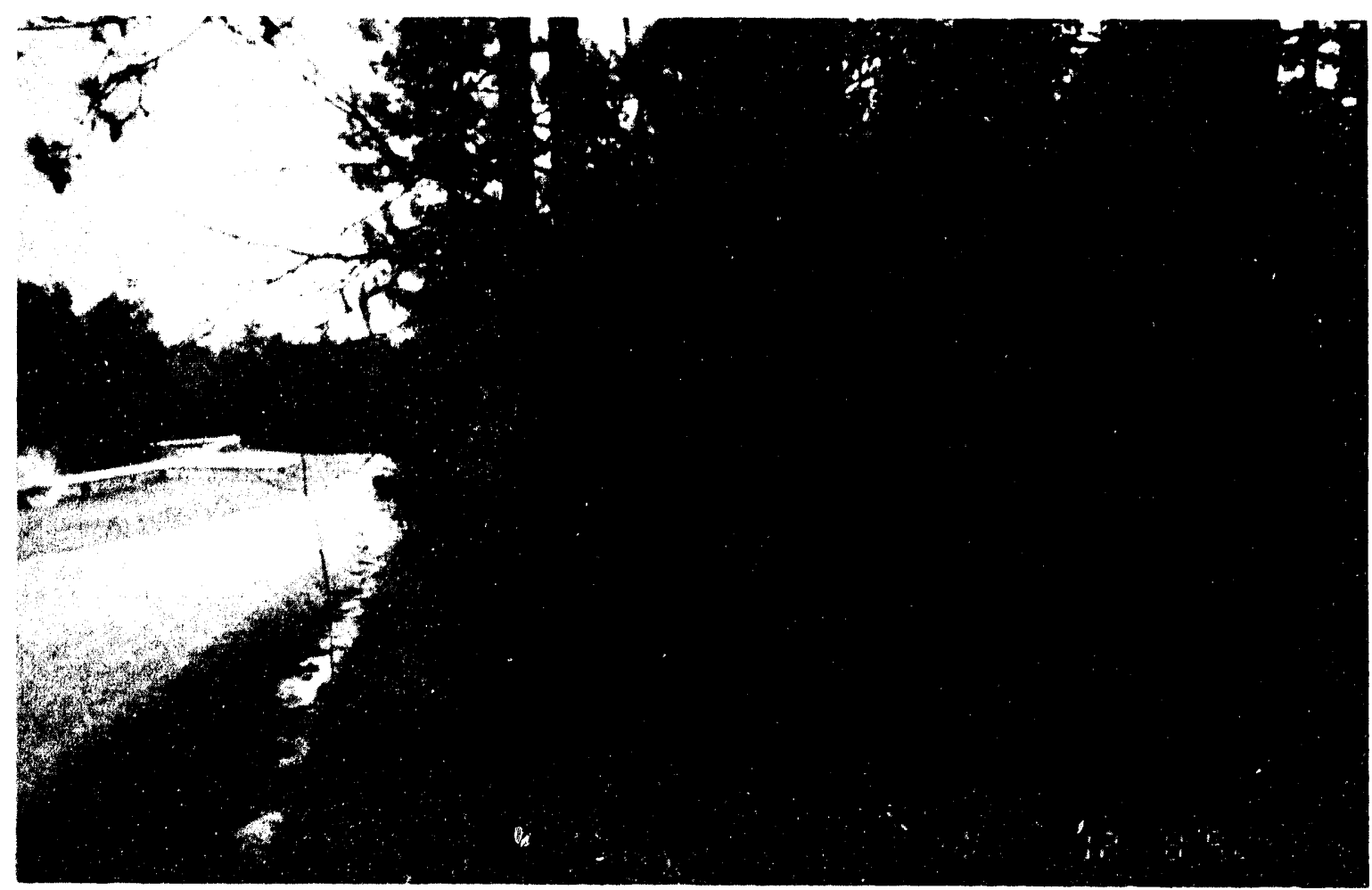

Figure 12. (View F) Burma Road trunk line route looking southwest. 


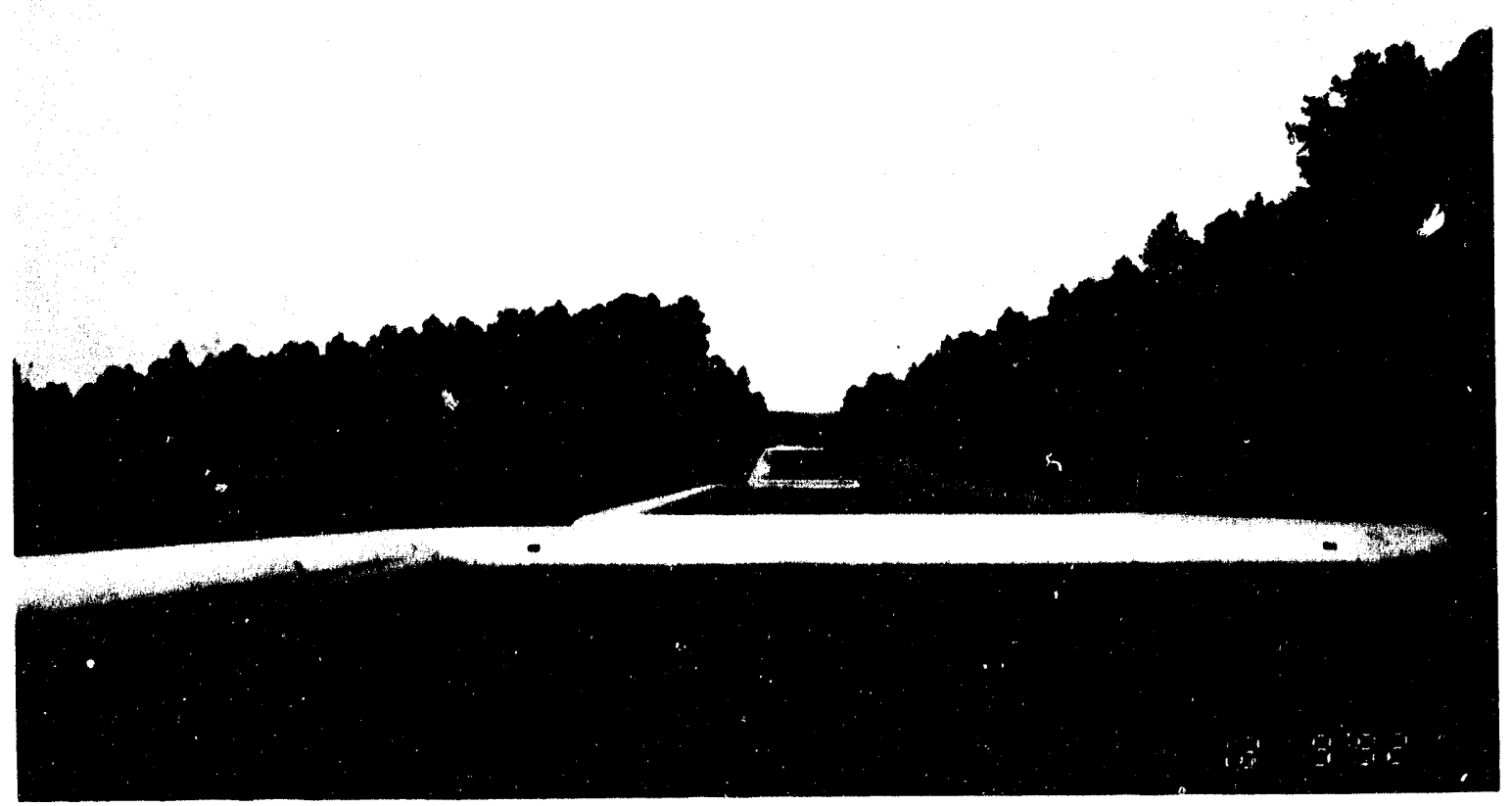

Figure 13. (View G) Location of steam line looking southwest along margin of Burma Road with site 38AK419 to the left.

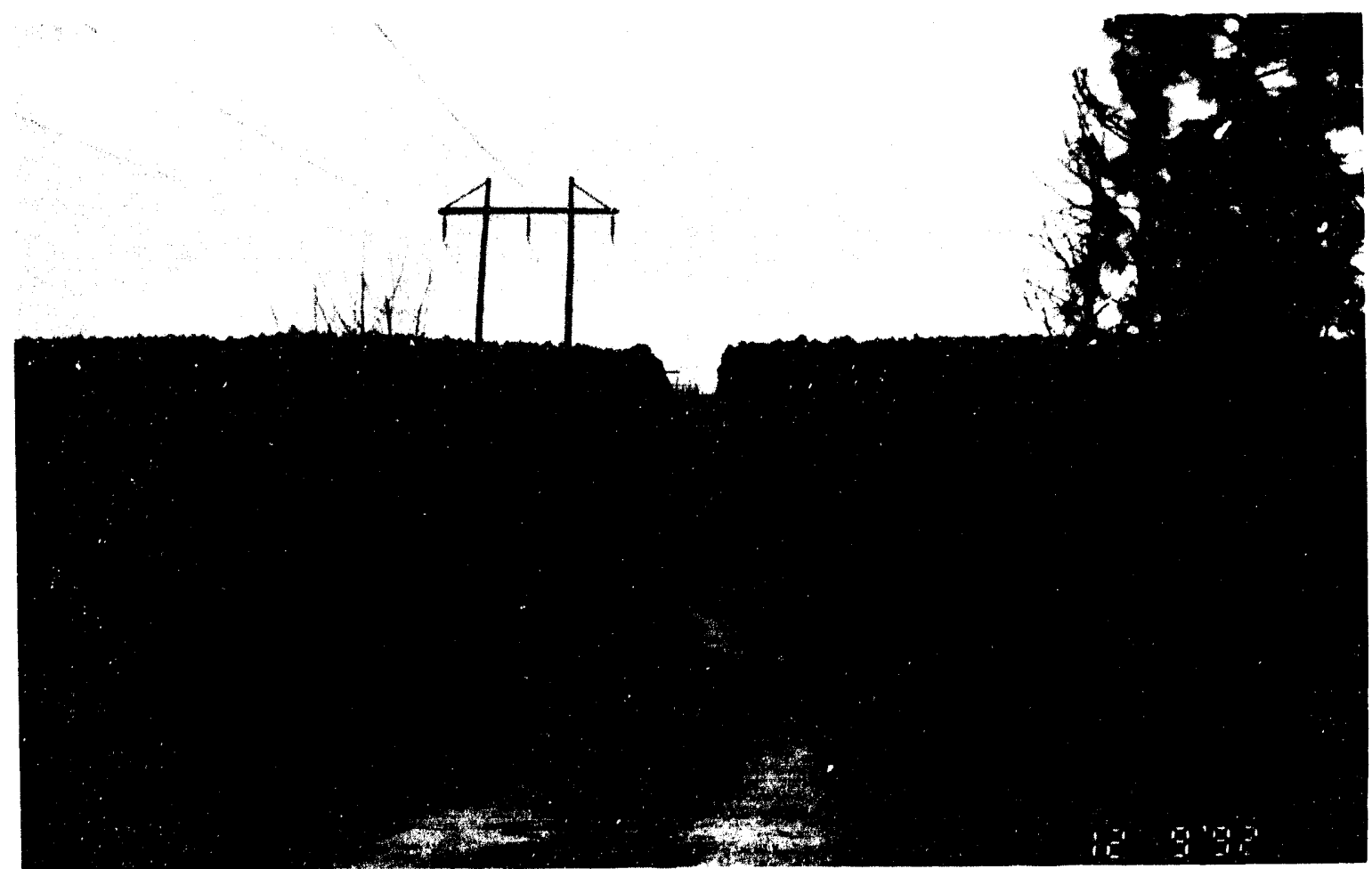

Figure 14. (View H) CiCS-Area trunk line route looking northwest along power line right-of-way. 


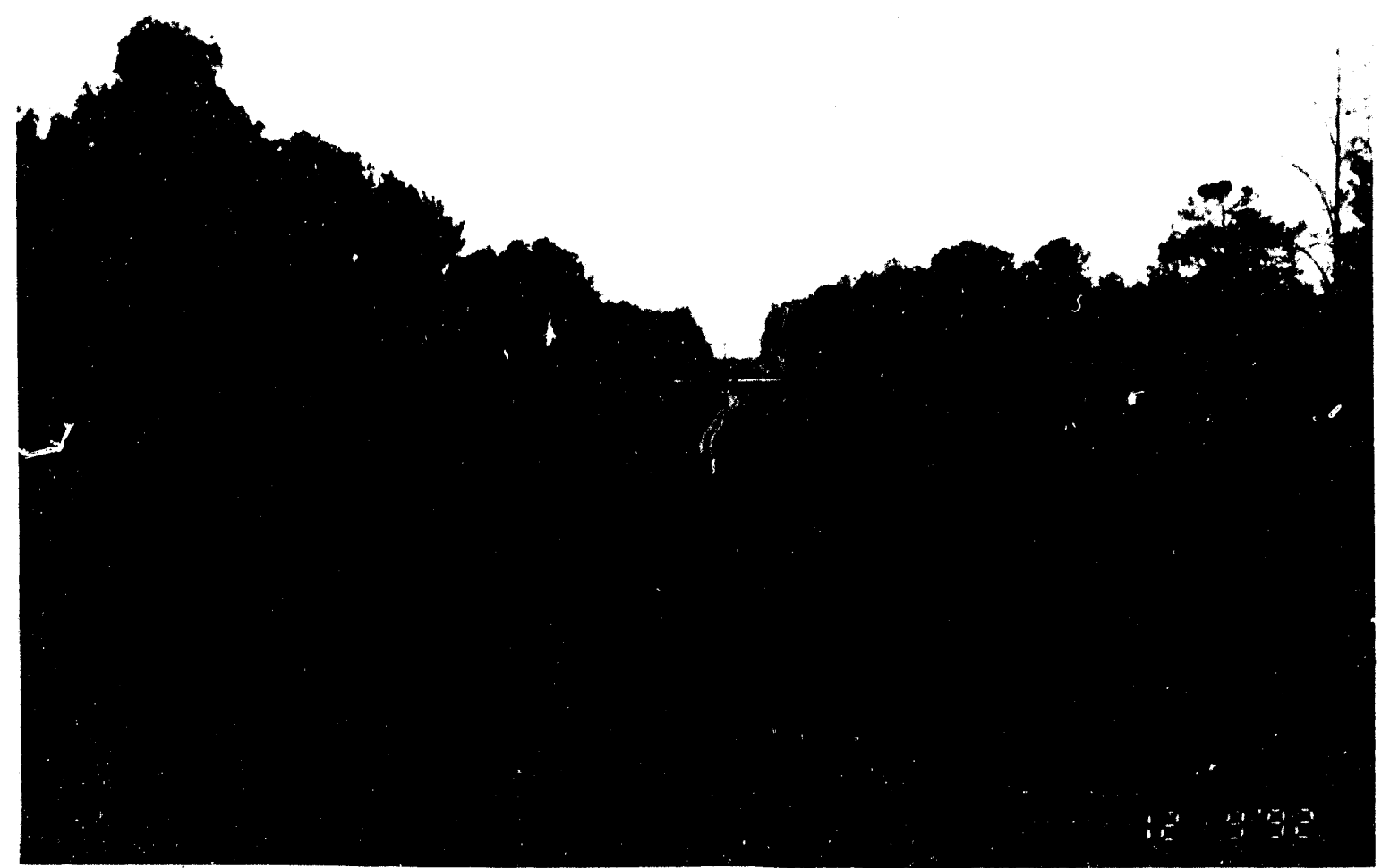

Figure 15. (View I) C/CS-Area trunk line route looking northwest where it will span Fourmile Branch.

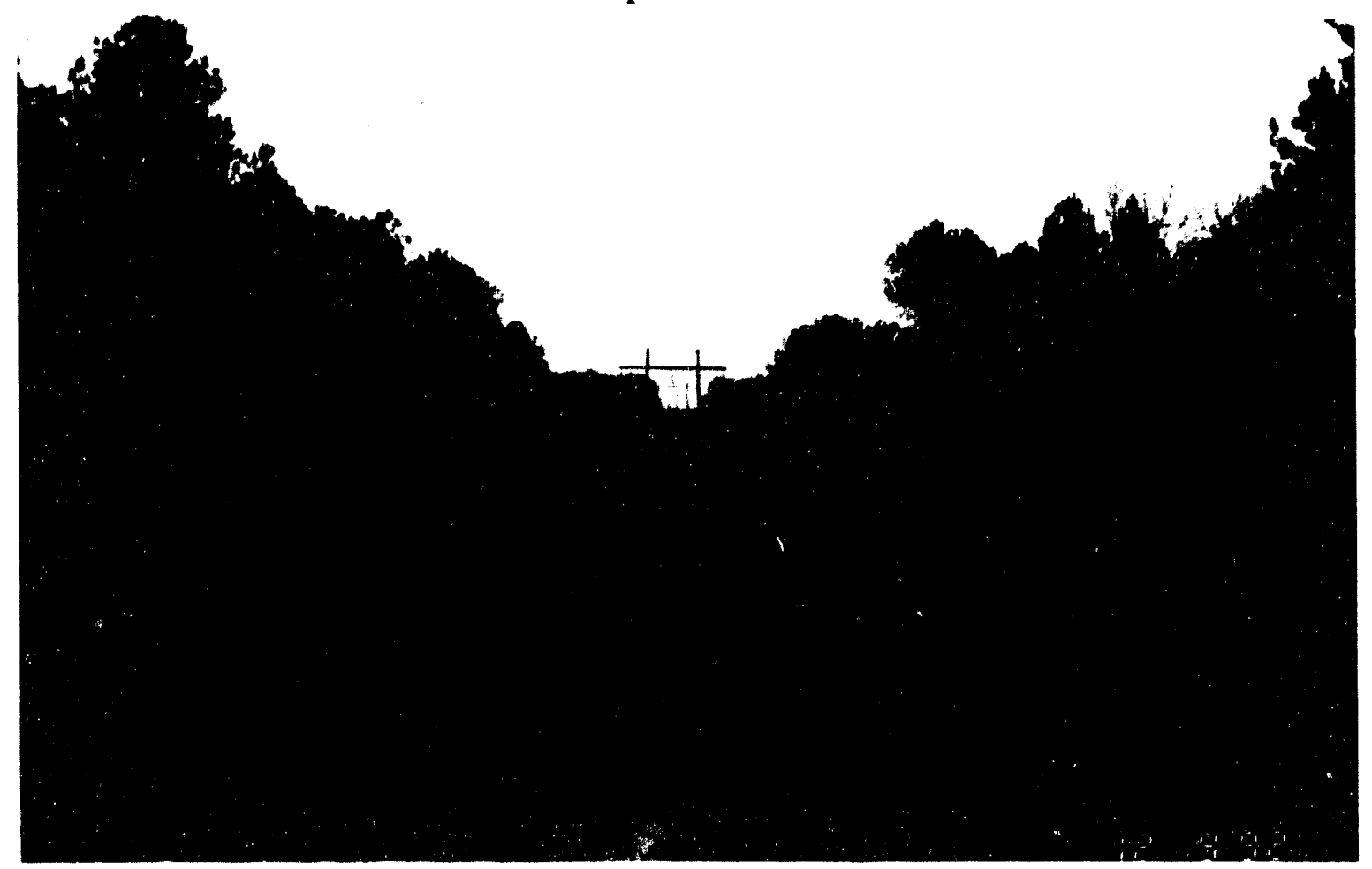

Figure 16. (View J) Trunk line route looking southeast along power line right-of-way with proposed six-acre tract to the left. 
would put trunk lines well within highway right-of-way limits. As a result of the usual activities associated with major road construction (i.e., machine grading and trenching for drainage ditches), trunk lines along existing rights-of-way have little potential for impacting sites. Recent soil surveys for the SRS classify areas that have been extensively affected by major land alteration, (e.g., borrow pits, roadways, parking lots) as Udorthents, or unidentifiable soils that have been moved or mixed by heavy machinery (Rogers 1990:34$36,79-80$ ). Soil surveys maps were consulted to detect the location of Udorthents along trunk line routes as a possible aid in determining the severity of disturbance. According to these maps, the most heavily disturbed areas, or location of Udorthents, was along Road C southeast of Upper Three Runs Creek (the A-Area route) and the Road E segment of the HArea route (Rogers 1990: soil map 15).

Synopsis of Results

Archaeological survey of the proposed Wastewater Facility project area commenced on April 27, 1992 and continued intermittently through July 6, 1993 for a total of 16 work days. All survey was conducted by a crew composed of two archaeologists. Because of the extended nature of the survey, the two person crew often consisted of different personnel. Field work included the excavation of 159 shovel tests and three $1 \times 2 \mathrm{~m}$ test units. Six archaeological sites were recorded in the project area prior to this survey. Three of the recorded sites (38AK145, 38AK419, 38AK436) could not be relocated despite substantial survey efforts in the alleged site locations. One recorded site (38AK92) had been subjected to archaeological testing during a survey project in 1992. The results indicated that cultural deposits were severely disturbed (Crass and Abel 1992). Pedestrian and subsurface survey was also undertaken along Burma Road in areas of high probability for cultural resources. However, no evidence for new sites was detected.

One new archaeological site (38AK465) was discovered within the six-acre footprint. The dearth of artifact content and variation precludes any research potential at 38AK465. The remaining two previously recorded archaeological sites (38AK415 and $38 \mathrm{AK} 417$ ) located along the trunk line route were revisited for evaluation. Although both sites have been disturbed by historic period activities, the sites exhibit sufficient content and integrity to yield information important to ongoing studies of prehistoric land-use in the Aiken Plateau. Thus, the SRARP recommends these sites as eligible for nomination to the NRHP, and further recommends that adverse impacts to these sites be mitigated through avoidance or data recovery.

Archaeological and environmental contexts for the project are provided in Chapter 2. Methods of survey are provided in Chapter 3, and the results of investigations are fully reported in Chapter 4. Finally, the results are evaluated in Chapter 5 to make recommendations about the significance of sites in the project area. 


\section{CHAPTER 2 \\ ARCHAEOLOGICAL AND ENVIRONMENTAL CONTEXTS}

Comprehensive reviews of the environment and culture-history of the Upper Coastal Plain are provided in the recent syntheses of archaeological investigations on the Savannah River Site (SRS) (Brooks and Crass 1991; Sassaman et al. 1990). This chapter is not intended to duplicate these works, but rather to provide a project-specific context for the design and implementation of survey strategy and as a foundation for evaluating the results of survey. The following environmental and cultural-historical summary is drawn from a recently published report documenting survey and testing of sites in the Fourmile Branch watershed (Sassaman and Gillam 1993).

\section{Environment and Prehistoric Settlement Patterns}

Situated in the Upper Coastal Plain of South Carolina, the SRS encompasses the watersheds of several streams that flow southwesterly into the Savannah River. The project area lies on the eastern margin of Fourmile Branch, one of the smaller tributaries within the SRS.

Ranging in elevation from 24-122 $\mathrm{m}(80-400 \mathrm{ft})$ above mean sea level (amsl), the physiography of the SRS is comprised of two major components: the Aiken Plateau and the alluvial terraces of the Savannah River (Figure 5). The Aiken Plateau is a dissected sandy plain situated between the Savannah and Congaree Rivers in the upper Coastal Plain of South Carolina. Its sandy sediments dominant the SRS landscape and range in elevation from 76-122 m (250 to $400 \mathrm{ft}$ ) amsl. The alluvial terraces of the Savannah River occur below the $76 \mathrm{~m}$ elevation level. The project area, for the most part, lies at the interface between the southern boundary of the Aiken Plateau and the northern limit of the oldest alluvial terrace.

Specific topography of the SRS is the combined result of structural elements, ancient marine processes and more recent fluvial dissection. The major channels of tributaries follow fault lines and marine features, but their numerous feeder streams in unconsolidated sediments lend a great deal of topographic relief to the upland sandhills. Such formations in the Aiken Plateau are particularly sharp along the margins of Upper Three Runs and Lower Three Runs creeks, the area's two largest tributaries. Exposures of quartz cobbles, orthoquartzite and low-grade "chert" are found in the steep cut banks of these streams. These resources were exploited prehistorically by groups that occupied nearby ridge nose sites during the Early and Middle Woodland periods (Sassaman 1991).

The oldest and highest fluvial terrace of the Savannah River $\left(\mathrm{T}_{2}\right)$ is also highly dissected, although its topographic relief is less severe than in the Aiken Plateau. Because $\mathrm{T}_{2}$ is the alluvial terrace of greatest elevation and age, many of its original alluvial features have been obscured through erosion and dissection. In short, the boundary between the Aiken Plateau and T2, where the Wastewater Facility lies, is indistinct. The project area can thus be characterized as part of the upland sandhills subprovince. We hasten to add, however, that the project area lies at the southern boundary of the uplands zone relative to the Savannah River. The lower terraces of the Savannah River are only six kilometers downstream, and the modern floodplain is only another six kilometers away.

Interfluvial ridges of the Aiken Plateau are characterized by relatively xeric vegetation dominated by pine (Shelford 1963:86-87). More mesic communities with 


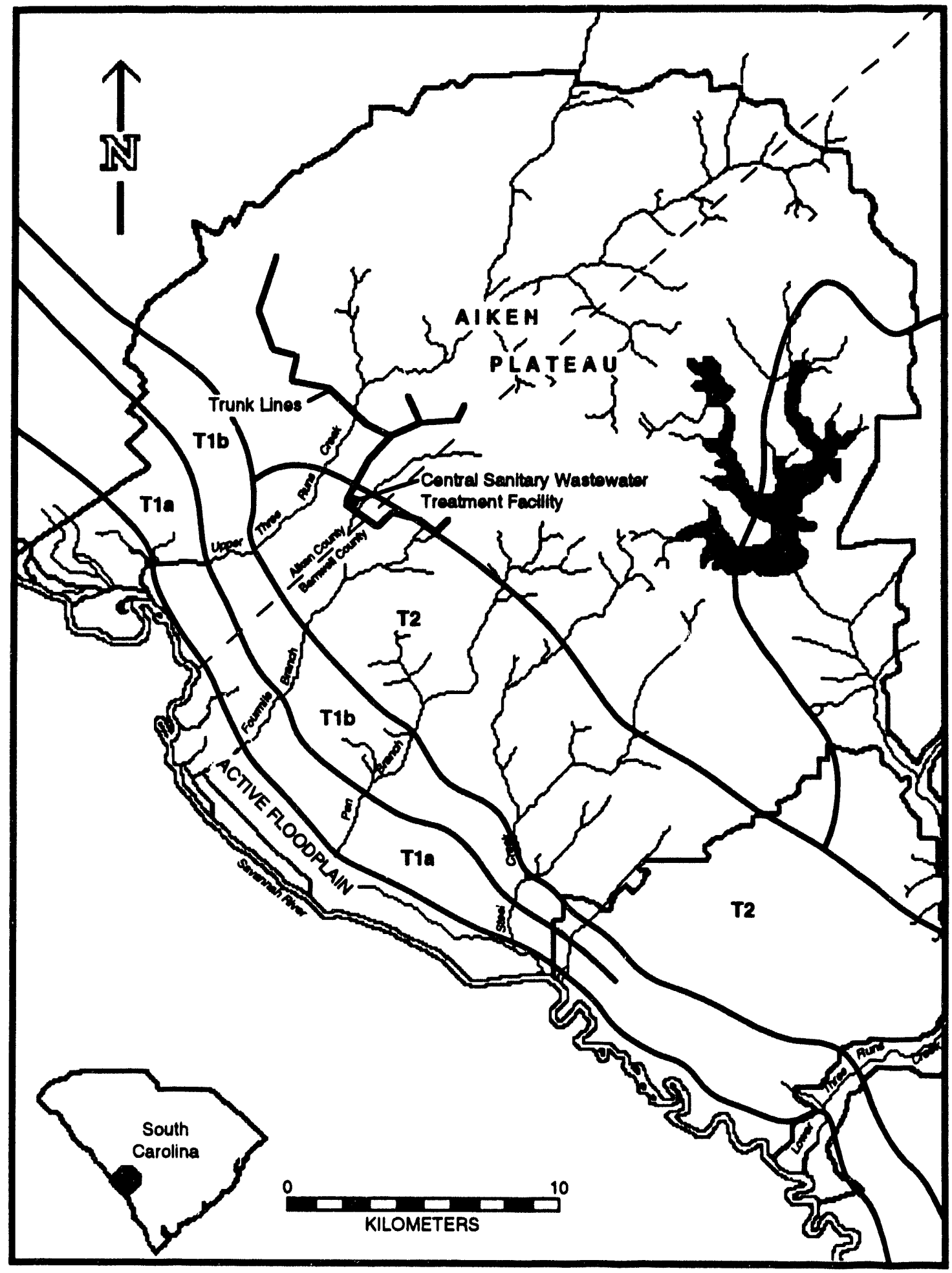

Figure 17. Physiography of the Savannah River Site area, showing location of project area. 
abundant oak are found on terminal ridge noses and slopes adjacent to active tributary stems (Barry 1980:97-116; Hanson et al. 1981:31). Major tributary streams in the Aiken Plateau, such as Upper Three Runs, have formed broad floodplains which support hydric flora in areas which are regularly flooded, as well as diverse mesic communities along floodplain margins and terraces. Thus, the topographis gradients of the Aiken Plateau created by tributary dissection support vegetative gradie its comprised of xeric, mesic and hydric communities (Hanson et al. 1981:28-36; Langley and Marter 1973; Whipple 1978; Whipple et al. 1981). Within the study area, this topographic gradient is not as marked as it is along Upper Three Runs Creek, nor is there as great a floodplain zone.

Like many other locations in the Aiken Plateau, the prehistoric food resource potential of the project area depended on its degree of fluvial dissection. Beginning with spring-fed tributary stems that dissect the sandhills, and moving downslope, resource potential improves with the gradient increase in moisture and soil productivity. Within this zone of dissection, oak mast is especially dense and productive. This resource, particularly the red oak group, was undoubtedly important to deer and humans alike. Noting this, Hanson proposed that the sandhills was targeted by humans for exploitation during the late fall and early winter-seasons during which deer and acom were most available (Hanson et al. 1981:42). Because water was the primary limiting factor over much of this zone, however, Hanson predicted that residential sites were positioned on the mesic terraces of tributaries, locations from which upland resource procurement trips were launched.

Archaeological investigations through the late 1980s on the SRS have tended to confirm Hanson's settlement model, as have numerous others surveys elsewhere in the Georgia and South Carolina sandhills province (e.g., Braley 1992; Braley and Price 1991, King and Braley 1992). Not until 1987, when the SRARP had the opportunity to excavate upland ridge nose sites along Upper Three Runs Creek, did it become apparent that resources typically regarded as "lithic and ceramic scatters" contained evidence for seasonal or multi-seasonal habitation by small groups (Sassaman 1987, 1989, 1991). Enabliing this revelation were large-scale hand-excavated blocks from which piece-plotted artifact data were generated to infer patterns of site use. Garnered from these data are evidence for structures, cooking hearths, refuse disposal areas and lithic workshops. In addition, analyses of lithic assemblages showed that by 3000 B.P., inhabitants of upland sites began to exploit local sources of low-grade raw material and to recycle the scavenged refuse of their transient predecessors (Sassaman and Brooks 1990).

Combined with the results of survey throughout the SRS, excavation results from sites in the Aiken Plateau provide sufficient data to generalize about changing patterns of upland site use. From this work we have found nothing to alter Hanson's model as it pertains to the Early and Middle Archaic Periods. Sites along the terraces of the Savannah River were preferred habitation loci, while upland sites in the Aiken Plateau appear to have been visited by hunters or other specialized task groups for only short periods of time.

By 4000 B.P., use of the Aiken Plateau included at least seasonal habitation at bluff margins overlooking tributaries and at the confluences of major stream stems. It is likely that riverine sites like Stallings Island and Lake Spring were occupied in the spring and summer by large groups. Furthermore, these groups apparently dispersed into the uplands for the fall and winter, provisioning their stays with large chert bifacial cores, soapstone cooking stones, and eventually pottery. Evidence for Late Archaic structures in the Aiken Plateau has not been found. However, recent excavations by Jerald Ledbetter (1991) at the headwaters of Brier Creek in Georgia has uncovered an isolated fourth millennium pithouse with an internal hearth. Presumably the cold weather structure for a small household, the pithouse may reflect the sorts of dispersed occupations expected for tributaries of the 
Savannah River. In the absence of organic preservation, the archaeological signature for pithouses would look much different than the evidence found for warm weather structures. Thus, it is possible that pithouses have been routinely overlooked in the Aiken Plateau.

Year-round occupation of the Aiken Plateau commenced sometime after 3000 B.P. Sites of this period are numerous and are distributed widely along bluff margins and at springheads. Proportionately fewer sites are located along the terraces of the Savannah River; those that have been investigated have not produced evidence for utilization that exceeds Aiken Plateau habitations in scale or duration. By all indications, Early Woodland occupation of the Aiken Plateau was perennial. This is not to say that settlement was sedentary for we have, as yet, found evidence for only warm weather occupations (Sassaman 1991). Instead, we suspect that groups moved to strategic locations within the Aiken Plateau, such as the confluences of major tributary stems, during the fall and winter to maximize access to the mesic vegetation of ridge slopes and stream terraces. The relative abundance of oak mast in these zones undoubtedly attracted deer into the area, and presumably species higher up on the food chain, especially humans. If, as in the previous period, pit houses were utilized during these seasons, we may again be missing the evidence for lack of preservation and the use of inappropriate excavation techniques.

Explanations for intensified upland site use remain a subject of considerable discussion. From his investigations of four sites on $T_{2}$ along Steel Creek, Brooks views fluvial responses to mid-Holocene sea level rise as a stimulus to increased upland resource potential (Brooks and Hanson 1987). He indicates that the onset of modern floodplain development in the Upper Coastal Plain of the Savannah River valley at ca. 4000 B.P. (Stevenson 1982) established the local fluvial base level that led to subsequent hydrologic changes in upland tributaries. This resulted in increased biomass of aquatic plant and animal resources as tributaries adjusted to a low-energy flow and mature floodplain regime. Importantly, these newly productive resources constituted spring and summer foods that were heretofore limited to mesic terrace zones below the Aiken Plateau. Given this new potential, along with attendant improvement in deer habitat, Brooks posits that upland utilization changed from fall resource procurement (i.e., deer and nuts) prior to ca. 4000 B.P., to seasonal habitation along upland tributaries during the Late Archaic period, leading eventually to multiseasonal habitation within upland zones by the Early Woodland period. Tests of these postulates with excavation data from four sites in the Steel Creek watershed were generally supportive (Brooks and Hanson 1987).

From a regional perspective, the results of recent excavations in the Upper Three Runs drainage bring to the fore an complementary model of intensified upland site use based on sociopolitical process. The regional picture reflects dramatic changes in the organization of populations that obviously had some bearing on the scale and duration of upland occupations. During the Late Archaic period (5000-3000 B.P.) subsistence production was at times organized at a multi-household or communal level at large riverine sites like Stallings Island (Claflin 1931). Interregional exchange, elaborate ceremonialism and other spheres of social interaction were both precedents and products of intensified production, putting demands on the labor of individuals for nonsubsistence funds. Utilization of upland sites during this time appears to have been seasonal, probably late fall and winter, and facilitated by group dispersion. Both the direct obligations of seasonal aggregation and the indirect costs of nonsubsistence production to support these formations put a check on the scale and duration of upland site use. Households were unable to sustain long-term occupations in the uplands not because of an inadequate food or water supply, for indeed paleoenvironmental indications show that by 4000 B.P., resource productivity in the uplands was on the rise. Rather, the limits to upland occupation were 
dictated by the high costs of social reproduction, that is, by the time and energy it took to participate in what appear to have been relatively complex hunter-gatherer societies.

But the centripetal processes that held Late Archaic society together engendered counteracting centrifugal forces. Throughout this period upland occupations provided the opportunity for households to disengage from obligations that placed excessive demands on individual labor. Apparently, households began to exercise this option in increasing numbers after 3500 B.P., a time when the long distance reverberations of interregional exchange may have placed additional demands on production. We suspect that the dissolution of the large Late Archaic societies was catalyzed by the fissioning of households into the uplands. Ironically, the seasonal utilization of upland sites during the Late Archaic period predisposed the environment for long-term use by Early Woodland households, so we might say that Late Archaic sociopolitical organization sowed the seeds of its own transformation. More to the point, Early Woodland populations were able to occupy the upland sandhills year-round simply because they assumed social formations that placed little demand on production beyond the subsistence needs of households. For these small-scale, loosely integrated groups, sandhills sites in the Aiken Plateau provided all of the resources for their limited needs.

Thus far, evidence used to construct and refine upland settlement models have come chiefly from sites along Upper Three Runs Creek, the largest tributary on the SRS. Fourmile Branch is small by comparison, particularly in its floodplain size, and has witnessed virtually no archaeological excavation. Based on survey data alone, it appears that the Fourmile Branch watershed contains a nonrandom subset of prehistoric sites. For instance, sites along Fourmile Branch are among the highest in artifact density but lowest in diversity, owed in large measure to high frequencies of lithic debitage (Sassaman et al. 1990:257). Local sources of lithic raw material have never been located in the drainage, though it appears that quarrying and core reduction were the primary activities taking place. Other lines of evidence support a model of limited site function. Few of the Fourmile Branch sites are multicomponent, and settlement clusters in the watershed are limited to relatively short periods (Sassaman et al. 1990:281-296). It is curious, for example, that during the Late Archaic period when settlement expanded throughout much of the upland sandhills, the Fourmile Branch watershed was virtually abandoned (Sassaman et al. 1990:299). Appreciable use of the watershed returned in the Middle Woodland period, but this paled in comparison to settlement in Upper Three Runs Creek and other tributaries.

Thus, it appears at face value that Fourmile Branch sites may not duplicate the evidence for intensive uplands occupation found among sites along the Upper Three Runs Creek. This is curious when one considers that small springheads and tributary stems within Fourmile support the same vegetation as Upper Three Run sites, while providing better access to the Savannah River and its floodplain microenvironments. Obviously, the differences in settlement patterns and land-use cannot be explained by environmental factors alone, and we must look at the larger regional contexts in which prehistoric cultures were created, maintained and transformed. Although these issues lie well beyond the scope of this project, the results of survey within the upland portion of Fourmile Branch provide an important comparison to upland surveys elsewhere, and help us to refine the models developed to explain the expanded use of upland sites after 4000 B.P.

Recently, intensive survey in the F/H project area (Sassaman and Gillam 1993) supplemented previous survey data on site locations on the west and north terrace margins of Fourmile Branch. Many sites were discovered along this margin in the early 1980s in anticipation of a cooling pond project that never came to pass (Martin et al. 1985). Land on either side of a $6.5 \mathrm{~km}$ stretch of Fourmile Branch was surveyed up to the $210 \mathrm{ft}$ amsl 
elevation level. The elevation limits precluded extensive coverage of the bluffs along the east margin, but thorough coverage of the west margin terrace produced evidence for over a dozen sites, nearly all with Middle and Late Woodland components. A closer look at the bluff margins of Fourmile Branch occurred during survey of the Site R Sanitary Landfill (Sassaman et al. 1992). Several small sites with a variety of prehistoric components were found along a ridge nose overlooking Fourmile Branch. Density at these sites was not great, but they contained sufficient diversity to reflect small-scale habitation functions at least during the Woodland period.

How sites on either side of Fourmile Branch compare in size, density, and component representation is currently unknown. As pointed out by Sassaman and Gillam (1993:17), microtopographic variation in the Aiken Plateau may be an important consideration in understanding site locational variability. This issue is relevant at the local scale for its potential effects on site selection on either side of Fourmile Branch. It is likewise relevant at a larger scale regarding habitation in the Fourmile Branch watershed, as opposed to the Upper Three Runs Creek watershed. At an even larger scale, microtopographic considerations have relevance to variables such as coresident group size and group spacing that reflect sociopolitical organization.

\section{Late Historic Period Settlement}

The last few centuries of human occupation in the SRS area ran a course that in some respects paralleled prehistoric settlement. Early in the historic occupation of the SRS area, during the Colonial Period of the mid- to late eighteenth centuries, settlements were concentrated along the terraces overlooking the Savannah River and its major tributaries (Brooks and Crass 1991). These trends continued through the Antebellum Period of the nineteenth century, with gradual increases in the number of settlements and occupation of upland locations. Settlement in the SRS area burgeoned in the Postbellum/Modern Period, when there was a greater tendency for sites to be located in less desirable interriverine portions of the Aiken Plateau.

The settlement changes documented by Brooks and Crass (199:) are explained as a response to population increase, changing economic organization and technological innovation. The riverine orientation of early settlement was strongly influenced by transportation options (i.e. the watercourses) and the demand for productive agricultural land. Because farming and other agricultural activities prior to the mid-nineteenth century remained small in scale, residences were located next to fields, hence the direct correlation between soils of riverine and tributary terraces and early historic settlements.

The increased use of upland sandhilis locations after the Civil War coincided with agricultural intensification, including monocropping, and development of the tenant land tenure system. Prime farmiand along the Savannah River and its tributaries continued to be used, but agricultural intensification led to increased use of less-productive land in the uplands. These locations were generally occupied by renters and sharecroppers who had little option for more productive land, nor the need or power to command hubs of transportation and informatior. In addition, the increased use of wells abated the need to locate residences near sources of running water. The result is that by the early twentieth century, many interriverine areas of the SRS previously ignored or underutilized were densely occupied by tenant farmers. Aerial photographs and maps dating to the 1940s and early 1950s document over 6000 late historic structures within the present-day boundaries of the SRS; the vast majority of these are located in interfluvial areas of the upland sandhills (Brooks and Crass 1991:79). 
Thus, an increase in the use of upland sites during the historic period parallels the patterns observed during late prehistory. These patterns diverge, however, when we consider the specific locations of late historic period residences within the uplands. While prehistoric sites remained tied to locations of running water, late historic residences are often located $500 \mathrm{~m}$ or more from streams (Brooks and Crass 1991:64). In essence, these late historic sites are the only potentially significant archaeological resources located in the interriverine portions of the upland sandhills. As noted earlier, these sites are typically visible on aerial photographs of the SRS, and records of residences occupied when the Atomic Energy Commission acquired the land in the early 1950s are maintained by the Department of Energy-Savannah River Field Office.

Tenant farms throughout the Southeastern United States continue to attract archaeological interest. The SRARP recently completed fieldwork to mitigate the adverse affects of proposed construction on three tenant/yeoman farms in the upland sandhills. Research efforts center on a series of methodological and theoretical propositions that will improve our ability to test and evaluate these ubiquitous resources. The results of this work are not yet available, though it appears that the significance of tenant sites will hinge on the ability to isolate discrete assemblages within sites that are representative of different activities, and to relate variation among these to social, economic and political dimensions of consumer behavior. Research agendas from work elsewhere will no doubt be useful in evaluating tenant farms on the SRS. Irrespective of these, the assessment of research potential must first take into consideration information from land acquisition records and other documentation to identify unique or particularly interesting aspects of specific sites, as well as archaeological integrity as determined through survey and testing. 


\section{CHAPTER 3 \\ SURVEY METHODS}

Following established procedures of the SRARP (1990:7-17), prior to initiating the field survey, a documentary review was conducted of the SRARP site files, previous survey reports, and mid-twentieth century aerial photographs (United States Atomic Energy Commission Aerial Photographs 1951) to identify cultural resources in the proposed Wastewater Facility project area. No existing sites were recorded for the six-acre tract, although the location of one late historic period house was observed on the 1951 aerial photograph of the area. Six previously recorded sites (38AK92, 38AK145, 38AK415, 38AK417, 38AK419, 38AK436) were noted in proximity to trunk line routes. This chapter therefore begins with a summary of prior work in the vicinity of the six-acre tract and along trunk line routes. This information is used in conjunction with archaeological sensitivity data for the SRS (SRARP 1989a:39-53) to develop a survey design, which along with the specific field methods employed in this project, comprise the rest of this chapter.

\section{Previous Survey}

During the twenty years of archaeological work on the SRS, seven surveys have occurred in and around the Wastewater Facility project area. Figure 18 shows the areas covered during six of the surveys. One other project, the SRS-wide inventory, was designed to investigate 40-percent of the SRS including large tracts along Fourmile Branch. Figure 19 depicts the locations of several sites discovered during these survey efforts, six of which were targeted for archaeological investigation during the Wastewater Facility project. The nature of these previous surveys involved long-term management planning, compliance related activities, and research projects. The design and implementation of each of these survey efforts is briefly reviewed in this section.

A transect reconnaissance of the entire Savannah River Site (SRS) was undertaken between 1973 and 1977 by staff of the South Carolina Institute of Archaeology and Anthropology (Hanson et al. 1978; Sassaman et al. 1990: 67-69, Figure 13). The reconnaissance entailed pedestrian survey of rights-of-way, including roads, railroad beds, power lines, and firebreaks, but no subsurface testing. As Figure 18 shows, much of the Wastewater Facility trunk line route was previously surveyed during this initial SRS project. In fact, the only portions not surveyed were those inside restricted areas and the segment along the power line right-of-way between Road C and Road D. Two of the 309 archaeological sites discovered during this early SRS survey are situated along the trunk line route: 38AK92 is located along the north side of Road C near the confluence of Tim's Branch and Upper Three Runs Creek and 38AK145 is located along Road C on the northeastern margin of Upper Three Runs Creek (Figure 19).

Subsequent survey in and around the Wastewater Facility project area along Fourmile Branch was undertaken as part of the SRS-wide inventory (Sassaman et al. 1990:69-76). Designed as a stratified, random sample, the survey entailed 40-percent coverage of the entire SRS for the purposes of developing a long-term management plan. To facilitate representative coverage in all microenvironments, the SRS was stratified by watershed and Patrol Index Units (PIUs). Each 4000x4000 ft PIU was coded for landform and stream rank to derive sampling strata, and from these a 40-percent sample was selected for survey. Fourmile Branch was the first watershed completed in the SRSwide survey. The results of this pilot project led to refinements in survey design (Sassaman et al. 1990:73). Among them was a reduction in the size of strata by subdividing PIUs into $2000 \times 2000 \mathrm{ft}$ quadrants. 


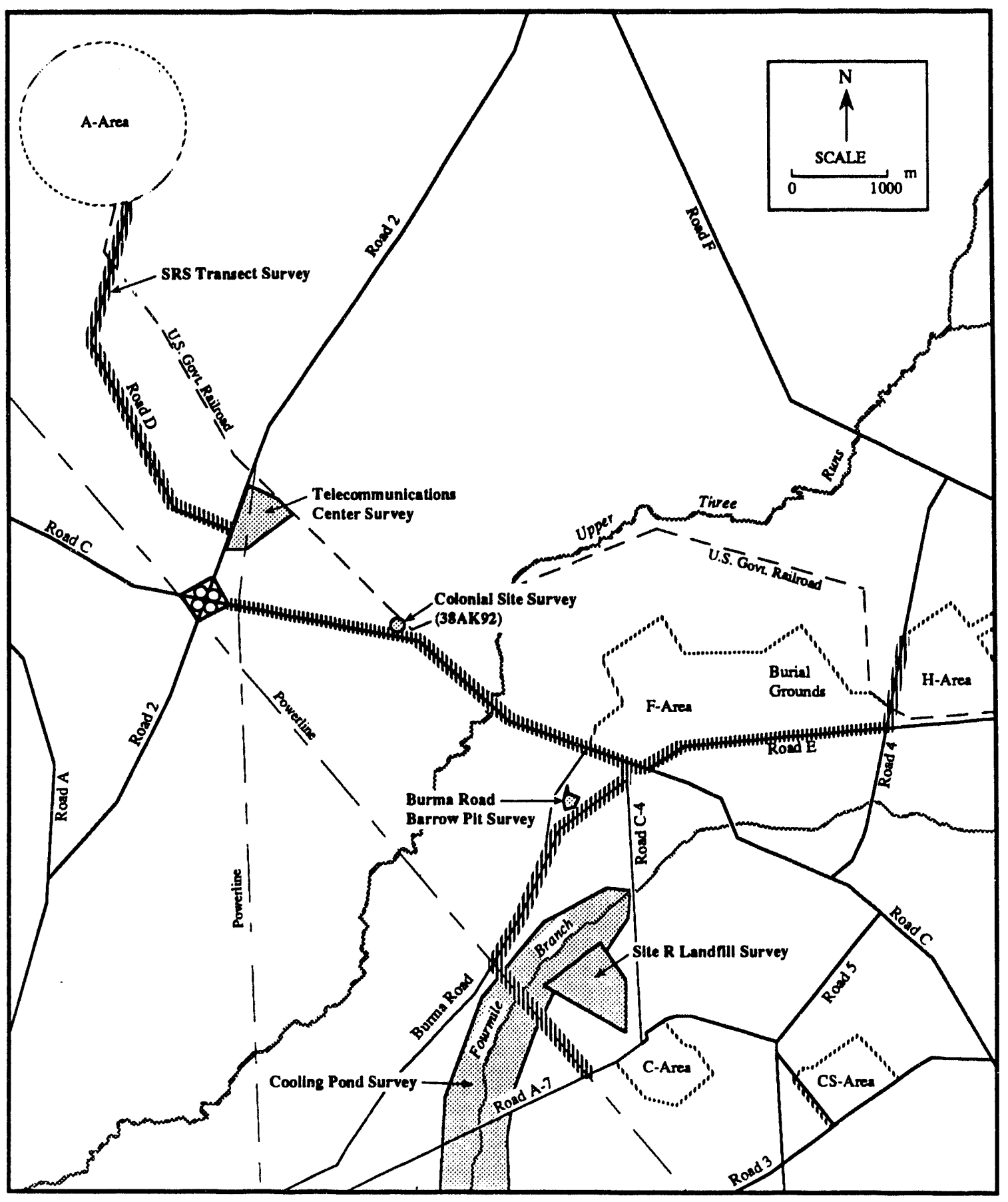

Figure 18. Locations of previous. archaeological surveys' in and around the Wastewater Facility project area. 


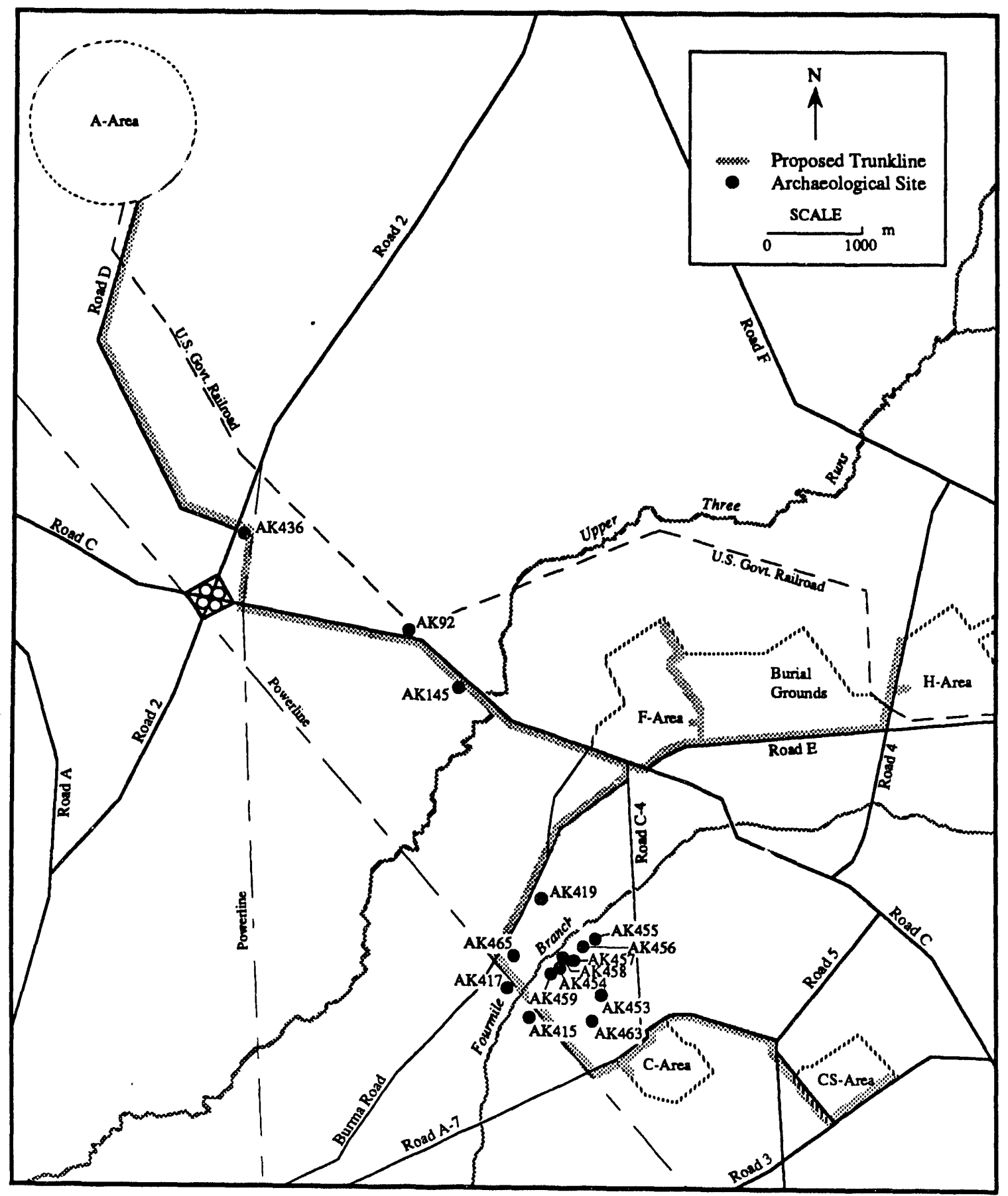

Figure 19. Locations of previously recorded and new sites in and around the Wastewater Facility project area. 
The PIU quadrants in and around the project area are depicted in Figure 20. Two PIUs (J-11, K-10) were randomly selected for survey in the 1978-79 survey of Fourmile Branch. No new sites were located in any of these units. Field methods consisted chiefly of pedestrian survey in high visibility areas, with rake and shovel tests supplementing surface inspection in some areas. As the results of subsequent surveys demonstrate (Martin et al. 1985; Sassaman et al. 1992), the SRS-wide survey methods were often inadequate to locate buried prehistoric deposits.

Intensive survey along Fourmile Branch was completed during 1984 in response to a proposed cooling pond for regulating thermal effluent (Martin et al. 1985). The proposed floodpool for Fourmile Branch included the Wastewater Facility six-acre tract, but it only implicated land lower than $210 \mathrm{ft}$ amsl. The survey nonetheless included some investigation outside the impact zone. Sites recorded during this project include 38AK415, 38 AK 417, and 38AK419, all of which are located along trunk line routes. Subsurface techniques were used to locate and define these sites, but details concerning sampling intervals and location of shovel test transects were not provided in the 1985 report.

The subsurface site discovery techniques used in the Fourmile Cooling Pond project proved to be inadequate when a survey for the proposed 140-acre Site R Landfill was conducted in 1991-92 (Sassaman et al. 1992). During this project, intensive testing occurred along the bluff margins and adjacent uplands of Fourmile Branch directly opposite the Wastewater Facility six-acre tract. Fieldwork, consisting of shovel tests pits dug at 30 $m$ intervals along transects and at judgmental locations, resulted in the discovery of seven new prehistoric sites. Six of these (38AK454, 38AK455, 38AK456, 38AK457,

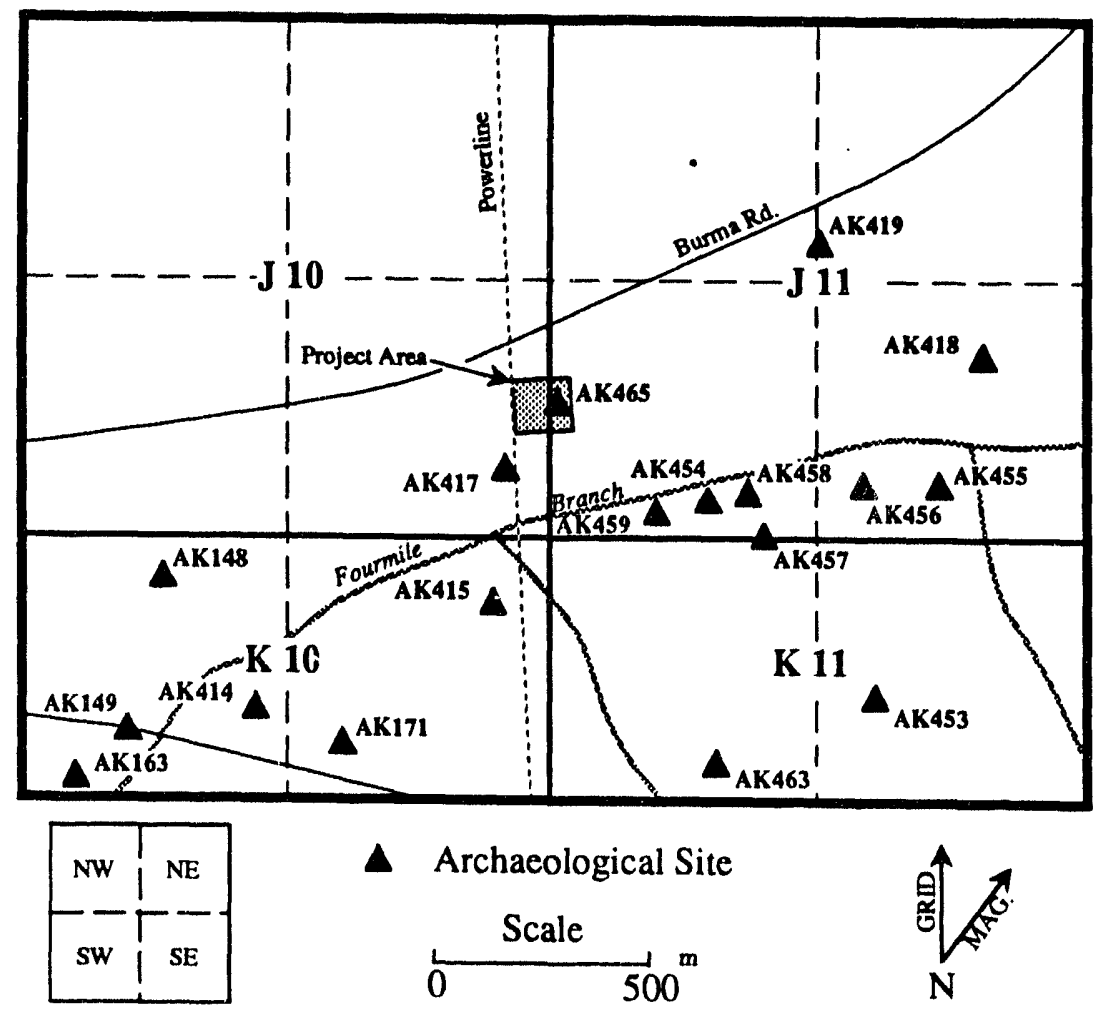

Figure 20. Patrol Index Unit quadrants in and around the Wastewater Facility project area along Fourmile Branch. 
38AK458, 38AK459) were multicomponent sites located on small ridge nose landforms overlooking the floodplain. The seventh site (38AK463), which consisted of a small concentration of chert debitage, was situated on the upland ridge. Additionally, one midtwentieth century farmstead (38AK453) was also located on the upland ridge top.

Finally, two small Site-Use surveys were conducted in the vicinity of the Wastewater Facility trunk line routes. In April of 1989, survey of the proposed SRS Telecommunication Center project area along Road 2 was conducted by SRARP personnel in response to SR-88 Site Use Application 89-48-C (SRARP 1989b:3). The Telecommunication Center footprint basically conformed to a 42-acre parcel (Stand 1 of Timber Compartment 13) that had been logged just prior to the survey. During surface reconnaissance of the clearcut, only one artifact, a Late Archaic stemmed hafted biface, was recovered. This isolated find was designated 38AK436. Due to the lack of other cultural material and the apparent absence of surface and subsurface integrity, the SRARP recommended no further action. Subsequently, another locale was selected for the Telecommunication Facility, thus allowing further testing at 38AK436 during the trunk line route survey.

During March of 1992, SRARP personnel responded to SR-88 Site Use Application 85-01-O Amendment No. 1 by investigating the proposed expansion of an existing borrow pit on Burma Road (SRARP 1992:14). The 5.6 acres (2.3 ha) comprising the project area are in an interriverine setting at almost equal distances from Upper Three Runs $(1000 \mathrm{~m})$ and Fourmile Branch $(1300 \mathrm{~m})$. The vegetation consisted of a stand of mixed hardwoods and pines resulting in poor ground surface visibility. However, a freshly plowed firebreak bisecting the project area served as the survey locus. No artifacts were observed during pedestrian coverage of the firebreak indicating an absence of cultural material in the area. These results were later substantiated during the trunk line survey along Burma Road (see Field Methods section).

Recently, a research project was initiated to investigate a number of previously recorded early historic settlements along the terraces of major drainages on the SRS (Crass and Abel 1992). In particular, this project targeted sites with the potential to yield evidence of Colonial period occupation. Among the sites tested during this survey was 38AK92 located along Road C at the confluence of Tim's Branch and Upper Three Runs Creek. Substantial testing efforts at the site, however, revealed that past construction activities have resulted in severe disturbance to cultural deposits. Further details regarding archaeological work at 38AK92 are provided in Chapter 4.

An inventory of the survey units, survey statuses, and recorded sites within the vicinity of the Wastewater Facility six acre-tract and adjacent trunk line routes is provided in Table 1. Judging by the number of survey projects conducted, it seems that survey has been quite intensive in the PIU Quadrants listed below and depicted in Figure 20. However, it is noteworthy to point out that no sites were found in the area during the random quadrant survey of the SRS-Wide inventory. A number of factors account for this lack of sites. For one, the Fourmile Branch watershed was the first to be surveyed for the SRS-Wide inventory, so experience in finding buried sites was minimal. The techniques of site discovery were inadequate (i.e. rake tests) and much more subsurface testing was needed. Moreover, the SRS transect reconnaissance project consisted solely of pedestrian survey along right-of-ways. Although four sites were recorded during this effort for the area shown in Figure 20, deeply buried deposits were most likely missed. Subsequent special project or Site-Use surveys increasingly succeeded in locating buried sites by employing close-interval and numerous judgmental shovel tests. In particular, the Site $\mathbf{R}$ Landfill project results show that site densities in the Fourmile tributary perhaps rival those 
Table 1. Survey and Site Information for Patrol Index Unit Quadrants (PIU Quads) in and around the Wastewater Facility Project Area along Fourmile Branch.

\begin{tabular}{|c|c|c|c|}
\hline PIU Ouad & Survey Status & Project(s) & Sites Reconded \\
\hline $\begin{array}{l}\mathrm{J}-10 \mathrm{NW} \\
\mathrm{J}-10 \mathrm{NE} \\
\mathrm{J}-10 \mathrm{SE}\end{array}$ & $\begin{array}{l}\text { Unsurveyed } \\
\text { Unsurveyed } \\
\text { Transect } \\
\text { Special }\end{array}$ & $\begin{array}{l}\text { SRS Reconnaissance } \\
\text { Cooling Pond }\end{array}$ & 38 AK417 \\
\hline $\begin{array}{l}\text { J-10 SW } \\
\text { J-11 NW } \\
\text { J-11 NE }\end{array}$ & $\begin{array}{l}\text { Unsurveyed } \\
\text { Transect } \\
\text { Random }\end{array}$ & $\begin{array}{l}\text { SRS Reconnaissance } \\
\text { SRS-Wide }\end{array}$ & \\
\hline J-11 SE & $\begin{array}{l}\text { Special } \\
\text { Random }\end{array}$ & $\begin{array}{l}\text { Cooling Pond } \\
\text { SRS-Wide }\end{array}$ & 38AK419 \\
\hline J-11 SW & $\begin{array}{l}\text { Special } \\
\text { Special } \\
\text { Special }\end{array}$ & $\begin{array}{l}\text { Cooling Pond } \\
\text { Site R Landfill } \\
\text { Site R Landfill }\end{array}$ & $\begin{array}{l}\text { 38AK418 } \\
\text { 38AK455, 38AK456, } \\
\text { 38AK454, 38AK457, 38AK458, } \\
\text { 38AK459 }\end{array}$ \\
\hline K-10 NW & $\begin{array}{l}\text { Transect } \\
\text { Special }\end{array}$ & $\begin{array}{l}\text { SRS Reconnaissance } \\
\text { Cooling Pond }\end{array}$ & $\begin{array}{l}\text { 38AK148, 38AK149, 38AK163 } \\
\text { 38AK414 }\end{array}$ \\
\hline $\mathrm{K}-10 \mathrm{NE}$ & $\begin{array}{l}\text { Transect } \\
\text { Special }\end{array}$ & $\begin{array}{l}\text { SRS Reconnaissance } \\
\text { Cooling Pond }\end{array}$ & $\begin{array}{l}\text { 38AK171 } \\
\text { 38AK415 }\end{array}$ \\
\hline $\begin{array}{l}\mathrm{K}-11 \mathrm{NW} \\
\mathrm{K}-11 \mathrm{NE}\end{array}$ & $\begin{array}{l}\text { Special } \\
\text { Special }\end{array}$ & $\begin{array}{l}\text { Site R Landfill } \\
\text { Site R Landfill }\end{array}$ & $\begin{array}{l}38 \mathrm{AK} 463 \\
\text { 38AK453 }\end{array}$ \\
\hline
\end{tabular}

along such drainages as Upper Three Runs, but sites may be comparatively smaller, contain less diverse assemblages, and date to later temporal periods in the former context. As discussed in Chapter 2, the Fourmile Branch sites are dominated by Middle and Late Woodland components, with proportionately fewer Late Archaic and Early Woodland components than found along Upper Three Runs Creek. The results of survey for the Wastewater Facility project area in conjunction with site data generated from the F/H Area survey along Fourmile Branch (Sassaman and Gillam 1993) can be used to further examine this seeming pattem of differential settlement.

\section{Survey Design}

The meager inventory of intensively tested sites in the vicinity of the Wastewater Facility project area as inventoried in Table 1 provides little opportunity to make generalizations about prehistoric land-use practices for the purposes of survey design. However, as part of the larger SRS inventory of sites, the small sample reflects the tendency for habitation areas to be situated near appreciable sources of running water. Data on site distribution and assemblage content were used to quantify this locational relationship in a model of archaeological sensitivity (SRARP 1989a:39-53). Archaeological sensitivity refers to the potential a given area has to contain sites with multiple components, and dense and diverse artifact assemblages. In short, the data show that sites indicative of long-term and/or repeated occupation are located within $400 \mathrm{~m}$ of streams Rank 3 or greater. Lesser sites are also located in this zone, but extend much farther away from major streams into upland areas along small tributaries and at springheads. Sites generally referred to as "lithic scatters" (i.e., assemblages consisting of a few nondiagnostic lithic artifacts, usually flakes) assume a seemingly random distribution across the landscape and are found as much as $1700 \mathrm{~m}$ away from a source of running water. Interfluvial land use therefore appears to have been transient or specialized. 
SRS Archaeological Sensitivity Zones were calculated from a locational analysis of oyer 450 prehistoric sites for which adequate documentation about content was available. Sensitivity Zones range in value form 1 to 3 . Zone 1 consists of all lands within $400 \mathrm{~m}$ of streams Rank 3 or greater; Zone 2 is all land $401-800 \mathrm{~m}$ from streams Rank 3 or greater and all lands within $400 \mathrm{~m}$ of streams less than Rank 3; Zone 3 is all other lands with the exception of modern swamps and floodplains, which are routinely coded as " $\emptyset$ " to denote inaccessible areas.

The Sensitivity Zones in the vicinity of the Wastewater Facility six-acre tract are depicted in Figure 21. The six-acre parcel is completely within Zone 1, so there is a high probability for prehistoric sites. As is apparent from the number of recorded sites along Fourmile Branch, Zone 1 has undergone rather extensive previous survey. As noted above, the six-acre tract and adjacent area was investigated during the SRS-wide survey (Sassaman et al. 1990:69-76), the SRS transect reconnaissance project (Hanson et al. 1978) and the Fourmile Cooling Pond survey (Martin et al. 1985). However, the methods employed during these surveys were often inadequate to locate buried prehistoric deposits. Therefore, intensive subsurface testing was conducted within the six-acre project footprint.

Sensitivity Zone values for the Wastewater Facility trunk line routes are presented in Table 2. Except for the Burial Ground route, these values show that the trunk lines traverse all sensitivity zones with the greatest potential for prehistoric sites along the line leading to H-Area, particularly the stretch along Burma Road. As indicated earlier, virtually all routes were previously surveyed, resulting in the discovery of six sites. Because of previous survey efforts, sensitivity values along trunk lines were, for the most part, inconsequential to survey design. Instead, survey along trunk lines was designed to relocate and evaluate existing sites. Additional subsurface testing was conducted along the

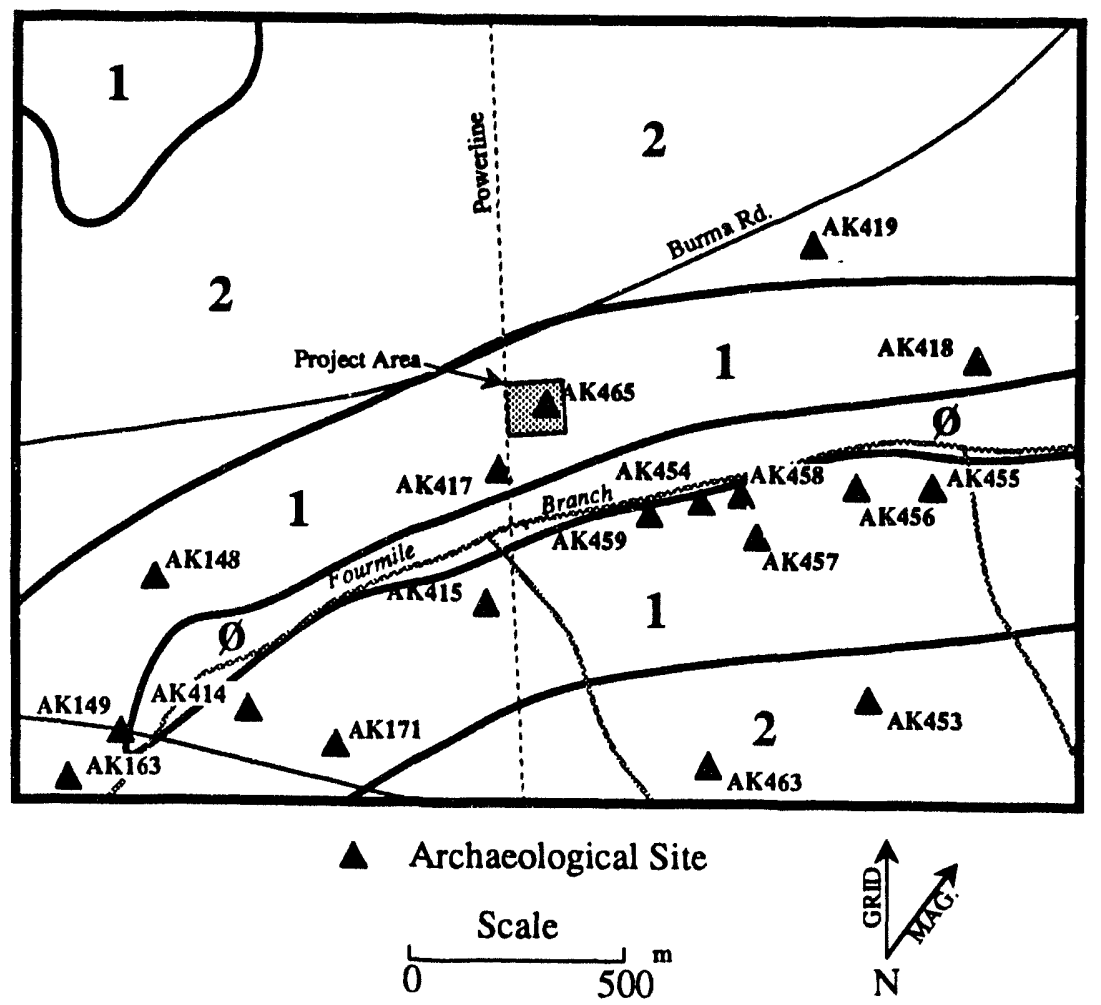

Figure 21. Sensitivity zones in the vicinity of the Wastewater Facility six-acre tract. 
Table 2. Archaeological Sensitivity Values for Wastewater Facility Trunk Line Routes.

\begin{tabular}{|c|c|c|c|c|c|c|}
\hline & $\begin{array}{r}\text { Li in } \\
\text { Zone } 1\end{array}$ & $\begin{array}{l}\text { EX P } \\
\text { Zone } 2\end{array}$ & $\begin{array}{l}\text { (apprx } \\
\text { Zone } 3\end{array}$ & $\begin{array}{l}\text { km) } \\
\text { Sum }\end{array}$ & $\begin{array}{l}\text { Woighted } \\
\text { Sum }\end{array}$ & $\begin{array}{c}\text { Mean } \\
\text { Sensitivity }\end{array}$ \\
\hline $\begin{array}{l}\text { A-Area Route } \\
\text { C-Area Route } \\
\text { H-Area Route } \\
\text { Burial Ground Route }\end{array}$ & $\begin{array}{l}1.9 \\
0.6 \\
3.1 \\
0.0\end{array}$ & $\begin{array}{l}4.4 \\
4.1 \\
4.7 \\
1.1\end{array}$ & $\begin{array}{l}3.4 \\
0.9 \\
2.5 \\
0.1\end{array}$ & $\begin{array}{r}9.7 \\
5.6 \\
10.3 \\
1.2\end{array}$ & $\begin{array}{r}20.9 \\
11.5 \\
20.0 \\
2.5\end{array}$ & $\begin{array}{l}2.15 \\
2.05 \\
1.94 \\
2.08\end{array}$ \\
\hline Total & 5.6 & 14.3 & 6.9 & 26.8 & 54.9 & 2.05 \\
\hline
\end{tabular}

Burma Road trunk line route because of the potential for archaeological remains. Improvements to Burma Road, a gravelled thoroughfare, had not been as extensive as those along paved highways thus allowing for the possibility that buried prehistoric deposits were still preserved.

\section{Field Methods}

Field survey for the Wastewater Facility project area was structured and implemented in three stages: (1) survey of the six-acre tract; (2) survey of existing sites along the trunk line routes, and (3) survey along portions of Burma Road with archaeological potential. Standard survey methods established in January of 1990 (SRARP 1990:15-16) were followed during fieldwork. Shovel tests, measuring $35 \times 35 \mathrm{~cm}$, were excavated to a depth of $80 \mathrm{~cm}$ BS or until sterile, sandy-clay substrate was encountered. All soil was passed through 0.25 in $(0.64 \mathrm{~cm})$ wire mesh, and artifacts were collected and bagged according to shovel test number and provenience. The location, contents, and depth of each shovel test were recorded on SRARP Shovel Test Forms.

Further site testing at previously recorded sites 38AK415 and 38AK417 involved the excavation of three $1 \times 2 \mathrm{~m}$ test units. All soil was screened through 0.25 in $(0.64 \mathrm{~cm})$ wire mesh, and artifacts were collected and bagged by test unit level. The contents, depth, and other relevant information concerning each level were recorded on SRARP Test Unit Forms. Upon completion of each test unit, scaled drawings and photographs were made of one profile. Finally, black and white photographs were taken of each site and existing site forms and field maps were updated.

Survey of the Proposed Wastewater Facility Six-Acre Tract. Intensive archaeological survey of the six-acre tract was accomplished by pedestrian coverage of the entire area and subsurface testing along seven transects that corresponded to transit survey lines cut by SRS engineers (Figure 22). Fieldwork was initiated with a search for evidence of an early to mid-twentieth century homesite, apparently a small tenant house located in an agricultural field, that was detected on the 1951 aerial photographs. This structure stood in what is now the northeast section of the project footprint. No standing architecture was observed in this location and shovel testing did not reveal any subsurface remains indicating that the house was completely razed, a common practice during construction of the SRS in the early 1950s.

Following the historic site reconnaissance, survey for prehistoric sites proceeded. A thick mat of pine needle detritus obscured all surface visibility with the exception of two freshly plowed firebreaks (Transects 1 and 2) along the northwestern and southeastern edges of the project area. Firebreak Transect 1, located just north of the project footprint, paralleled the steamline along Burma Road and continued across a clearcut timber stand adjacent to the six-acre tract. No artifacts were observed along the entire length of the 


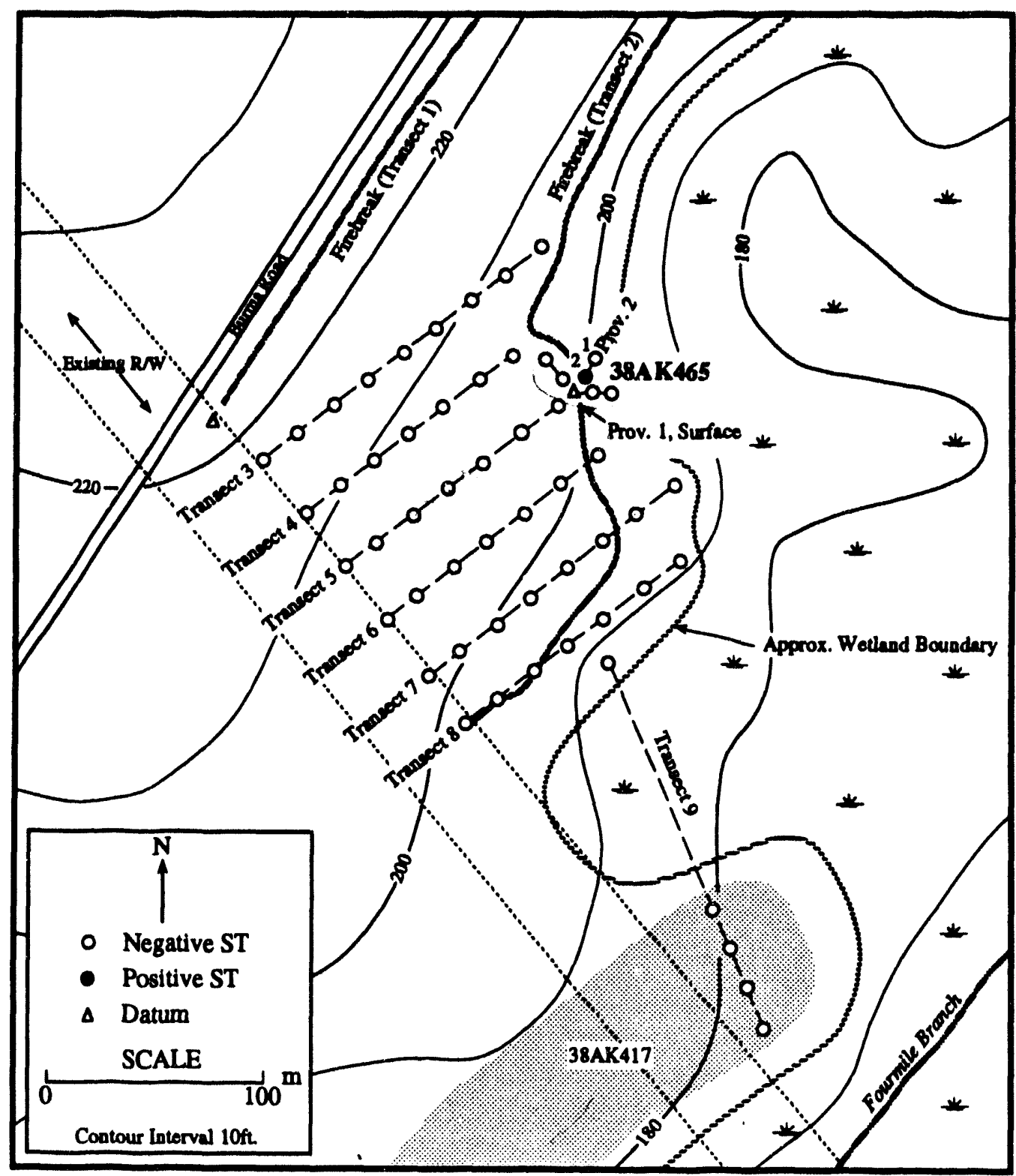

Figure 22. Map of Wastewater Facility six-acre tract showing location of firebreak and shovel test transects.

firebreak. However, in firebreak Transect 2, which closely followed the floodplain margin, three chert flakes were discovered. Systematic shovel testing was employed to investigate the nature of the lithic scatter, which was subsequently designated 38AK465. Further information concerning the site is provided in Chapter 4.

Finally, the survey was completed by excavating shovel tests excavated along the seven transit lines (Transects 3-9) established by SRS engineers. Shovel test Transects 3-8 followed six transit lines that were spaced $30 \mathrm{~m}$ apart and oriented 50 degrees east of north. 
Transect 9 followed a short pipe line route oriented in a southeastern direction. This transect originated near the southern project boundary and ended after crossing a small ridge nose on which the previously recorded site 38AK417 was located. Shovel tests were dug at $20 \mathrm{~m}$ intervals along each of the seven transects to the floodplain margin. A total of 50 shovel tests was excavated in this way and all were negative.

Survey of the Proposed Wastewater Facility Trunk Line Routes. The second stage of fieldwork consisted of surface and subsurface investigations at various survey loci along the trunk line routes associated with the Wastewater Facility. These routes are shown in Figure 23. As explained earlier, almost all the trunk line routes had been subjected to previous survey during the initial SRS transect reconnaissance (Hanson et al. 1978) (Figure 18). Therefore, the trunk line survey consisted of subsurface testing at locations of previously recorded sites or in areas of high probability for cultural resources along Burma Road. Five survey loci, shown in Figure 23, were targeted for investigation. In addition, shovel tests and test units were also employed to obtain further information (site size, depth, and subsurface integrity) about sites when warranted. Two existing sites, 38AK415 and 38AK417, situated along the C/CS-Area trunk line were revisited for this purpose.

Survey Locus 1 is located along the A-Area trunk line in a power line right-of-way northwest of the SRS cloverleaf intersection (Figure 24). This interfluvial ridge location has a low potential for substantial prehistoric deposits. Work was conducted at this locus in an attempt to relocate the previously recorded site 38AK436 discovered in 1989 during the Telecommunication Center survey. Site 38AK436 was represented by a Late Archaic stemmed hafted biface recovered during a clearcut walkover of the Telecommunication project area. No other artifacts were observed during this survey and no subsurface testing was conducted. Further information regarding 38AK436 is presented in Chapter 4.

Fieldwork for the trunk line survey at this locus consisted of subsurface testing and pedestrian coverage of exposed ground surfaces. Ten shovel tests were excavated along three transects to locate buried deposits. No artifacts were recovered from either the subsurface testing or the surface inspection, thereby substantiating the results of the 1989 survey. On the basis of these surveys, it is apparent that site 38AK436 represents an isolated artifact occurrence.

Survey Locus 2 is situated along the A-Area trunk line near the northwest floodplain margin of Upper Three Runs (Figure 25). This ridge slope location has a high potential for prehistoric archaeological resources. Work was conducted at this locus in an attempt to relocate the previously recorded site 38AK145 discovered in 1974 during the initial reconnaissance of the SRS (Hanson et al 1978:54). Site 38AK145 consisted of several chert flakes and one biface fragment exposed on the surface as a result of logging and erosion. Given its proximity to Road $\mathrm{C}$ and the bridge spanning Upper Three Runs, there is the possibility that cultural deposits at the site were disturbed during road and bridge construction.

Fieldwork for the trunk line survey in this area entailed the systematic excavation of eight shovel tests along four transects spaced at $30 \mathrm{~m}$ intervals. This investigation did not disclose the location of $38 \mathrm{AK} 145$ as all the tests were negative. Based on these results, the site is well away from the proposed trunk line route along Road C and is therefore in no danger of disturbance from trunk line construction activities. Further information concerning 38AK145 is presented in Chapter 4.

Survey Loci 3 and 4 are situated along the northwest margin of Burma Road. Locus 3 is located several hundred meters southwest of the Burma Road Borrow Pit 


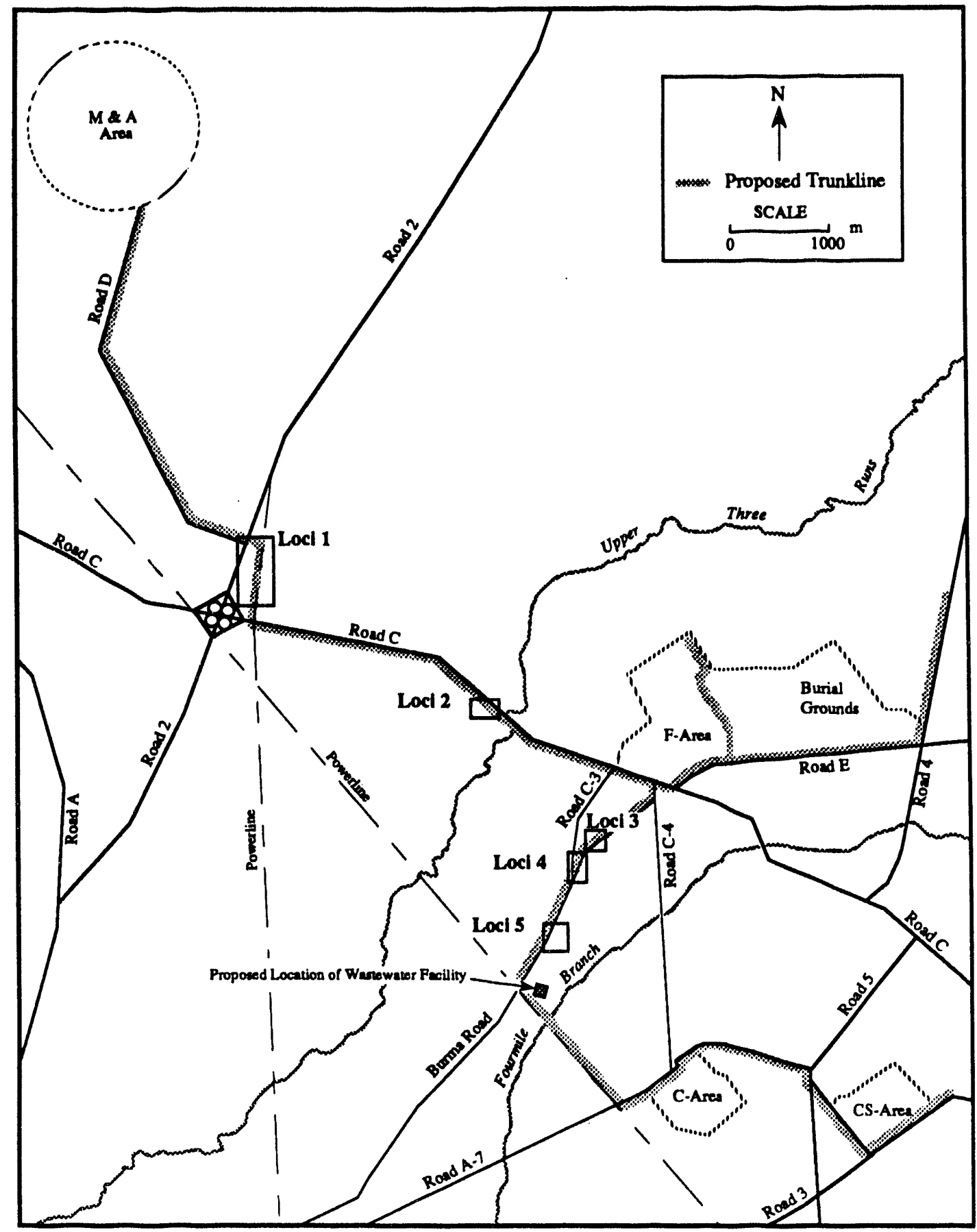

Figure 23. Location of Wastewater Facility survey loci along trunk line routes. 


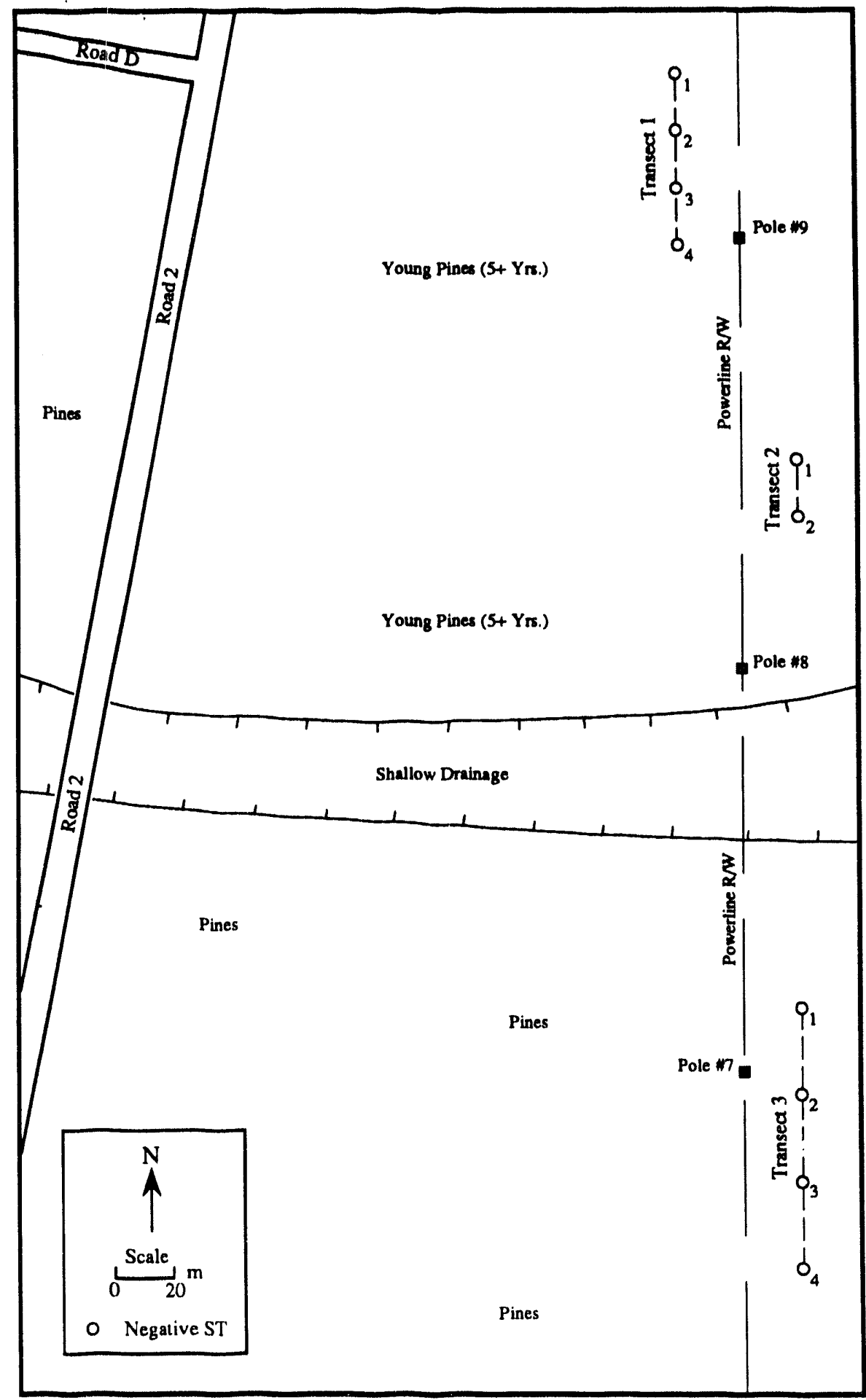

Figure 24. Map of Survey Locus 1 along the A-Area trunk line route at site $38 \mathrm{AK} 436$. 


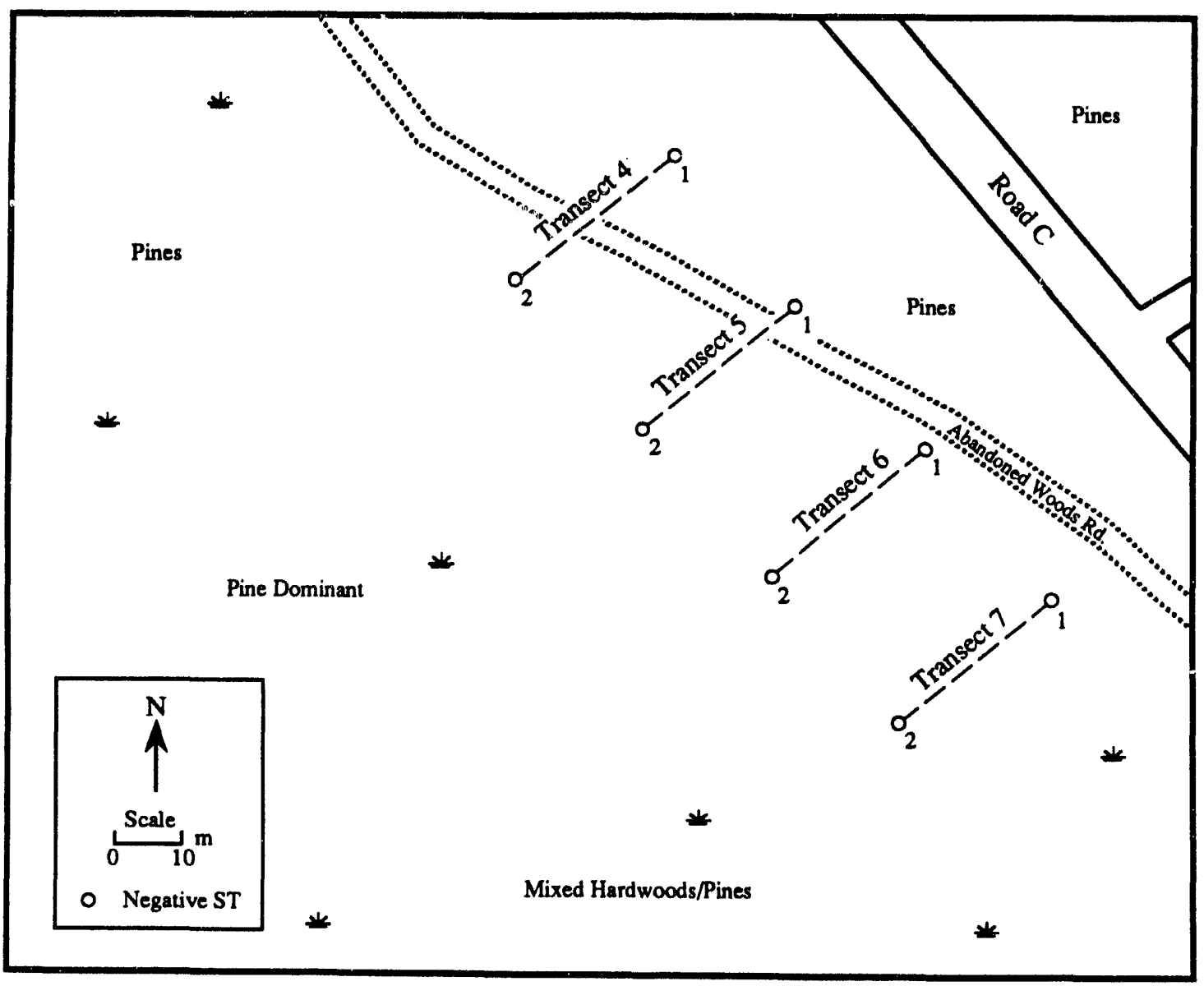

Figure 25. Map of Survey Locus 2 along the A-Area trunk line route at site 38AK145

(Figure 26) and Locus 4 is immediately southwest of Loci 3 at the intersection of Burma Road and Road C-3 (Figure 27). Testing was conducted at these loci because of the lowlevel impact from construction of Burma Road and the possibility of intact buried deposits. The areas are currently covered in planted pines and ground visibility is generally poor. However, feral pig rooting has exposed sub-plowzone soils at both loci and a borrow pit is present at Locus 4. The hog holes and borrow pit were closely inspected by the survey crew, but no artifacts were recovered. Tu detect deeply buried remains, four shovel test pits were excavated at Locus 3 and two at Locus 4. All tests were negative. The absence of artifacts at both loci along with the negative results from the Burma Road Borrow Pit survey (SRARP 1992:14) indicate a dearth of archaeological resources in the area.

Survey Locus 5 is situated along Burma Road on its southeast margin (Figure 28). Work was conducted at this loci in an attempt to relocate 38AK419. Discovered in 1984 during the Fourmile Cooling Pond survey, the site consisted of five cord-marked sherds from the same vessel exposed in a freshly plowed firebreak. Further details concerning 38AK419 are presented in Chapter 4. 


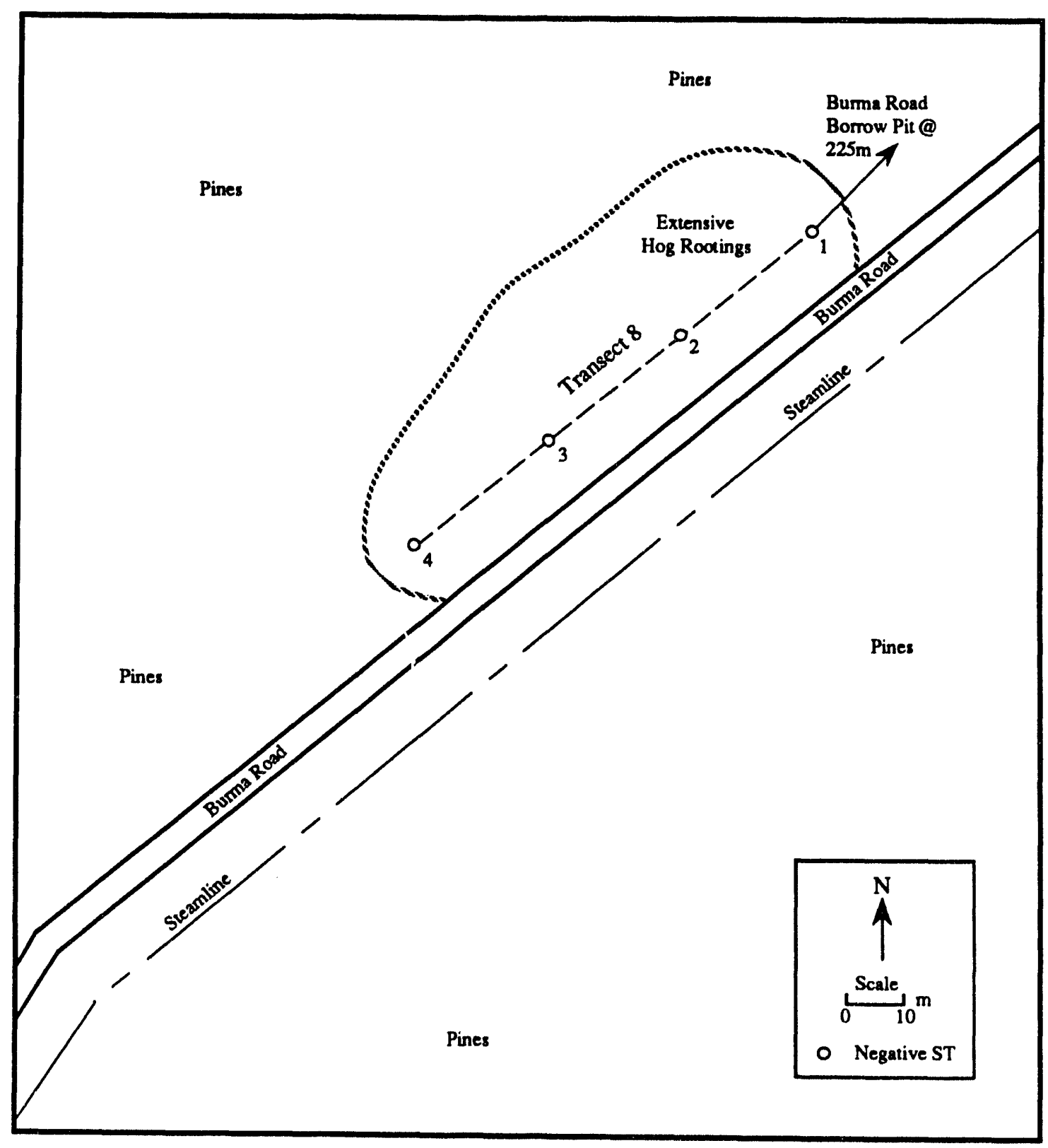

Figure 26. Map of Survey Locus 3 along the Burma Road trunk line route. 


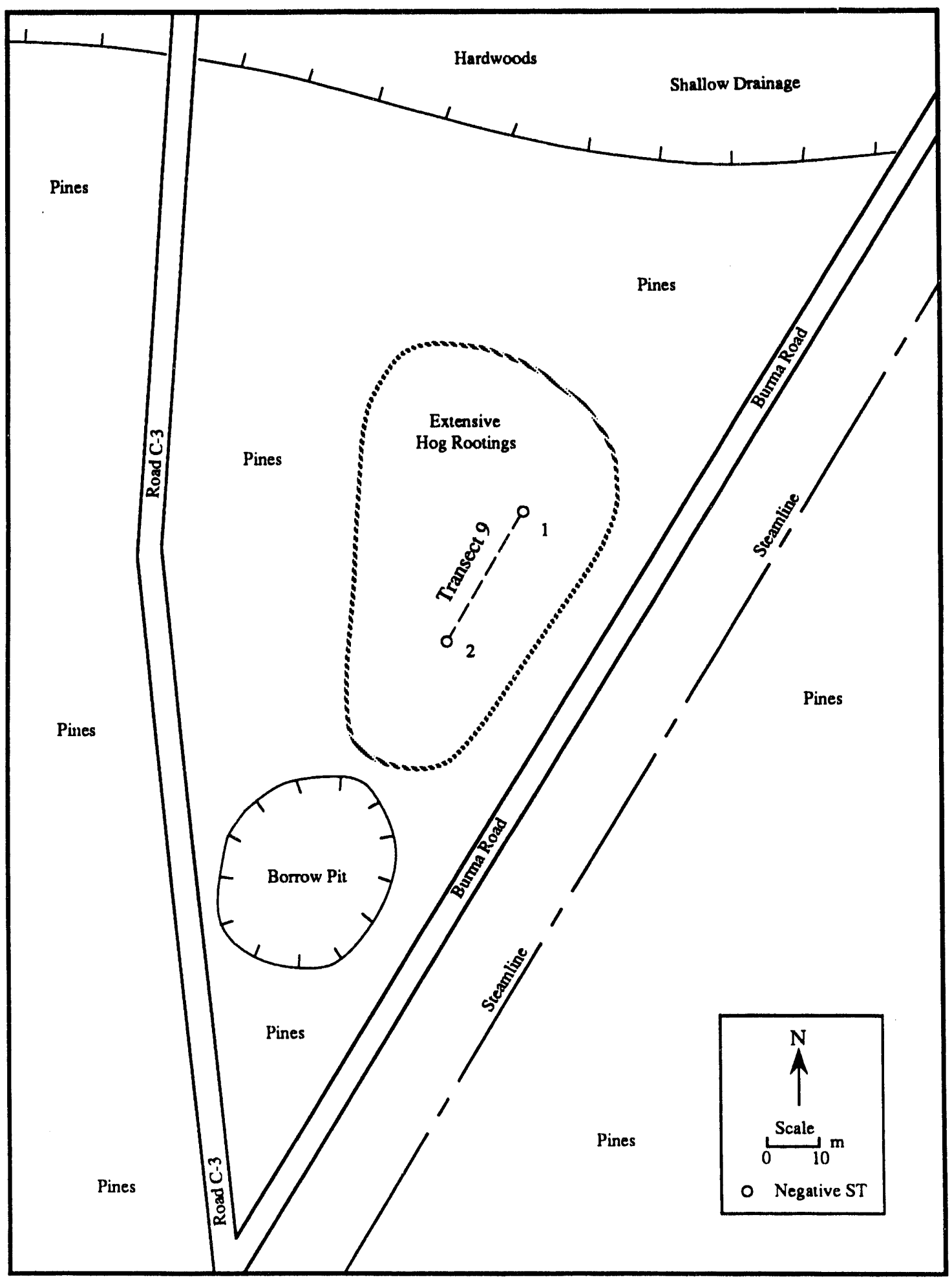

Figure 27. Map of Survey Locus 4 along the Burma Road trunk line route. 


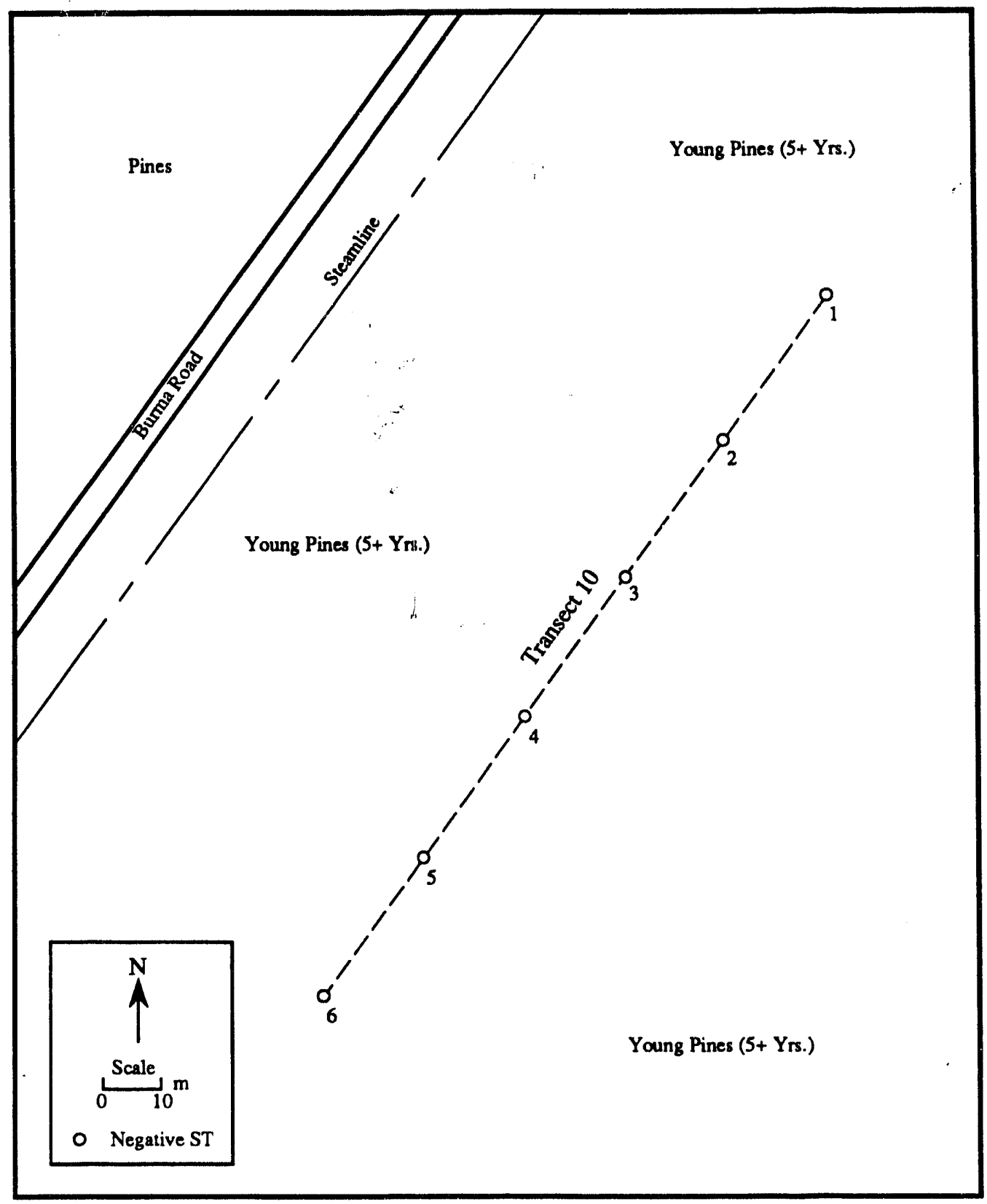

Figure 28. Map of Survey Locus 5 along the Burma Road trunk line route.

Fieldwork for the trunk line survey at this locus entailed subsurface testing and the inspection of exposed ground surface. The area is presently covered in immature planted pines and surface visibility is poor. Six shovel test pits, spaced $30 \mathrm{~m}$ apart, were excavated to detect buried deposits. No artifacts were recovered. In addition to this work, the survey team walked two recently plowed firebreaks in the area (continuations of the firebreaks bordering the six-acre footprint [Figure 22]), but no artifacts were observed. Despite these survey efforts, 38AK419 could not be relocated. In all probability, the site represents an isolated artifact occurrence as opposed to a substantial, buried component. 


\section{Summary}

Previous archaeological survey in and around the proposed Wastewater Facility project area, and especially in the vicinity of the six-acre tract, has been extensive but, until recently, not very intensive. A total of seven surveys has occurred in the project area since archaeological work began on the SRS. Given this amount of coverage, our primary survey objectives were to target previously recorded sites in the project area for further investigation and to test for new sites in the the the six-acre tract along Fourmile Branch. In addition to these efforts, surface inspection and subsurface testing was conducted at various locations along Burma Road because of the possibility for buried archaeological deposits. During survey of the Wastewater Facility trunk lines, six previously recorded sites were targeted for investigation. Despite substantial relocation efforts, only two sites were found and subjected to further testing. The six-acre tract was intensively tested for new sites because of the high potential for cultural remains. One small lithic scatter was detected and subsequently given a site designation. The Burma Road investigations did not result in the recovery of any archaeological material. The following chapter provides accounts and results of work at each of the sites. 


\section{CHAPTER 4 \\ SURVEY RESULTS}

The results of fieldwork and laboratory analysis are presented in this chapter. Investigations within the six-acre tract revealed evidence for one new site (38AK465). Two previously recorded sites (38AK415 and 38AK417) were revisited for further testing during the trunk line survey. Four other previously recorded sites (38AK92, 38AK145, 38AK419, 38AK436) in the project area could not be relocated due to the low density of artifacts at each site. This chapter includes full site characterizations for the seven sites that came under archaeological review during this project.

A South Carolina State Site Form was completed or updated according to the work performed at each site and placed on file at the SRARP laboratories at the SRS. Duplicate files are stored at the South Carolina Institute of Archaeology and Anthropology in Columbia. Methods used to identify and analyze artifacts from the SRS are fully described elsewhere (Sassaman et al. 1990:133-141) and need not be repeated here. All artifacts are curated at the SRARP. Inventories of artifacts recovered during this survey appear when warranted as tables in the following sections.

\section{SITE DESCRIPTIONS}

\section{$38 A K 92$}

Site 38AK92 was first reported after a 1974 reconnaissance survey of the SRS (Hanson et al. 1978:43-44). Located between Road $C$ and the railroad tracts (M-line), 38AK92 is situated on low ridge slope overlooking the floodplain of Tim's Branch and Upper Three Runs Creek (Table 3, Figure 19). The site was described as a half-a :re scatter of prehistoric and historic artifacts exposed in a roadcut and adjacent borrow pits. Surface collected prehistoric materials consist of three heavily patinated chert flakes and one unifacially flaked chert tool. Present in the historic assemblage are three transfer printed pearlware sherds, one alkaline glazed stoneware, and one ironstone/whiteware indicating nineteenth and early twentieth century occupations. The report contained no assessment of site condition, but the presence of borrow pits attest to severe disturbance at one time, most likely during construction of Road C through the Upper Three Runs floodplain. More recent investigations at 38AK92 during the Colonial Site survey corroborates this conclusion (Crass and Abel 1992). Of the thirteen shovel test pits excavated across the ridge top as well as along the floodplain margin of Tim's Branch, only one only one was

Table 3. Specifications for site 38AK92.

\begin{tabular}{|c|c|}
\hline $\begin{array}{l}\text { Cultural Components } \\
\text { Descriptive Site Type } \\
\text { Site Dimensions } \\
\text { Depth of Cultural Material } \\
\text { Landform Location } \\
\text { Elevation AMSL } \\
\text { Elevation Above Nearest Rank } 3 \text { Stream } \\
\text { Distance to Water } \\
\text { Soil Type } \\
\text { Soil Classification } \\
\text { Soil Description } \\
\text { Ground Cover }\end{array}$ & $\begin{array}{l}\text { Unknown prehistoric and } \\
\text { historic } \\
\text { Lithic scatter and historic } \\
\text { homesite } \\
15 \times 30 \mathrm{~m} \\
\text { Unknown } \\
\text { Ridge slope } \\
170 \mathrm{ft} \\
20 \mathrm{ft} \\
240 \mathrm{~m} \\
\text { Troup } \\
\text { Sand } \\
\text { Well drained } \\
\text { Moderate }\end{array}$ \\
\hline
\end{tabular}


positive yielding a black glass shard at $60 \mathrm{~cm}$ below surface. In a description of overall site condition, the authors concluded that local construction activities, one of which resulted in a $50 \times 100 \mathrm{~m}$ borrow pit, have apparently destroyed the archaeological context of any buried remains. In light of this recent work, it was apparent that 38AK92 had little archaeological potential and therefore warranted no further consideration during trunk line survey for the Wastewater Facility.

\section{$38 A K 145$}

Site 38AK145 was originally discovered during the 1973-1977 transect reconnaissance of the SRS (Hanson et al. 1978: 54). This prehistoric site is located along the slope of a ridge line near the confluence of Tim's Branch and Upper Three Runs Creek (Table 4, Figure 19). At the time of initial survey, the site was in a clearcut and portions were badly eroded. A surface inspection revealed the presence of three chert flakes and one hafted biface fragment scattered in exposed sand and clay. No subsurface testing was conducted. Although no identifiable diagnostics were recovered, an Archaic period occupation was inferred on the basis of general artifact characteristics.

At present, the site is covered in mature planted pines. The soil survey map for the area classifies the soil type as Orangeburg, a well drained sand that is usually found on high ridges (Rogers 1990: 26, soil map 15). However, in this case the soil type is restricted to a small area in the surrounding fluvaquent soils of the Upper Three Runs Creek floodplain, thus possibly indicating the presence of a relict sand body.

Site 38AK145 could not be relocated despite a substantial effort at subsurface testing in the alleged location of the site. Fieldwork entailed the systematic excavation of eight shovel tests along four transects spaced at about $30 \mathrm{~m}$ intervals (Figure 25). All tests were negative. Based on the results of survey in 1977, 38AK145 appears to be a low density scatter of lithic debris. If this is the case, then detection of buried deposits with shovel test pits may be difficult. It is also possible that site integrity is poor due to past land use activities. The 1978 description reports considerable surface erosion resulting from logging at the site. Also, given the site's proximity to Road C and the bridge spanning Upper Three Runs, it is likely that sand was removed for road fill during highway and bridge construction through the floodplain.

Table 4. Specifications for site 38AK145.

\begin{tabular}{ll}
\hline Cultural Components & Possible Archaic \\
Descriptive Site Type & Lithic scatter \\
Site Dimensions & $30 \times 30 \mathrm{~m}$ \\
Depth of Cultural Material & Unknown \\
Landform Location & Ridge slope \\
Elevation AMSL & $130 \mathrm{ft}$ \\
Elevation Above Nearest Rank 3 Stream & $10 \mathrm{ft}$ \\
Distance to Water & $150 \mathrm{~m}$ \\
Soil Type & Orangeburg \\
Soil Classification & Loamy sand \\
Soil Description & Well drained soil \\
Ground Cover & Heavy \\
\hline
\end{tabular}




\section{$38 A K 415$}

Initially discovered and tested during the 1984 Cooling Pond survey of Fourmile Branch (Martin et al 1985; Sassaman et al. 1990:80-81), 38AK415 was targeted for additional testing by SRARP personnel during the trunk line survey. As a result of this recent work, buried deposits were found to be more extensive and intact than originally suspected.

The previously published site description characterizes 38AK415 as a Middle Woodland period occupation (Martin et al. 1985:126-127). The site is situated on a ridge nose along the southeastern margin of the Fourmile Branch floodplain, and is bordered on the north by an unnamed Rank-1 drainage (Table 5, Figures 19 and 29). Elevated at about $200 \mathrm{ft}(61 \mathrm{~m})$ above mean sea level, the sites rises about $30 \mathrm{ft}$ (nine meters) in elevation above Fourmile Branch. The site locale has a two percent slope grading to the northwest. The soil type, as reported in the original site description, is of the Vaucluse-Blaney variety (Aydellott n.d.:6). A recent soil report for the SRS, however, classifies the soil type as Troup, which consists of well drained yellowish brown sand over light reddish brown sand together reaching a depth of around 54 inches below surface with yellowish red sandy clay loam underlying this to about 81 inches (Rogers 1990:32-33, soil map 21).

Current land use at the site is slash pine (Pinus elliottii) silvaculture. The present crop of trees has less than five years of growth. Prior to seedling planting, heavy machinery was used to rake clearcut timber debris into windrows that were still evident at the time of investigation. This land preparation technique generally has no more impact on shallow archaeological resources at sandy Coastal Plain sites than agricultural activities. Additional land use consist of a power line right-of-way, approximately $30 \mathrm{~m}$ wide, that bisects the site from northwest to southeast. Low vegetation, controlled through the use of herbicides, covers the right-of-way ground surface. Pairs of transmission line poles are present along the center of the power line cut and a dirt road parallels the right-of-way just inside the northeast margin. The power line was constructed sometime prior to 1950 as it is visible in a mid-twentieth century aerial photograph of the area (United States Atomic Energy Commission Aerial Photographs 1951: SRP 1-65). The same photograph shows the adjacent land as fallow, possibly in use as pasture. It is quite likely that 38AK415 was subjected to agricultural plowing at various times during the historic period.

Site 38AK415 was initially located through subsurface testing of the ridge nose in 1984. At this time, ten shovel tests were excavated along Proveniences $1-3$ and one single shovel test located $15 \mathrm{~m}$ west of the original datum to about $60 \mathrm{~cm}$ below surface. Four of the test were positive producing eight pieces of debitage, one bold check stamped sherd, and three eroded sand-tempered sherds. The low number of positive tests indicated that the site was confined to a area east of the power line right-of-way with estimated dimensions of $20 \mathrm{~m}$ north/south by $10 \mathrm{~m}$ east/west. Site function was interpreted as a limited-activity area on the basis of low artifact density and lack of assemblage diversity.

Although the site was judged ineligible for the National Register of Historic Places and no further testing was recommended (Martin et al. 1985:127), SRARP staff felt that the site did warrant additional investigation during the Wastewater Facility trunk line survey given its location on a prominent landform at the confluence of Fourmile Branch and an unnamed tributary. Accordingly, the site was revisited over a five day period during July of 1992. Fieldwork was initiated with the systematic excavation of 39 shovel tests pits (STPs) along Proveniences 4-16 and one transect of four negative STPs. This effort resulted in the recovery of 151 artifacts, including five sherds, 145 flakes, and one biface 
Table 5. Specifications for site 38AK415.

\begin{tabular}{ll}
\hline Cultural Components & Middle Woodland \\
Descriptive Site Type & Prehistoric Habitation \\
Site Dimensions & $60 x 125 \mathrm{~m}$ \\
Depth of Cultural Material & $70 \mathrm{~cm} \mathrm{BS}$ \\
Landform Location & Ridge nose \\
Elevation AMSL & $200 \mathrm{ft}$ \\
Elevation Above Nearest Rank 3 Stream & $30 \mathrm{ft}$ \\
Distance to Water & $150 \mathrm{~m}$ \\
Soil Type & Sand \\
Soil Classification & Troup \\
Soil Description & Well drained \\
Ground Cover & Moderate \\
\hline
\end{tabular}

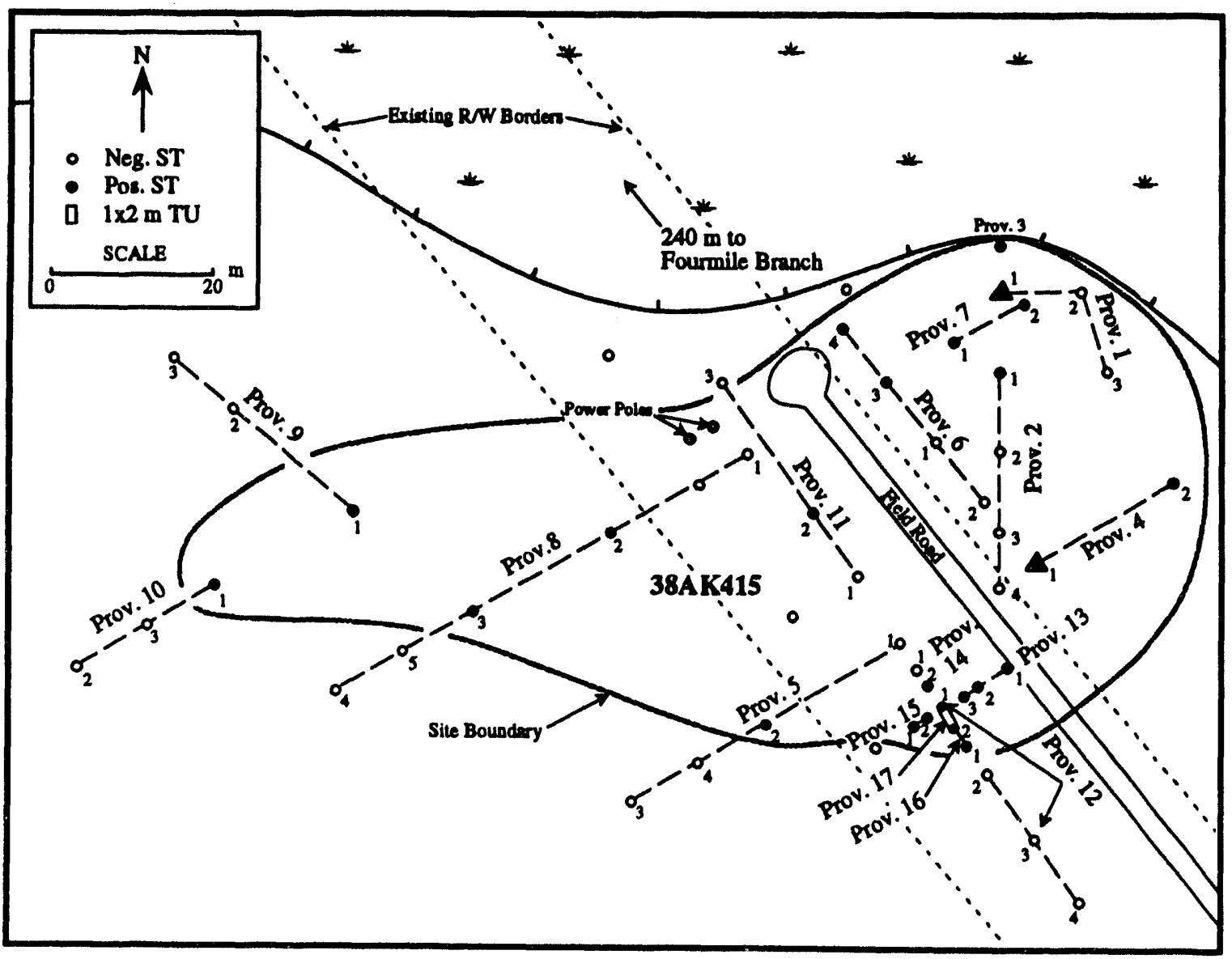

Figure 29. Map of site 38AK415 showing shovel test transects and test unit locations. 
tip from 21 positive tests (Table 6). As these data demonstrate, archaeological deposits extend over a much larger area than originally defined in 1984. Site size was therefore expanded across the ridge nose to include the power line right-of-way and adjacent areas to the east and west. Based on positive shovel tests and surface scatters of artifacts, new site dimensions were estimated at $60 \mathrm{~m}$ north/south by $125 \mathrm{~m}$ east/west encompassing an area of 0.75 ha. Moreover, close interval shovel tests in the right-of-way along the southern boundary of the site revealed a dense concentration of lithic debris.

To assess the subsurface integrity at $38 \mathrm{AK} 415$, a $1 \times 2 \mathrm{~m}$ test unit, designated Provenience 17, was dug in the right-of-way where the lithic concentration was discovered. Specifically, the test unit was laid out between STP 1 of Provenience 12 and STP 2 of Provenience 16 as these two shovel tests had produced more artifacts than any other test excavated. Provenience 17 was oriented 135 degrees east of north and, in the absence of natural stratigraphy, excavated in arbitrary $10 \mathrm{~cm}$ levels to a depth of $70 \mathrm{~cm}$ BS. The exposed soil profile contained two distinct zones (Figure 30). From the surface to a depth of about $15 \mathrm{~cm}$ BS was a very dark grayish brown (10YR3/2) sandy loam topsoil. In general, contact between the topsoil and underlying zone was sharp, although some organic leaching was evident. From the base of the topsoil to $70 \mathrm{~cm} \mathrm{BS}$ is a homogeneous brownish yellow (10YR6/6) fine sand. At about $34 \mathrm{~cm}$ BS in the northeastern corner of the test unit, a "pocket" of gray brown sand encasing the remains of a burnt tree root was encountered. Beginning several centimeters above the burnt root and extending about 60 $\mathrm{cm}$ along the east profile was an area of orange tan sand. Although the origin of this orange tan soil stain is somewhat difficult to determine, it is most likely the result of natural rather than cultural processes. The stain may represent subsurface disturbance from animal borrowing though it is quite possible that the orange colored sand is a product of heat oxidation associated with the tree burn.

Table 6. Artifact Inventory by Shovel Test Provenience, 38AK415.

\begin{tabular}{|c|c|c|c|c|c|c|}
\hline $\begin{array}{l}\text { Shovel Test } \\
\text { Prov. }\end{array}$ & $\begin{array}{l}\text { Other } \\
\mathrm{Ct} \text {. }\end{array}$ & $\begin{array}{l}\text { Bifaces } \\
\text { Wt.(g) }\end{array}$ & $\begin{array}{l}\text { De } \\
\text { Ct. }\end{array}$ & $\begin{array}{l}\text { it a ge } \\
\text { Wt.(g) }\end{array}$ & Sherds & TOTALS \\
\hline $\begin{array}{l}4 x(1) \\
4 \times(2) \\
5 x(2) \\
6 x(3) \\
6 x(4) \\
7 \times(1) \\
7 \times(2)\end{array}$ & 1 & 11.1 & $\begin{array}{l}2 \\
1 \\
2 \\
1 \\
1 \\
5\end{array}$ & $\begin{array}{l}1.7 \\
0.1 \\
0.3 \\
0.2 \\
0.5 \\
4.6\end{array}$ & $2^{8}$ & $\begin{array}{l}2 \\
2 \\
1 \\
2 \\
1 \\
1 \\
5\end{array}$ \\
\hline $8 \times(2)$ & $1^{b}$ & 2.1 & 7 & 7.9 & & 8 \\
\hline $\begin{array}{l}8 \times(3) \\
9 \times(1) \\
10 \times(1) \\
11 \times(2) \\
12 \times(1) \\
13 \times(1) \\
13 \times(2) \\
13 \times(3) \\
14 \times(2)\end{array}$ & & & $\begin{array}{r}3 \\
4 \\
1 \\
25 \\
1 \\
9 \\
6 \\
1\end{array}$ & $\begin{array}{r}2.7 \\
0.5 \\
1.8 \\
19.9 \\
1.4 \\
2.4 \\
2.5 \\
0.2\end{array}$ & $1^{c}$ & $\begin{array}{r}1 \\
3 \\
4 \\
1 \\
25 \\
1 \\
9 \\
6 \\
1\end{array}$ \\
\hline $\begin{array}{l}15 \times(1) \\
15 \times(2) \\
16 \times(1) \\
16 \times(2) \\
\end{array}$ & & & $\begin{array}{r}4 \\
2 \\
7 \\
63 \\
\end{array}$ & $\begin{array}{r}2.9 \\
1.3 \\
3.4 \\
39.2 \\
\end{array}$ & $2^{d}$ & $\begin{array}{r}6 \\
2 \\
7 \\
63\end{array}$ \\
\hline Total & 1 & 2.1 & 145 & 297.8 & 5 & 151 \\
\hline
\end{tabular}



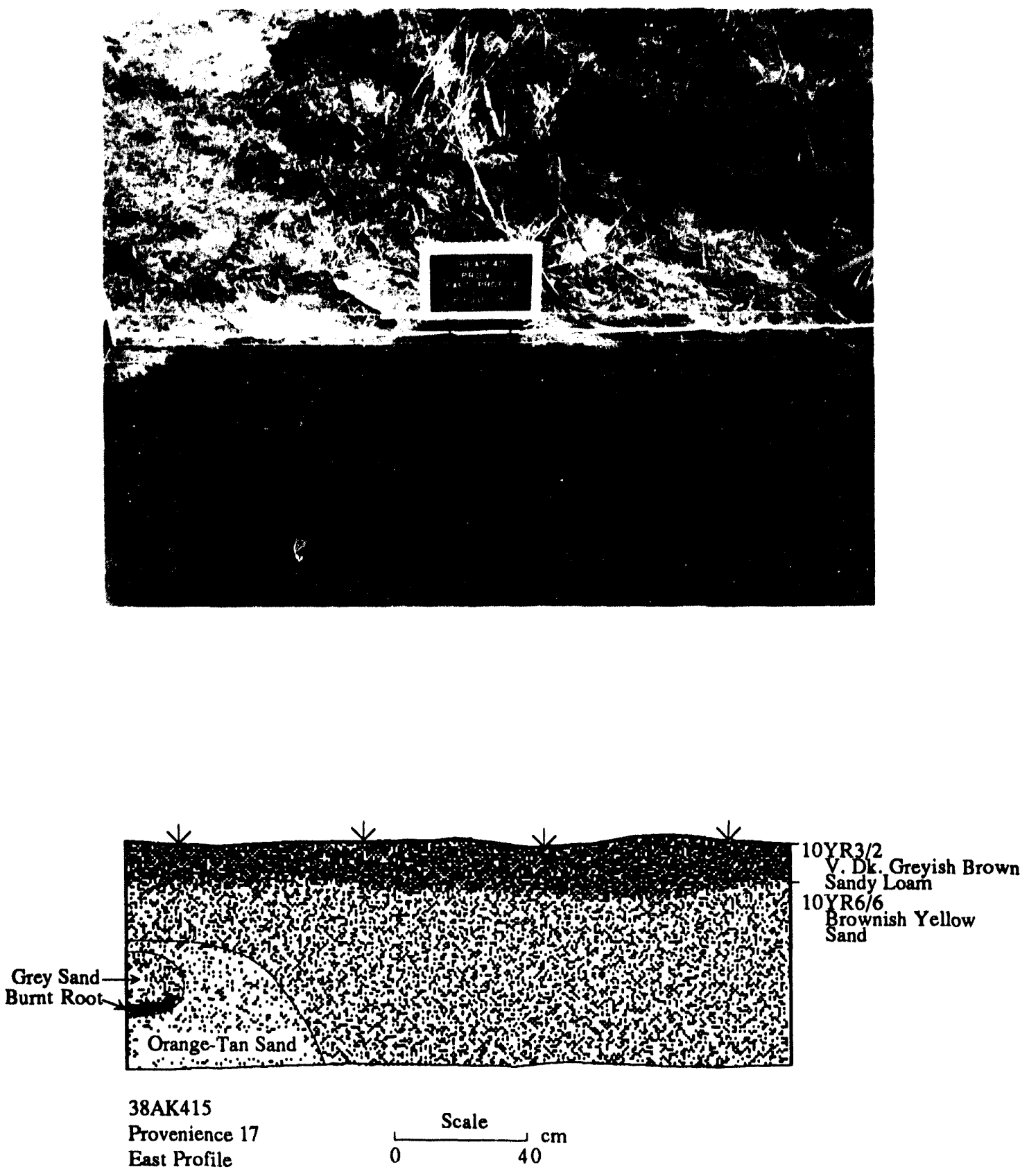

Figure 30. Drawing and photograph of east profile, Provenience 17, 38AK415. 
The presence of this flaked stone reduction feature serves as possible indirect evidence for an associated habitation structure. Based on the spatial patterning of artifact concentrations at 38AK157 along Upper Three Runs, Sassaman (1992a: 268-269, Figure 111) developed a model of Early Woodland household structure for the Aiken Plateau that includes an exterior flaked stone reduction area. Although, the lithic feature at 38AK415 seems to be Middle Woodland in origin, it is quite possible that habitation structures and activity areas of this period remained similar to those proposed for Early Woodland households. Of course, more extensive excavations in the vicinity of the lithic concentration at 38AK 415 would, in all likelihood, bring more evidence to bear on the presence and structure of Middle Woodland household organization.

The vertical location of this intact lithic concentration suggests that the prehistoric occupation surface lies somewhere between 10 and $30 \mathrm{~cm}$ BS. The basis for this inference is directly related to the depositional process responsible for sub-plowzone remains. Some archaeologists working at sites in the Coastal Plain have tended to regard bioturbation as the major agency creating archaeological stratigraphy (Michie 1990). However, the fact that cultural features, such as the lithic concentration at $38 \mathrm{AK} 415$, are often found intact brings into question the uniformity of bioturbational disturbances. Recent geoarchaeological work on the SRS has demonstrated that subsurface archaeological deposits were buried by geological processes (Brooks 1992; Brooks and Sassaman 1990; Sassaman 1992b). In particular, grain size data from shallow/conflated deposits along the bluff margins of tributaries in the Aiken Plateau strongly suggests that episodic colluvial events, rather than bioturbation, is the principle means by which sites are buried on nonalluvial low sloping landforms (Sassaman 1992b). Although grain size data are not available for 38AK415, it is hypothesized that the Middle Woodland occupational surface as well as the shallow, intact lithic concentration were buried and preserved as a result of colluviation. The presence of eleven flakes from 40 to $70 \mathrm{~cm}$ BS in Provenience 17 is most likely the result of vertical displacement from the lithic feature. This small occurrence of flakes is attributed to factors of bioturbation and further demonstrates that this postdepositional process has had minimal effect on buried deposits at the site. Similarly, the well preserved condition of the lithic concentration attest to the low impact that historic activities such as plowing, logging, and right-of-way clearing have had on the subplowzone archaeological surface. The information obtained from Provenience 17 indicates that the subsurface integrity at 38AK415 is good.

\section{$38 A K 417$}

Initially discovered during the 1984 Cooling Pond survey of Fourmile Branch (Martin et al. 1985; Sassaman et al. 1990:80-81), 38AK417 was targeted for additional testing during the trunk line survey. The previously published description characterizes 38AK417 as a multicomponent lithic and ceramic scatter with site use spanning the entire Woodland period (Martin et al. 1985:127, Figure 49). However, the results of testing during the Wastewater project indicate that site occupation occurred during the Middle Archaic, Middle Woodland, and Late Woodland periods. Additionally, this recent work demonstrated that buried archaeological deposits were far less extensive than originally reported.

Site 38AK417 is situated on a ridge nose along the northwest margin of the Fourmile Branch floodplain (Table 9, Figures 19 and 31). The landform is at an elevation of $180-190 \mathrm{ft}(55-58 \mathrm{~m})$ above mean sea level, rising six meters $(20 \mathrm{ft})$ above Fourmile Branch. The site locale has a two percent slope grading to the northeast. As reported in the original site description, the soil is typed as Troup (Aydellott n.d.:20). A recent soil survey 
Table 9. Specifications for site 38AK417.

\begin{tabular}{ll}
\hline Cultural Components & $\begin{array}{l}\text { Middle Archaic, Middle } \\
\text { ond Late Woodland }\end{array}$ \\
Descriptive Site Type & $\begin{array}{l}\text { Prehistoric habitation } \\
65 \times 200 \mathrm{~m}\end{array}$ \\
Site Dimenaions & $50 \mathrm{~cm} \mathrm{BS}$ \\
Depth of Cultural Material & Ridge nose \\
Lendform Location & $180.190 \mathrm{At}$ \\
Elevation AMSL & $10-20 \mathrm{At}$ \\
Elevation Above Neareat Rank 3 Strosm & $125 \mathrm{~m}$ \\
Distance to Water & Sand \\
Soil Type & Lucy \\
Soil Classification & Well drained \\
Soil Description & Heavy \\
Ground Cover &
\end{tabular}

for the SRS, however, has reclassified the soil type as Lucy, consisting of well drained brown sand extending about seven inches below surface and overlying yellowish red loamy sand from seven to 25 inches. The subsoil from 25 to 30 inches is red sandy loam with an underlying layer of red sandy clay loam from 30 to 62 inches (Rogers 1990:22-23, soil map 21).

Current land use at the site consists of a longleaf pine (Pinus palustris) plantation with pole-sized trees. Additional land use includes a power line right-of-way, approximately $30 \mathrm{~m}$ wide, oriented northwest to southeast along the northeastern portion of the site. Low vegetation, controlled through the use of herbicides, covers the right-of-way ground surface. Pairs of transmission line poles in addition to a dirt access road are present along the center of the power line cut. The southwest margin of the right-of-way, just inside the treeline, is bordered by low bulldozed spoil piles that are most likely the product of grading for the right-of-way. The power line was constructed sometime prior to 1950 as it is visible on a mid-twentieth century aerial photograph (United States Atomic Energy Commission Aerial Photographs 1951: SRP 1-65). The same photograph shows the site covered in mature trees with agricultural fields just to the north. The possibility remains that 38AK417 was subjected to agricultural plowing during the early historic period. However, the presence of mature trees in 1951 may indicate that the area was too low for adequate crop yields.

Site 38AK417 was initially located through subsurface testing of the ridge nose in 1984 (Martin et al. 1985:127). At this time, 35 shovel tests were excavated along Proveniences $1-4,6,8$, and 9 and two negative transects to approximately $60 \mathrm{~cm} \mathrm{BS}$. Also, two surface collections were made: one from a freshly plowed firebreak that crossed the site (Provenience 5) and a second general collection from across the site (Provenience 7). On the basis of positive shovel tests, the site dimensions were established as $60 \mathrm{~m}$ northwest/southeast by $275 \mathrm{~m}$ northeast/southwest (Martin et al. 1985: Figure 49). The combined artifact assemblage from the surface collections and nine positive shovel tests yielded a total of 108 items inventoried in Tables 10 and 11. Time sensitive artifacts in this assemblage are represented by one small triangular point as well as a total of 21 Deptford Simple Stamped, Deptford Linear Check Stamped, Deptford Linear Check Stamped/Simple Stamped, yar. Katherine, Deptford Bold Check Stamped, and bold and fine cordmarked sherds all indicating site habitation during the Middle and Late Woodland periods (Sassaman and Anderson 1990:164-168, 192-202). 


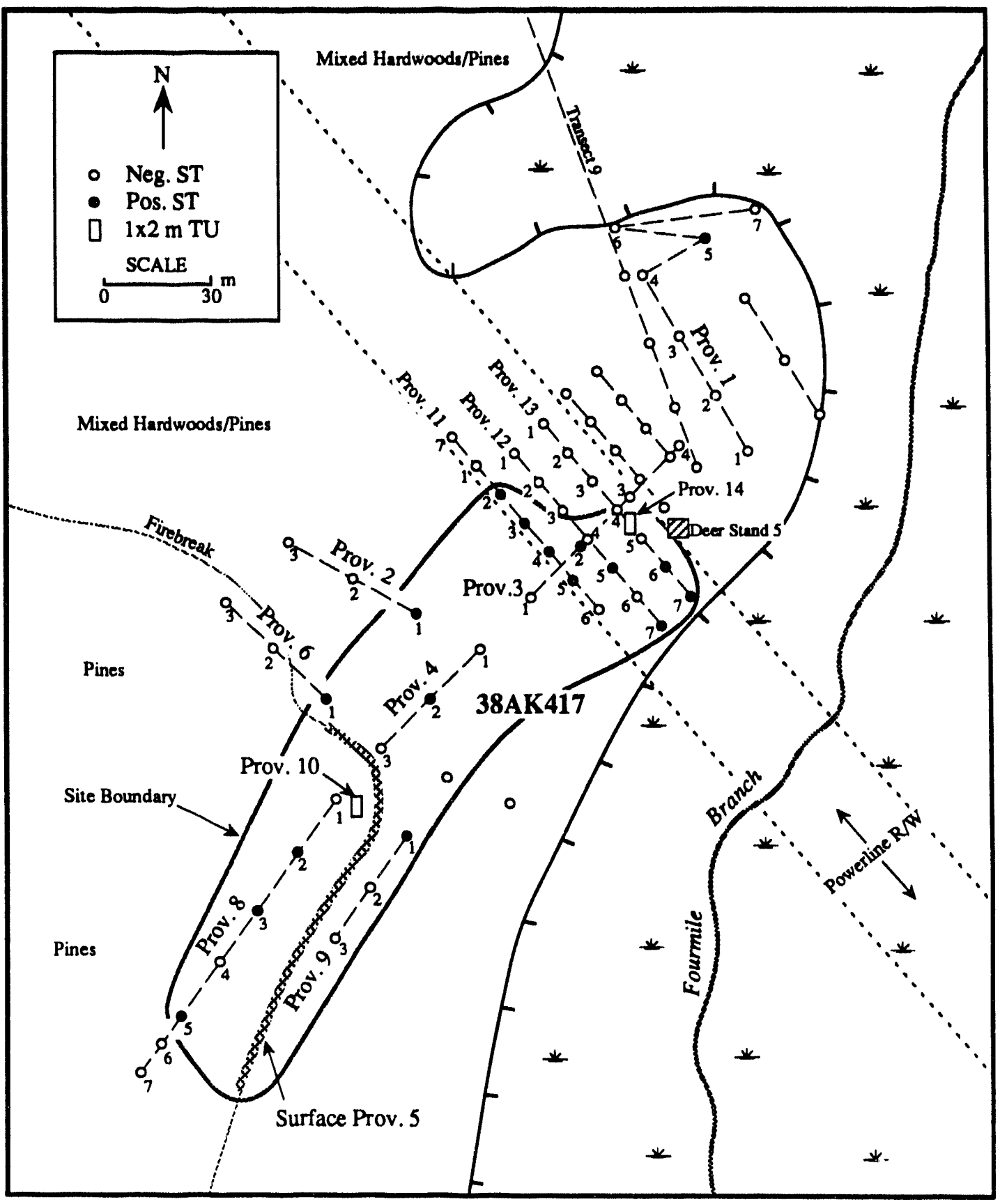

Figure 31. Map of site 38AK417 showing shovel test transects and test unit locations. 
Table 10. Ceramic Artifact Inventory by Provenience from 1984 Survey, 38AK417.

\begin{tabular}{|c|c|c|c|c|c|c|c|c|}
\hline Prov. & $\begin{array}{l}\text { Sand Temp. } \\
\text { Plain }\end{array}$ & $\begin{array}{c}\text { Deptford } \\
\text { Linear } \\
\text { Check Stamped }\end{array}$ & $\begin{array}{c}\text { Deptford } \\
\text { LCS/SS } \\
\text { (var. Katherine) }\end{array}$ & $\begin{array}{l}\text { Deptiond } \\
\text { Simple } \\
\text { Stamped }\end{array}$ & $\begin{array}{l}\text { Deptford } \\
\text { Check } \\
\text { Stamped }\end{array}$ & $\begin{array}{c}\text { Cord } \\
\text { Marked }\end{array}$ & Eroded & TOTALS \\
\hline $\begin{array}{l}2 \times(1) \\
50 \\
70 \\
9 \times(1)\end{array}$ & $\begin{array}{l}4 \\
1 \\
\end{array}$ & $\begin{array}{l}1 \\
1 \\
7\end{array}$ & 1 & 1 & $\begin{array}{l}2 \\
2\end{array}$ & 7 & $\begin{array}{r}2 \\
13\end{array}$ & $\begin{array}{r}1 \\
6 \\
34 \\
1 \\
\end{array}$ \\
\hline Total & 5 & 9 & 1 & 1 & 4 & 7 & 15 & 42 \\
\hline
\end{tabular}

Table 11. Lithic Artifact Inventory by Provenience from 1984 Survey, 38AK417.

\begin{tabular}{|c|c|c|c|c|c|}
\hline Prov. & Debitage & $\begin{array}{c}\text { Hafted } \\
\text { Bifaces }\end{array}$ & $\begin{array}{l}\text { Orthoquartzite } \\
\text { Nodule }\end{array}$ & $\begin{array}{c}\text { Fire-Cracked } \\
\text { Rock }\end{array}$ & TOTALS \\
\hline $\begin{array}{l}1 \times(5) \\
3 x(2) \\
4 x(2)\end{array}$ & $\begin{array}{l}1 \\
6 \\
1\end{array}$ & & & & $\begin{array}{l}1 \\
6 \\
1\end{array}$ \\
\hline $\begin{array}{l}50 \\
6 \times(1)\end{array}$ & $\begin{array}{r}16 \\
4\end{array}$ & $2^{a}$ & & & $\begin{array}{r}18 \\
4\end{array}$ \\
\hline $\begin{array}{l}70 \\
8 \times(2) \\
8 \times(3) \\
8 \times(5)\end{array}$ & $\begin{array}{c}22 \\
5 \\
1 \\
2\end{array}$ & & 1 & 5 & $\begin{array}{c}28 \\
5 \\
1 \\
2\end{array}$ \\
\hline Total & 58 & 2 & 1 & 5 & 66 \\
\hline
\end{tabular}

Although 38AK417 was considered eligible for the National Register of Historic Places, the original investigators recommended more intensive work at the site to properly evaluate its significance (Martin et al. 1985:127). In July of 1992 and again in June and July of 1993, SRARP personnel revisited 38AK415 and conducted further testing over a total of six days. This fieldwork entailed the systematic excavation of $\mathbf{3 0}$ shovel test pits (STPs) and two $1 \times 2 \mathrm{~m}$ test units. In addition, four negative shovel tests already had been dug along an engineer's transit line, labelled Transect 9, which crossed 38AK415 along its northeastern edge, during survey of the six-acre tract. This effort resulted in the recovery of 26 artifacts, including 10 sherds, 15 flakes, and one Eared Yadkin hafted biface (Coe 1964:47) from eight positive shovel tests (Table 12). Diagnostic pottery types included four Deptford Linear Check Stamped/Simple Stamped, yar. Katherine sherds, representing one vessel, and two Middle to Late Woodland period cord-marked sherds (Sassaman and Anderson 1990:192-202). In addition, the single Eared Yadkin triangular in the collection was a type not found during the 1984 testing and is associated with the Deptford component (Anderson 1987; Sassaman and Anderson 1990:162-164).

During the course of this work, it became obvious that there was a substantial decrease in positive STPs along the northeast portion of the site as defined in 1984. Altogether, 24 STPs were excavated northeast of the power line right-of-way during the 1984 and 1992-93 projects with only a single flake recovered (STP 5 of Provenience 1). As a result, the northeastern site boundary was altered to include only positive tests. The new site dimensions were estimated at $60 \mathrm{~m}$ northwest/southeast by $200 \mathrm{~m}$ northeast/southwest encompassing an area of $1.2 \mathrm{ha}$. 
Table 12. Artifact Inventory by Shovel Test Provenience, 38AK417.

\begin{tabular}{|c|c|c|c|c|c|}
\hline $\begin{array}{l}\text { Shovel Test } \\
\text { Prov. }\end{array}$ & Hafted Bifaces & $\begin{array}{l}\text { De } \\
\text { Ct. }\end{array}$ & $\begin{array}{l}\text { it } 28 \mathrm{~g} \\
\mathrm{Wt} .(\mathrm{g})\end{array}$ & Sherds & TOTALS \\
\hline $11 \times(2)$ & & 1 & 0.1 & & 1 \\
\hline $\begin{array}{l}11 \times(3) \\
11 \times(4) \\
11 \times(5) \\
12 \times(5)\end{array}$ & $1^{a}$ & $\begin{array}{r}1 \\
1 \\
10\end{array}$ & $\begin{array}{r}0.9 \\
3.8 \\
15.9\end{array}$ & & $\begin{array}{r}1 \\
1 \\
1 \\
10\end{array}$ \\
\hline $12 \times(7)$ & & & & $1^{b}$ & 1 \\
\hline $13 x(6)$ & & & & $1^{b}$ & 1 \\
\hline $13 \times(7)$ & & 2 & 1.7 & $8^{c}$ & 10 \\
\hline Total & 1 & 15 & 22.4 & 10 & 26 \\
\hline
\end{tabular}

a Eared-Yadkin; ${ }^{b}$ cord-marked sherd; ${ }^{c} 4$ Deptford Linear Check Stamped, yar. Katherine sherds and 4 crumb sherds

To effectively assess the subsurface integrity of 38AK417, two $1 \times 2 \mathrm{~m}$ test units, designated Proveniences 10 and 14, were excavated in different areas of the site. Provenience 10 was placed in proximity to an old firebreak where a high occurrence of artifacts was noted in 1984. This test unit was oriented to cardinal directions and excavated in arbitrary $10 \mathrm{~cm}$ levels, with the exception of Level A which consisted of a $20 \mathrm{~cm}$ topsoil layer, to a depth of $70 \mathrm{~cm}$ BS. The exposed soil profile contained two strata (Figure 32). From the surface to a depth of al jut $20 \mathrm{~cm}$ BS was a dark brown (10YR3/3) sandy loam topsoil. Contact with the underlying zone was sharp. This underlying zone consisted of a homogeneous light yellowish brown (10YR6/4), very compacted, fine sand extending to $70 \mathrm{~cm}$ BS.

Provenience 14 was located in the power line right-of-way along the northeastern boundary of the site as redefined during this project. Specifically, the test unit was laid out between STPs 4 and 5 of Provenience 13, to investigate subsurface deposits on a portion of the site where shovel testing revealed low artifact density. The test unit was oriented in cardinal directions and excavated in arbitrary $10 \mathrm{~cm}$ levels to a depth of $70 \mathrm{~cm}$ BS. The exposed soil profile contained two recognizable strata (Figure 33). From the surface to a depth of about 20-24 cm BS is a brown (10YR5/3) sandy loam topsoil. Contact with the underlying zone is sharp. Below the topsoil to the base of the excavation is a yellowish brown (10YR3/6) silty very-fine sand. This otherwise uniform subsoil matrix is disrupted in the southeast corner by a subunit of mottled dark greyish brown (10YR4/2) and yellowish brown (10YR3/6) sandy loam. In all probability, this subsoil disturbance, which originated at the base of the topsoil and extended into the floor of the test unit, was the result of a decayed tree tap root.

The prehistoric cultural material recovered from Provenience 10, Levels A-D (0-50 $\mathrm{cm}$ BS) totalled 21 artifacts. As is evident from the inventory in Table 13, there are no diagnostics in the collection. Lithic debitage $(\mathrm{N}=17)$ was present in all levels producing artifacts though a decrease in quantity was noted in Levels $C$ and D. Pottery was contained in the upper $30 \mathrm{~cm}$ and is represented by one sand-tempered plain, one sand-tempered eroded, and one crumb sherd. The final item in the assemblage is a small bone fragment from Level B (20-30 cm BS) that was either intrusive or the product of differential preservation of prehistoric organic materials in the acidic Coastal Plain sands.

The inventory of artifacts from Provenience 14 is presented in Table 14. A total of 21 items was recovered from Levels A $(0-10 \mathrm{~cm} \mathrm{BS})$ and C-E $(20-50 \mathrm{~cm} \mathrm{BS})$. The only time sensitive artifact is a Morrow Mountain hafted biface in Level D (30-40 cm BS) that is 

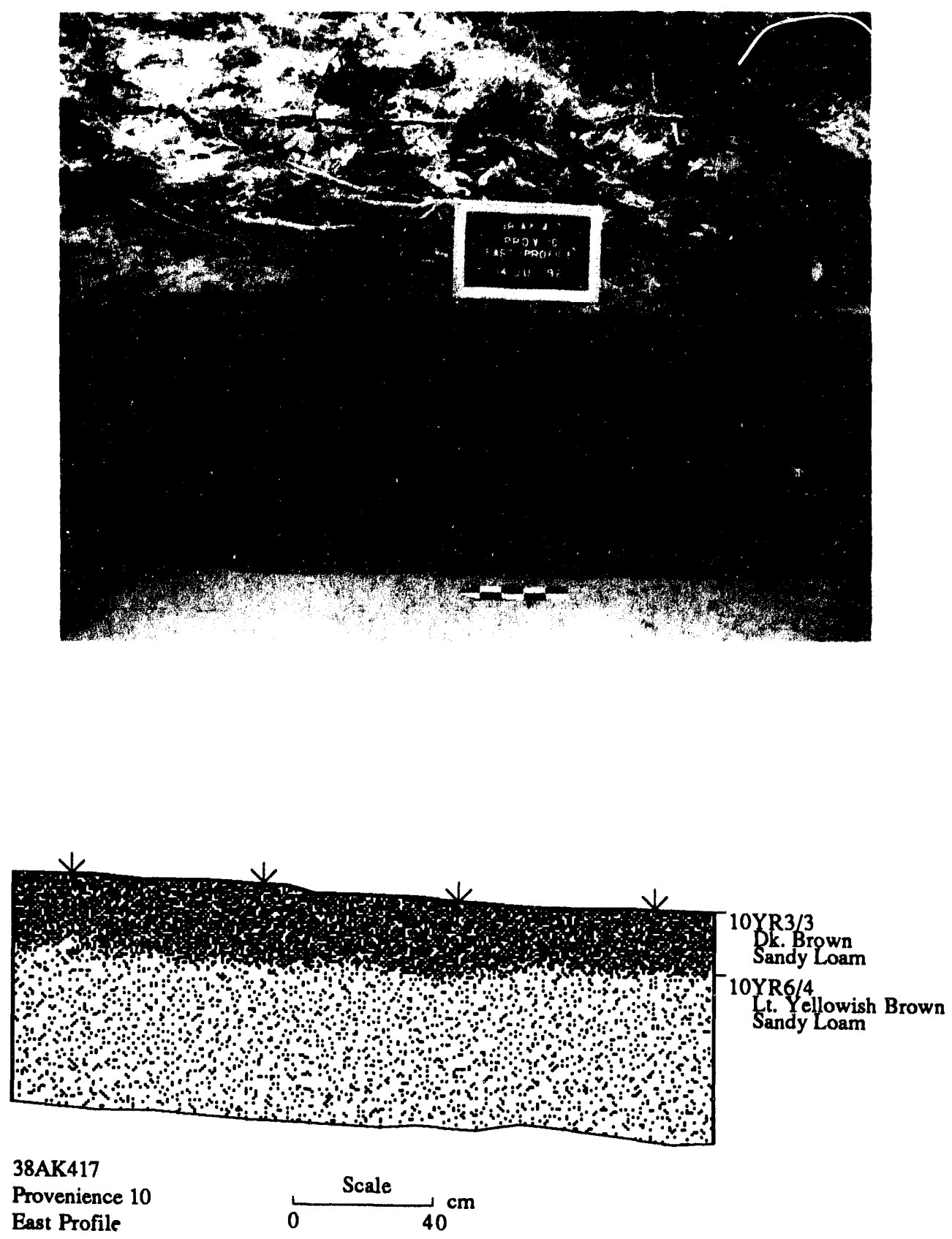

Figure 32. Drawing and photograph of east profile, Provenience 10, 38AK417. 

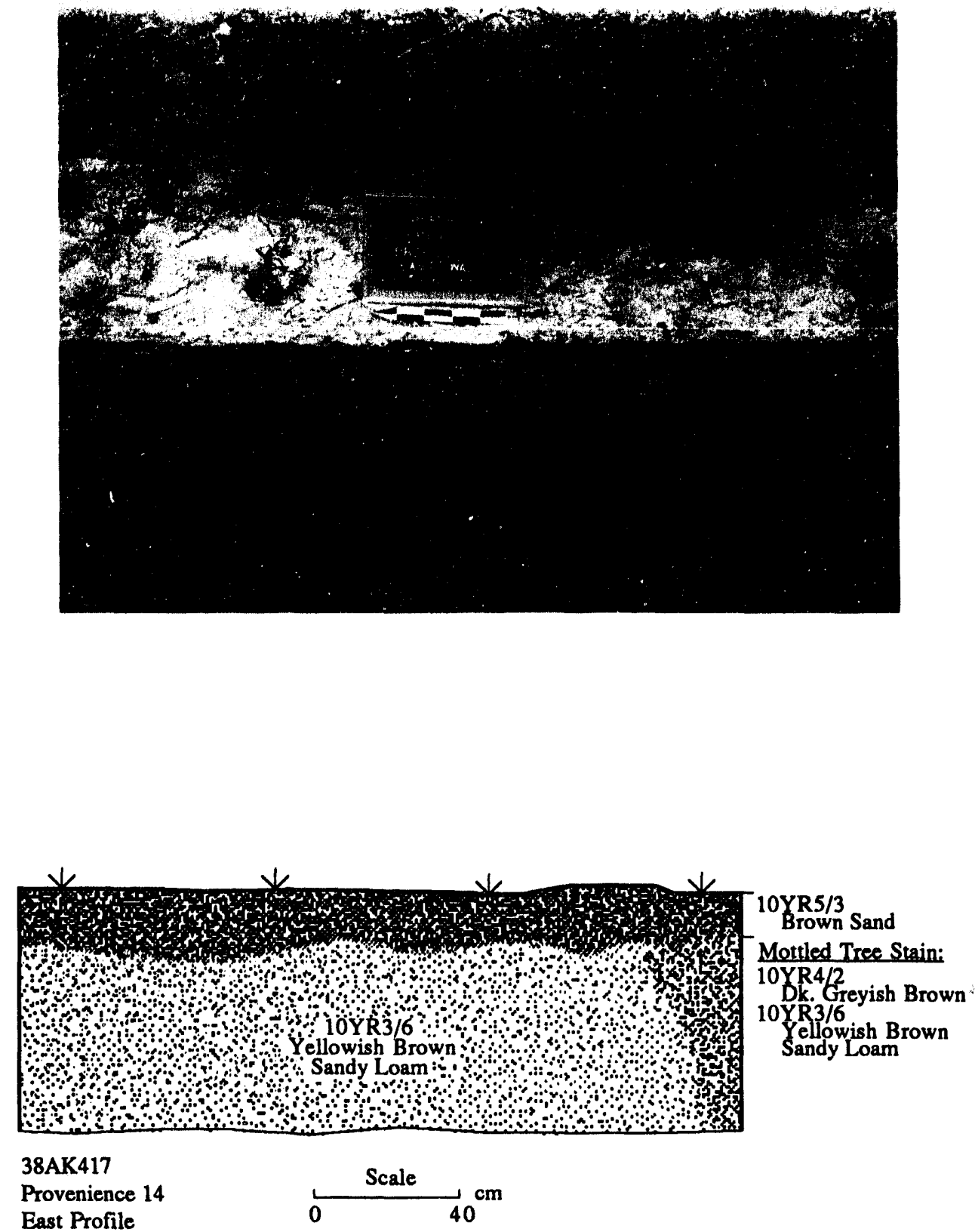

Figure 33. Drawing and photograph of east profile, Provenience 14, 38AK417. 
Table 13. Provenience 10 Artifact Inventory by Level, 38AK417.

\begin{tabular}{lcccccc}
\hline & \multicolumn{2}{c}{$\begin{array}{c}\text { Lithic } \\
\text { Level }\end{array}$} & Ct. & Debitage \\
Wt (8) & Sherds & Ct. & Wt.(g) & TOTAL \\
\hline A & 5 & 4.7 & $2^{\text {a }}$ & & & 7 \\
B & 6 & 1.6 & $1^{b}$ & 1 & 0.2 & 8 \\
C & 3 & 0.6 & & & & 3 \\
D & 3 & 0.6 & & & & 3 \\
B & & & & & & 0 \\
B & & & & & & 0 \\
\hline TOTALS & 17 & 7.5 & 3 & 1 & 0.2 & 21 \\
\hline
\end{tabular}

a one sand-tempered plain and one crumb sherd; ${ }^{b}$ one sand-tempered eroded sherd

Table 14. Provenience 14 Artifact Inventory by Level, 38AK417.

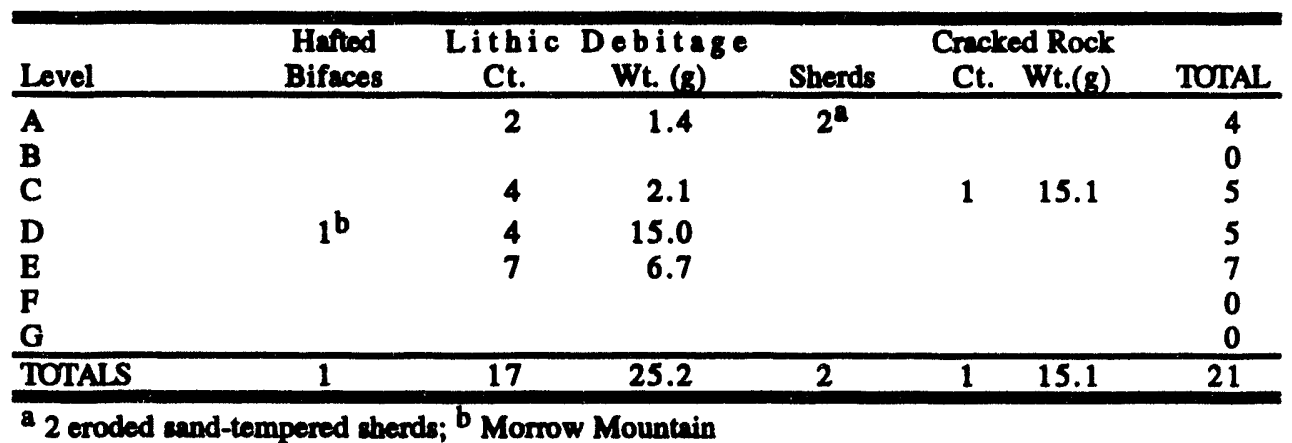

indicative of a Middle Archaic component (Coe 1964; Sassaman et al. 1990: 151-153). Lithic debitage $(\mathrm{N}=17)$ was found in all artifact bearing levels with the highest frequency in the lowest of these levels $(40-50 \mathrm{~cm}$ BS). Level A yielded the only ceramics in the assemblage. These are represented by two eroded sand-tempered plain sherds.

In sum, to investigate the integrity of subsurface deposits, two test units were excavated in separate locations at the site. Provenience 10 was placed in the central portion of the site and Provenience 14 was located along the northeast boundary. Both test units yielded the same quantity of cultural items. Moreover, the recovery frequency $(n=21$ for each test unit) was relatively low when compared to other Aiken Plateau sites (e.g. Sassaman 1989, 1992a) indicating that the overall artifact density at 38AK417 is sparse. In addition to low density, the test unit excavations produced only one diagnostic artifact. The superposition of artifact types suggest that deposits are fairly well stratified. Sandtempered plain sherds, in all likelihood associated with the Middle to Late Woodland components, are contained primarily within the plowzone and a hafted biface, representing a Middle Archaic component, is present at about $40 \mathrm{~cm}$ BS. Although the multiple component subsurface remains at 38AK417 appear intact and fairly well stratified, the research potential is somewhat diminished by the ephemeral nature of these deposits as demonstrated by the test unit excavation results.

Site 38AK417 contains archaeological deposits to a depth of $50 \mathrm{~cm}$ BS dating from the Middle Archaic and Middle to Late Woodland periods. It is apparent from the combined 1984 and 1992-93 artifact assemblages that the Middle Woodland Deptford period habitation is well represented at the site. The presence of cord-marked pottery in the collections suggests a Late Woodland occupation, although the persistence of this pottery type throughout the Middle-Late Woodland and Early Mississippian periods minimizes its reliability as a temporal marker. The small triangular point recovered in 1984, however, 
strongly supports a Late Woodland, and possibly Early Mississippian, habitation and is presumably associated with at least some if not all of the cord-marked ceramics.

\section{$38 A K 419$}

Site 38AK419 was originally discovered during the 1984 Cooling Pond survey of Fourmile Branch (Martin et al. 1985). However, due to its location outside the area of direct impact, a description of the site was not included in the final survey report. The site is located along the northwestern terrace edge of Fourmile Branch (Table 15, Figure 19). At the time of initial survey, the area was planted in mature pines. The soil type is classified as Troup, which consists of well drained sand found on Coastal Plain ridge tops and slide slopes. Topographically, the site is located on a terrace at an elevation of approximately $240 \mathrm{ft}$ above mean sea level and a distance of $600 \mathrm{~m}$ northwest of Fourmile Branch. Site 38AK 419 was characterized as a small ceramic scatter consisting of five Woodland period cord-marked sherds from the same vessel. Two shovel tests were excavated near the sherd cluster on opposite sides of the firebreak to investigate subsurface deposits. No artifacts were recovered in either test and site size was estimated at $5 \times 5 \mathrm{~m}$.

Efforts to relocate 38AK419 during the trunk line survey consisted of subsurface testing and the inspection of exposed ground surface. The area is presently covered in immature planted pines thereby obscuring most surface visibility. Six shovel tests, spaced $30 \mathrm{~m}$ apart, were excavated to detect buried deposits (Figure 28). In addition, the survey team walked two recently plowed firebreaks in the area (continuations of the firebreaks bordering the nearby six-acre tract [Figure 22]). No artifacts were observed on the surface and none were recovered in the shovel tests. In all probability, the site represents nothing more than a one-time event in which a single vessel was dropped and broken while being transported. This type of isolated, fragmented vessel occurrence is not uncommon archaeologically, and is usually referred to as a "pot-bust."

Table 15. Specifications for site 38AK419.

\begin{tabular}{ll}
\hline Cultural Components & Middle-Late Woodland \\
Descriptive Site Type & Cenamic scatter \\
Site Dimensions & $5 \times 5 \mathrm{~m}$ \\
Depth of Cultural Material & Unknown \\
Landform Location & Ridge slope \\
Elevation AMSL & $240 \mathrm{ft}$ \\
Elevation Above Nearest Rank 3 Stream & $60 \mathrm{ft}$ \\
Distance to Water & $500 \mathrm{~m}$ \\
Soil Type & Sand \\
Soil Classification & Troup \\
Soil Description & Well drained \\
Ground Cover & Moderate \\
\hline \hline
\end{tabular}

$38 A K 436$

Site 38AK436 was originally recorded in 1989 during survey for the Telecommunication Center (SR-88 Site Use 89-48-C, SRARP 1989a:3). Situated on a ridge slope at an elevation of $290 \mathrm{ft}$ above mean sea level, this prehistoric site is about 1200 $m$ west of of Tim's Branch, a Rank 3 tributary of Upper Three Runs Creek (Table 16, Figure 19). The forest cover, consisting of a pine plantation, recently had been logged. A 
Table 16. Specifications for site 38AK436.

\begin{tabular}{ll}
\hline Cultural Components & Late Archaic \\
Descriptive Site Type & Isolated Find \\
Site Dimensions & N/A \\
Depth of Cultural Material & Unknown \\
Landform Location & Ridge slope \\
Elevation AMSL & $290 \mathrm{ft}$ \\
Elevation Above Nearest Renk 3 Stresm & $130 \mathrm{ft}$ \\
Distance to Water & $725 \mathrm{~m}$ \\
Soil Type & Loamy sand \\
Soil Classification & Orangeburg \\
Soil Description & Well drained \\
Ground Cover & Lisht \\
\hline
\end{tabular}

walkover survey of the entire clearcut resulted in the recovery of an isolated Late Archaic Savannah River stemmed hafted biface.

In an attempt to relocate 38AK436 during the trunk line survey, ten shovel tests were excavated along a power line right-of-way in the alleged location of the site (Figure 24). All ten tests were negative. Based on these results coupled with the fact that no other cultural debris besides a Savannah River stemmed point was found during the 1989 clearcut survey, 38AK436 is interpreted as a single event activity site where an expended biface was removed from its haft and discarded.

\section{$38 A K 465$}

Site 38AK465 was discovered during intensive survey of the six-acre tract along the northwestern margin of Fourmile Branch (Table 17, Figure 19). The site is characterized as a low density lithic scatter of unknown prehistoric origin. Approximately $10 \times 20 \mathrm{~m}$ in size (Figure 22), 38AK465 is situated on a ridge slope in a transitional vegetation zone consisting of mature slash pine (Pinus elliottii), yellow pine, (Pinus spp.) and bottomland hardwoods. The soil type consists of well drained sand in the Blanton series. The site was located during pedestrian coverage of a recent firebreak where three chert flakes were exposed on the freshly plowed surface. In an attempt to determine site extent and integrity, seven shovel test pits were excavated in a cruciform pattern. This effort resulted in only one positive test, which produced a single chert flake. It seems apparent from this unimpressive assemblage of four flakes, that 38AK465 represents the retouching activity of a transient tool user.

Table 17. Specifications for site 38AK465.

\begin{tabular}{ll}
\hline Cultural Components & Unknown prehistoric \\
Descriptive Site Type & Lithic scatter \\
Site Dimensions & $10 \times 20 \mathrm{~m}$ \\
Depth of Cultural Material & $20 \mathrm{~cm} \mathrm{BS}$ \\
Landform Location & Ridge slope \\
Elevation AMSL & $200 \mathrm{ft}$ \\
Elevation Above Nearest Rank 3 Stream & $30 \mathrm{ft}$ \\
Distance to Water & $300 \mathrm{~m}$ \\
Soil Type & Sand \\
Soil Classification & Blanton \\
Soil Description & Well drained \\
Ground Cover & Moderate \\
\hline
\end{tabular}




\section{CHAPTER 5 \\ CONCLUSIONS}

Archaeological survey for the proposed Wastewater Facility was conducted over a period of 16 days by personnel of the Savannah River Archaeological Research Program. The Wastewater Facility project area consists of a six-acre tract along Fourmile Branch and $29 \mathrm{~km}$ of trunk line corridors. Documentary searches, surface reconnaissance, and the excavation of 159 shovel test pits were employed to discover new sites as well as relocate and delineate the boundaries of existing sites. In addition, three $1 \times 2 \mathrm{~m}$ test units were excavated to sample portions of sites in the areas of direct impact.

One new site and six previously recorded sites were implicated in this project. Intensive survey of the six-acre tract along Fourmile Branch resulted in the discovery of a single new site (38AK465). Survey efforts along the trunk line corridors yielded evidence for only two existing sites (38AK415, 38AK419). Three sites (38AK145, 38AK436, 38AK419) could not be relocated due to the ephemeral nature of their cultural deposits and a fourth (38AK92) was destroyed during past construction activities on the SRS. Therefore, the SRARP recommends that these sites are not eligible for nomination to the National Register of Historic Places (NRHP). The remaining sites, 38AK415, 38AK419, and 38AK465, are evaluated for their research potential in the remaining portion of this chapter. Beginning with a assessment of content, probable site function, and integrity, they are then compared to several other sites along Fourmile Branch that were recently located and tested.

Sites 38AK417 and 38AK465 are situated on the low-lying, northeast terrace landform of Fourmile Branch and 38AK415 is located directly opposite along the bluff margin. Information on site sizes, density and diversity for the three sites are presented in Table 18. A cursory glance at these data show that 38AK415 and 38AK417 stand apart from 38AK465 in measurements of site size as well as artifact density and richness. ${ }^{1}$ These obvious distinctions are most certainly related to differences in site function. Based on diagnostic markers, the major cultural components represented at 38AK415 and 38AK417 date to the Middle to Late Woodland periods. The artifact density value in positive shovel test pits (STPs) at 38AK415 appears to be more than twice the frequency per positive test at 38AK417. This is due to a high artifact recovery from two STPs excavated into a lithic reduction feature. When the flakes from these anomalous tests are omitted from the inventory, the frequency of artifacts per positive test drops to 3.8 indicating equitability in overall density at both sites.

Table 18. Combined Recovery Data from Previous and Recent Survey for Sites Located in the Wastewater Facility Project Area.

\begin{tabular}{llrrrrrrc}
\hline Site & Components & $\begin{array}{c}\text { \# } \\
\text { STPs }\end{array}$ & $\begin{array}{c}\text { \# Pos. } \\
\text { STPs }\end{array}$ & $\begin{array}{c}\text { \% Pos. } \\
\text { STPs }\end{array}$ & $\begin{array}{c}\text { \# Arts.l } \\
\text { Pos. STP }\end{array}$ & $\begin{array}{c}\text { Surface } \\
\text { Arts. }\end{array}$ & $\begin{array}{c}\text { Assemblage } \\
\text { Richness }\end{array}$ & $\begin{array}{c}\text { Site } \\
\text { Size (ha) }\end{array}$ \\
\hline 38AK415 & MWhWW & 54 & 25 & 46.3 & 6.5 & 0 & 5 & 0.75 \\
38AK417 & MA, MW/LW & 78 & 17 & 21.8 & 2.8 & 86 & 4 & 1.20 \\
38AK465 & Unk. prehistoric & 7 & 1 & 14.3 & 1.0 & 3 & 1 & 0.02 \\
\hline
\end{tabular}

*MA=Middle Archaic; EW=Early Woodland; LW=Late Woodland; Unk.=Unknown

\footnotetext{
${ }^{1}$ Artifact richness refers to the number of artifact classes present in an assemblage sample. The classes used in this analysis are very general and include pottery, debitage, hafted bifaces, other bifaces, unifaces, and fire-cracked rock. Sites yielding rich assemblage samples reflect a wide variety of functions, presumably the result of sustained site use by a group of people, minimally a household or two.
} 
Although assemblage density is somewhat low when compared to other sites in the Aiken Plateau, 38AK415 and 38AK417 still have the potential to provide information on upland occupations. Factors contributing to low density are possibly related to site size and level of reoccupation. The extensive scatter of cultural debris at 38AK415 and 38AK417 suggests that the bluff and terrace landforms were repeatedly occupied by small groups. Moreover, the large size of these landforms would not spatially restrict habitation loci. Groups, therefore, probably reoccupied different portions of each landform resulting in extensive and less dense artifact accumulations than would be found on small landforms.

Assemblage richness at 38AK 415 and 38AK417 is comparable, though ceramic and biface variability is greater at the latter site. This may be attributed to more frequent reoccupations at 38AK417, which covers an area almost twice the size of 38AK415. The research potential of 38AK 415 is not compromised by a lack of artifact variability given the presence of a well preserved sub-plowzone lithic feature. This substantial concentration of debitage is probably indicative of a household related activity area that serves as indirect evidence of a nearby structure. Thus, the intensive subsurface testing at 38AK415 and 38AK417 suggests that both sites represent the remains of seasonal, or multiseasonal, upland habitation areas. Large block excavations at these two sites would certainly contribute to our understanding of settlement and site structure during the Middle to Late Woodland periods in the Aiken Plateau. In contrast, 38AK465 is characterized as a small scatter of lithic debris that is attributed to the retouching activity of a transient tool user. As such, 38AK465 does not have the potential to further our knowledge of prehistoric upland site use.

Recently, an extensive survey was conducted along the upper reaches of Fourmile Branch to the north of the Wastewater Facility sites under consideration. The proposed F/H Area Surface Enhancement Project included a 200-acre tract in F-Area and a 280-acre tract in H-Area located along the low-lying terrace margin (Sassaman and Gillam 1993). Of eleven sites located during the survey, only five (38AK146, 38AK535, 38AK539, 38AK541, and 38AK543) were deemed sufficient in content and integrity to yield information regarding upland occupation. As Table 19 shows, the density, diversity and measurements of site size are comparatively similar to 38AK415 and 38AK417. All F/HArea sites have major components dating to the Middle and/or Late Woodland periods; however, unlike the Wastewater Facility sites, evidence for Early Woodland occupations was recovered at three F/H-Area sites. Other components predating the Middle/Late Woodland periods in the two site groups are represented by Middle and Late Archaic artifacts and late prehistoric settlement is represented by a Mississippian component. This information indicates an increased utilization of Fourmile drainage through time beginning as early as the Middle Archaic and culminating during the Middle and Late Woodland

Table 19. Recovery Data for Sites Located in the F/H Tract Project Areas.

\begin{tabular}{llcccccc}
\hline Site & Components* & STPs & $\begin{array}{c}\text { \# Pos. } \\
\text { STPs }\end{array}$ & $\begin{array}{c}\text { \% } \\
\text { STPs }\end{array}$ & $\begin{array}{c}\text { \# Arts } \\
\text { Pos. STP }\end{array}$ & $\begin{array}{c}\text { Assemblage } \\
\text { Richness }\end{array}$ & $\begin{array}{c}\text { Site } \\
\text { Size (ha) }\end{array}$ \\
\hline 38AK146 & EW, MW, LW & 31 & 11 & 35.5 & 2.4 & 6 & 0.95 \\
38AK535 & EW, LW & 26 & 8 & 30.8 & 6.5 & 6 & 0.60 \\
38AK539 & MWLW & 14 & 7 & 50.0 & 7.3 & 3 & 0.24 \\
38AK541 & EW, MW, LW & 32 & 11 & 34.4 & 2.2 & 6 & 0.49 \\
38AK543 & LA, LW, Miss. & 17 & 8 & 47.1 & 4.1 & 6 & 0.15 \\
\hline
\end{tabular}

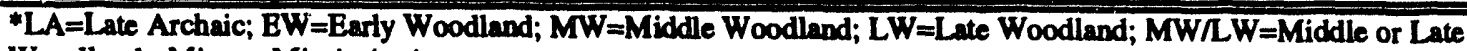
Woodland; Miss.= Mississippian 
periods. Settlement after this time appears to have substantially decreased although small horticultural groups may have occupied sites for only a few years (due to soil nutrient depletion) which would result in low artifact densities that are difficult to detect.

In a broader perspective, comparisons of sites along Fourmile Branch to those of Upper Three Runs reveal differences in size and density. Sassaman and Gillam (1993:68) compiled density data from the F/H-Area and four excavated sites along the bluff margin of Upper Three Runs as shown in Table 20. As they point out, sites in the Fourmile drainage are smaller and less dense than those investigated along Upper Three Runs, with the most obvious difference being site size. Excavation data from the Wastewater Facility sites adheres to this pattem. Interestingly, the largest site investigated along Fourmile Branch (38AK417), although half the size than the smallest site on Upper Three Runs, is represented by the least dense assemblage. This may be attributed to the extensive landform on which 38AK417 is located. With no spatial constraints on subsequent occupations, low artifact density is a possible result. However, this is not the case at most sites along Fourmile where landform and site size are generally small but density is high. Density comparisons between the site groups on Fourmile and Upper Three Runs tend to suggest that the Wastewater Facility and F/H-Area sites were not as intensively occupied through time as Upper Three Runs sites. Other noted differences include the fact that only two sites along Fourmile yielded evidence for components predating the Early Woodland period, while all four of the Upper Three Runs sites contained substantial Late Archaic deposits. Moreover, Early Woodland period components, although present in the $\mathrm{F} / \mathrm{H}$ Area tract, are not as conspicuous as at the Upper Three Runs sites. Only components of

Table 20. Comparisons of Test Unit Artifact Density and Size for Sites along Fourmile Branch and Upper Three Runs Creek.

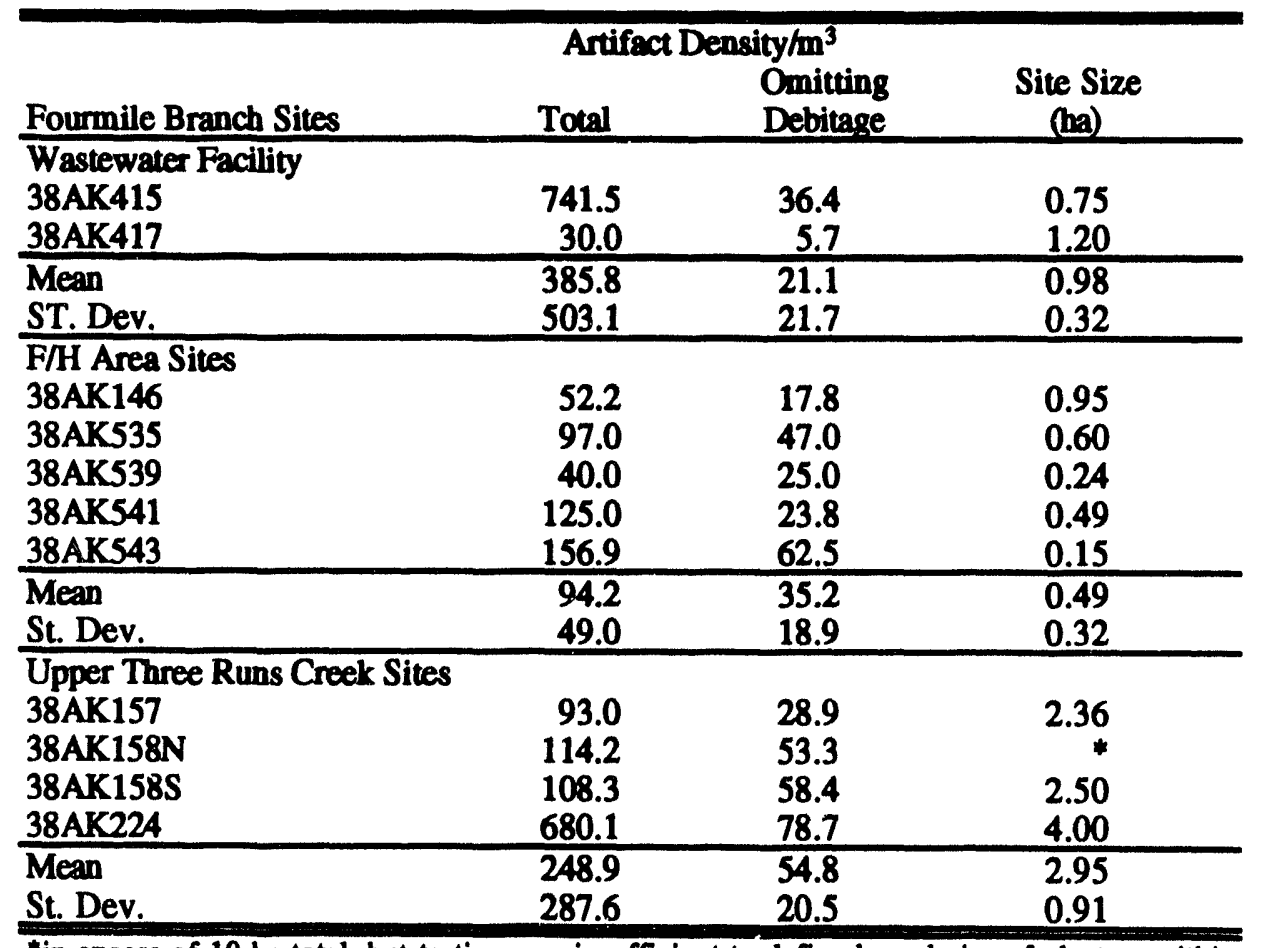

*in excess of 10 ha total, but testing was insufficient to define boundaries of clusters within this area. 
the Middle and Late Woodland periods exhibit equal representation in the two locations. The distinctions in site size, density, and component representation among resources within the two drainages might seem to lessen the research potential of sites along Fourmile. What must be considered however, is that the Wastewater Facility and F/H-Area sites are not simply smaller versions of the Upper Three Runs sites, but rather different resources.

In evaluating the significance of the F/H-Area sites, Sassaman and Gillam (1993) posed three research questions of their data as follows:

(1) Why were sites in the Fourmile Branch drainage not as intensively utilized in the Late Archaic and Early Woodland periods as sites in the Upper Three Runs Creek drainage?

(2) Why were Fourmile Branch sites not intensively utilized until the Middle Woodland period?

(3) Were sites on the low-lying terrace landforms along Fourmile Branch occupied to take advantage of floodplain habitat for farming or other subsistence pursuits?

Given the temporal and locational association of the Wastewater Facility sites to those in the F/H-Area, these questions are also relevant in evaluating the significance of 38AK415, 38AK417, and 38AK465. In seeking answers to the first question, Sassaman and Gillam (1993:69) evoked sociopolitical factors as opposed to ecological explanations for precipitated expansion of upland settlement in the Late Archaic period (see Chapter 2) which precluded intensive use of Fourmile Branch sites. In short, Fourmile Branch sites were too close to the Savannah River to fulfill the needs of group fissioning. Data to test this idea can be obtained from extensive excavations that capture intrasite spatial patterning indicative of household size, interhousehold spacing, local group affiliation, and extralocal relations. Answers to the second question also seemingly hinge on factors that are sociopolitical in nature. Sassaman and Gillam (1993:69-70) explain that the strictures which precluded intensive use of Fourmile Branch sites during the Late Archaic period apparently had dissolved by $2000 \mathrm{BP}$ as marked by the return of intensive riverine occupations in the Savannah River Valley at sites such as Lewis-West (38AK228W), Pie (38BR450), White's Mound, and 38AL2. The intensive use of Fourmile during the Middle Woodland period possibly reflects a retum to a more integrated and institutional group organization than evident during the last few centuries of the Late Archaic when large riverine sites were abandoned. Sites such as those in the Wastewater Facility project area and $\mathrm{F} / \mathrm{H}$-Area Tracts provide an opportunity to systematically investigate this issue. Finally, in addressing the third question, Sassaman and Gillam (1993:70) point out that the sites on the low-lying terrace margin of Upper Three Runs have not been excavated. The data generated from excavation of such sites as 38AK417 and those of the F/H-Area would provide the first opportunity of compare floodplain margin sites with bluff sites. The information from such comparisons might indicate that an increase occurred in the use of floodplain habitat during the Middle and Late Woodland periods that might be related to early horticultural practices.

In sum, two of the sites located during the Wastewater Facility project are characterized by sufficiunt content and integrity to provide information relevant to the sorts of questions outlined above. Although cultural remains at 38AK415 and 38AK417 are, for the most part, neither very dense nor extensive their potential to yield important information is great. Along with the F/H-Area sites, 38AK417 would provide the first opportunity to compare floodplain margin sites with bluff sites along Upper Three Runs. Within the little studied Fourmile Branch drainage, the investigation of $38 \mathrm{AK} 415$ would provide data from 
a bluff margin site hat could be compared to sites situated along the low-lying terrace margins for possible differences in site structure and function.

\section{Recommendations}

Seven archaeological sites were implicated during survey for the proposed Wastewater Facility project (Table 21). Of these, one previously recorded site (38AK92) was severely disturbed from past construction activities and, despite substantial survey efforts, no archaeological evidence was recovered for three other existing sites (38AK145, 38AK 419, 38AK436) due to the ephemeral nature of their cultural deposits. Lacking further evidence for the existence of these four sites, the SRARP maintains that 38AK92, 38AK 145, 38AK 419, and 38AK436 are not eligible for nomination to the National Register of Historic Places and we recommend:

that Savannah River Field Operations Office of the Department of Energy request from the South Carolina State Historic Preservation Office a determination of no effect from construction of the Central Sanitary Wastewater Facility for 38AK92, 38AK145, 38AK419, 38AK436.

Archaeological investigations of the six-acre Wastewater Facility tract resulted in the discovery of one small prehistoric lithic scatter designated 38AK465. This cultural resource does not contain sufficient content, subsurface integrity, or the research potential to add significantly to archaeological knowledge of human occupation in the region. The SRARP therefore maintains that 38AK465 is not eligible for nomination to the National Register of Historic Places and we further recommend:

that Savannah River Field Operations Office of the Department of Energy request from the South Carolina State Historic Preservation Office a determination of no effect from construction of the Central Sanitary Wastewater Facility for 38AK465.

Two existing sites (38AK415 and 38AK417) relocated during survey required further investigation to evaluate their archaeological significance. Both of the sites have sufficient content, subsurface integrity, and the research potential to yield significant data on the prehistoric period occupation of the Aiken Plateau. The SRARP therefore maintains that they are eligible for nomination to the NRHP and we further recommend:

that Savannah River Field Operations Office of the Department of Energy request from the South Carolina State Historic Preservation Office a determination of no effect through mitigation of adverse effects from construction of the Central Sanitary Wastewater Facility for 38AK415 and $38 A K 417$.

Mitigation of adverse effects on sites 38 AK 415 and 38AK417 can be achieved through preservation. Given the limited scale of the adverse effects in the proposed Wastewater Facility trunk line project, preservation of these resources is possible through avoidance. Trunk line construction involves spanning the wetland of Fourmile Branch. Adverse effects to 38AK415 and 38AK417 can be altogether avoided by also spanning both sites during trunk line installation, or if this is undesirable or impossible, by diverting this portion of the trunk line route as to completely avoid the sites. If preservation through avoidance can not be guaranteed, the SRARP will provide a research design for data recovery that will mitigate any adverse effects from land-altering activities of the Wastewater Facility trunk line installation. 
Table 21. Evaluation and Recommendations for Sites in the Wastewater Facility Project Area.

\begin{tabular}{llccl}
\hline Site & Components & $\begin{array}{c}\text { Subeurface } \\
\text { Integrity }\end{array}$ & $\begin{array}{c}\text { NRHP } \\
\text { Eligibility }\end{array}$ & Recommendations \\
\hline 38AK92 & Unknown prehistoric and historic & Poor & No & No further work \\
38AK145 & Possible Archaic & Poor & No & No further work \\
38AK415 & Middle Woodlend & Good & Yes & Preservation \\
38AK417 & Middle Archaic, Middle/Late Woodland & Moderite & Yes & Preservation \\
38AK419 & Midlle/Lat Woodland & Poor & No & No further work \\
38AK436 & Late Archaic & Poor & No & No further work \\
38AK465 & Unknown prehistoric & Poor & No & No further work \\
\hline
\end{tabular}




\section{REFERENCES CITED}

Anderson, David G.

1987 Prehistoric Ceramics from Four Sites Along the Middle Savannah River 38BR259, 38BR495, 38BR527, and 38BR528. In Late Archaic-Late Woodland Adaptive Stability and Change in the Steel Creek Watershed, South Carolina, by M.J. Brooks and G.T. Hanson. Draft report submitted to Savannah River Operations Office, U.S. Department of Energy. Manuscript on file, Savannah River Archaeological Research Program, South Carolina Institute of Archaeology and Anthropology, University of South Carolina.

Aydellott, D. G.

n.d. Soils of the Savannah River Plant, Aiken, South Carolina. United States Forest Service report on file at the Savannah River Forest Station.

Barry, J.M.

1980 Natural Vegetation of South Carolina. University of South Carolina Press, Columbia.

Braley, Chad O.

1992 Cultural Resources Survey of Selected (FY91) Timber Harvesting Areas on Fort Jackson, Richland County, South Carolina. Report submitted to the U.S. Army Corps of Engineers, Savannah District. Prepared jointly by Gulf Engineers and Consultants, Baton Rouge, Louisiana and Southeastern Archaeological Services, Athens, Georgia.

Braley, Chad O., and T. Jeffery Price

1991 Cultural Resources Survey of Selected (FY90) Timber Harvesting Areas, Fort Gordon, Richmond and Columbia Counties, Georgia. Report submitted to the U.S. Army Corps of Engineers, Savannah District and the Di-ision of Forestry and Engineering, Fort Gordon. Prepared jointly by Gulf Engineers and Consultants, Baton Rouge, Louisiana and Southeastern Archaeological Services, Athens, Georgia.

Brooks, Mark J.

1992 Alluvial Contexts of Site Formation in the Coastal Plain of the Savannah and South Edisto River Valleys. Paper presented at conference entitled "Site Formation Processes: Bioturbation and Gravity as a Factor in Sandy Coastal Plain Sites", Coastal Carolina College, Conway, South Carolina.

Brooks, Mark J., and Glen T. Hanson

1987 Late Archaic-Late Woodland Adaptive Stability and Change in the Steel Creek Watershed, South Carolina. Draft report submitted to Savannah River Operations Office, U.S. - epartment of Energy. Manuscript on file, Savannah River Archaeological Research Program, South Carolina Institute of Archaeology and Anthropology, University of South Carolina.

Brooks Mark J., and Kenneth E. Sassaman

1990 Point Bar Geoarchaeology in the Upper Coastal Plain of the Savannah River Valley, South Carolina: A Case Study. In Archaeological Geology of Nor in America, edited by N.P. Lasca and J. Donahue. Geological Society of America, Centennial Special Volume 4. Boulder, Colorado. 
Brooks, Richard David, and David Colin Crass

1991 A Desperate Poor Country: History and Settlement Patterning on the Savannah River Site, Aiken and Barnwell Counties, South Carolina. Savannah River Archaeological Research Papers 12.

Claflin, William, H., Jr.

1931 The Stalling's Island Mound, Columbia County, Georgia. Peabody Museum of American Archaeology and Ethnology Papers 14(1).

Coe, Joffre L.

1964 The Formative Cultures of the Carolina Piedmont. Transactions of the American Philosophical Society 54(5), Philadelphia.

Crass, David C., and Elizabeth Abel

1992 Investigation of Early Historic Settlements on the Savannah River Site. Manuscript on file, Savannah River Archaeological Research Program, South Carolina Institute of Archaeology and Anthropology, University of South Carolina.

Hanson, Glen T., Richard D. Brooks, and John W. White

1981. The Human Occupation Along the Steel Creek Floodplain: Results of an Intensive Archaeological Survey for the L-Area Reactivation Project, Savannah River Plant, Barnwell County, South Carolina. Research Manuscript Series 173, South Carolina Institute of Archaeology and Anthropology, University of South Carolina, Columbia.

Hanson, Glen T., Jr., Rachel Most, and David G. Anderson

1978 The Preliminary Archaeological Inventory of the Savannah River Plant, Aiken and Barnwell Counties, South Carolina. Research Manuscript Series 134, South Carolina Institute of Archaeology and Anthropology, University of South Carolina, Columbia.

King, Adam, and Chad O. Braley

1992 Cultural Resources Survey of Selected (FY92) Timber Harvesting Areas, Fort Gordon, Richmond and McDuffie Counties, Georgia. Report submitted to the U.S. Army Corps of Engineers, Savannah District and the Division of Forestry and Engineering, Fort Gordon. Prepared jointly by Gulf Engineers and Consultants, Baton Rouge, Louisiana and Southeastern Archaeological Services, Athens, Georgia.

Langley, T.M., and W.M. Marter

1973 The Savannah River Plant Site. Report DP-1323. Savannah River Laboratory, Aiken, South Carolina.

Ledbetter, R. Jerald

1991 Archaeological Investigations at Mill Branch Sites 9WR4 and 9WRI1, Warren County, Georgia. Report submitted to J.M. Huber Corporation, Wrens, Georgia. Southeastern Archeologial Services, Athens, Georgia.

Martin, Debra K., Glen T. Hanson, Jr., and Richard D. Brooks

1985 An Intensive Archaeological Survey of Potential Cooling Ponds for Pen Branch and Four Mile Creek, Savannah River Plani, Aiken and Barnwell Counties, South Carolina. Research Manuscript Series 198, South Carolina Institute of Archaeology and Anthropology, University of South Carolina, Columbia. 
Michie, James L.

1990 Bioturbation and Gravity as a Potential Site Formation Process: The Open Area Site, 38GE261, Georgetown County, South Carolina. South Carolina Antiquities Volume 22:27-46.

Rogers, V. A.

1990 Soil Survey of the Savannah River Plant Area, Parts of Aiken, Barnwell and Allendale Counties, South Carolina. United States Department of Agriculture, Soil Conservation Service.

Sassaman, Kenneth E.

1987 Report of Archaeological Investigations at 38AK158 and 38AK159, Aiken County, South Carolina. Report submitted to Savannah River Operations Office, U.S. Department of Energy. Manuscript on file, Savannah River Archaeological Research Program, South Carolina Institute of Archaeology and Anthropology, University of South Carolina.

1989 Prehistoric Settlement in the Aiken Plateau: Summary of Archaeological Investigations at 38AK158 and 38AK159, Aiken County, South Carolina. South Carolina Antiquities 21:31-64.

1991 Long-term Habitation for Small-scale Societies in the Aiken Plateau. Paper presented at the Southeastern Archaeological Conference, Jackson, Mississippi.

1992a Early Woodland Settlement in the Aiken Plateau: Archaeological Investigations at 38AK157, Savannah River Site, Aiken County, South Carolina. Report submitted to the Savannah River Operations Office, United States Department of Energy. Manuscript on file, Savannah River Archaeological Research Program, South Carolina Institute of Archaeology and Anthropology, University of South Carolina.

1992b Colluvial Sites in the Aiken Plateau. Paper presented at conference entitled "Site Formation Processes: Bioturbation and Gravity as a Factor in Sandy Coastal Plain Sites", Coastal Carolina College, Conway, South Carolina.

Sassaman, Kenneth E., and David G. Anderson

1990 Hafted Biface and Ceramic Typology and Chronology on the SRS. In Native American Prehistory and History in the Middle Savannah River Valley: Synthesis of Archaeological Investigations on the Savannah River Site, Aiken and Barnwell Counties, South Carolina, by K.E. Sassaman, M.J. Brooks, G.T. Hanson, and D.G. Anderson. Savannah River Archaeological Research Papers 1.

Sassaman, Kenneth E., and Mark J. Brooks

1990 Cultural Quarries: Strategies for Scavenging and Recycling Lithic Refuse. Paper presented at the Southeastern Archaeological Conference, Mobile.

Sassaman, Kenneth E., and J. Christopher Gillam

1993 Intensive Archaeological Survey of the F/H Surface Enhancement Project Area, Savannah River Site, Aiken and Barnwell Counties, South Carolina. Technical Report Series Number 18. Savannah River Archaeological Research Program, South Carolina Institute of Archaeology and Anthropology, University of South Carolina. 
Sassaman, Kenneth E., D. Keith Stephenson, and William Green

1992 Intensive Archaeological Survey of the Proposed Site R Sanitary Landfill, Savannah River Site, Aiken and Barnwell Counties, South Carolina. Technical Report Series Number 16. Savannah River Archaeological Research Program, South Carolina Institute of Archaeology and Anthropology, University of South Carolina.

Sassaman, Kenneth E., Mark J. Brooks, Glen T. Hanson, and David G. Anderson

1990 Native American Prehistory and History in the Middle Savannah River Valley:

Synthesis of Archaeological Investigations on the Savannah River Site, Aiken and Barnwell Counties, South Carolina. Savannah River Archaeological Research Papers 1.

Savannah River Archaeological Research Program (SRARP)

1989a Archaeological Resource Management Plan of the Savannah River Archaeological Research Program. Report submitted to the Savannah River Operations Office, United States Department of Energy. Manuscript on file, Savannah River Archaeological Research Program, South Carolina Institute of Archaeology and Anthropology, University of South Carolina.

1989b Fiscal Years 1988-1989 Annual Report on the Savannah River Archaeological Research Program. Report submitted to the Savannah River Operations Office, United States Department of Energy. Manuscript on file, Savannah River Archaeological Research Program, South Carolina Institute of Archaeology and Anthropology, University of South Carolina.

1990 Annual Review of Cultural Resource Investigations by the Savannah River Archaeological Research Program. Report submitted to the Savannah River Operations Office, United States Departinent of Energy. Manuscript on file, Savannah River Archaeological Research Program, South Carolina Institute of Archaeology and Anthropology, University of South Carolina.

1992 Annual Review of Cultural Resource Investigations by the Savannah River Archaeological Research Program. Report submitted to the Savannah River Operations Office, United States Department of Energy. Manuscript on file, Savannah River Archaeological Research Program, South Carolina Institute of Archaeology and Anthropology, University of South Carolina.

Shelford, Victor E.

1963 The Ecology of North America. University of Illinois Press, Chicago.

Stevenson, Ann E.

1982 Geomorphic History of a Portion of the Savannah River Floodplain, Barnwell County, South Carolina. Unpublished MA Thesis, Department of Geology, University of South Carolina, Columbia.

United States Atomic Energy Commission Aerial Photographs

1951 Savannah River aerial photographs 1951. U.S. Department of Energy, Savannah River Operations Office, Aiken, SC. 
Whipple, Stephen A.

1978 Report for 1978 on the Research Project: A Gradient Analysis of Bottomland and Swamp Forest of the Savannah River Plant, South Carolina. Report by the Department of Botany, Louisiana State University on file at the Savannah River Ecology Laboratory, University of Georgia.

Whipple, Stephen A., Lynn H. Wellman, and Bill J. Good

1981 A Classification of Hardwood and Swamp Forests of the Savannah River Plant, South Carolina. Savannah River Plant National Environmental Research Park Program, Report SR-NERP-6. 

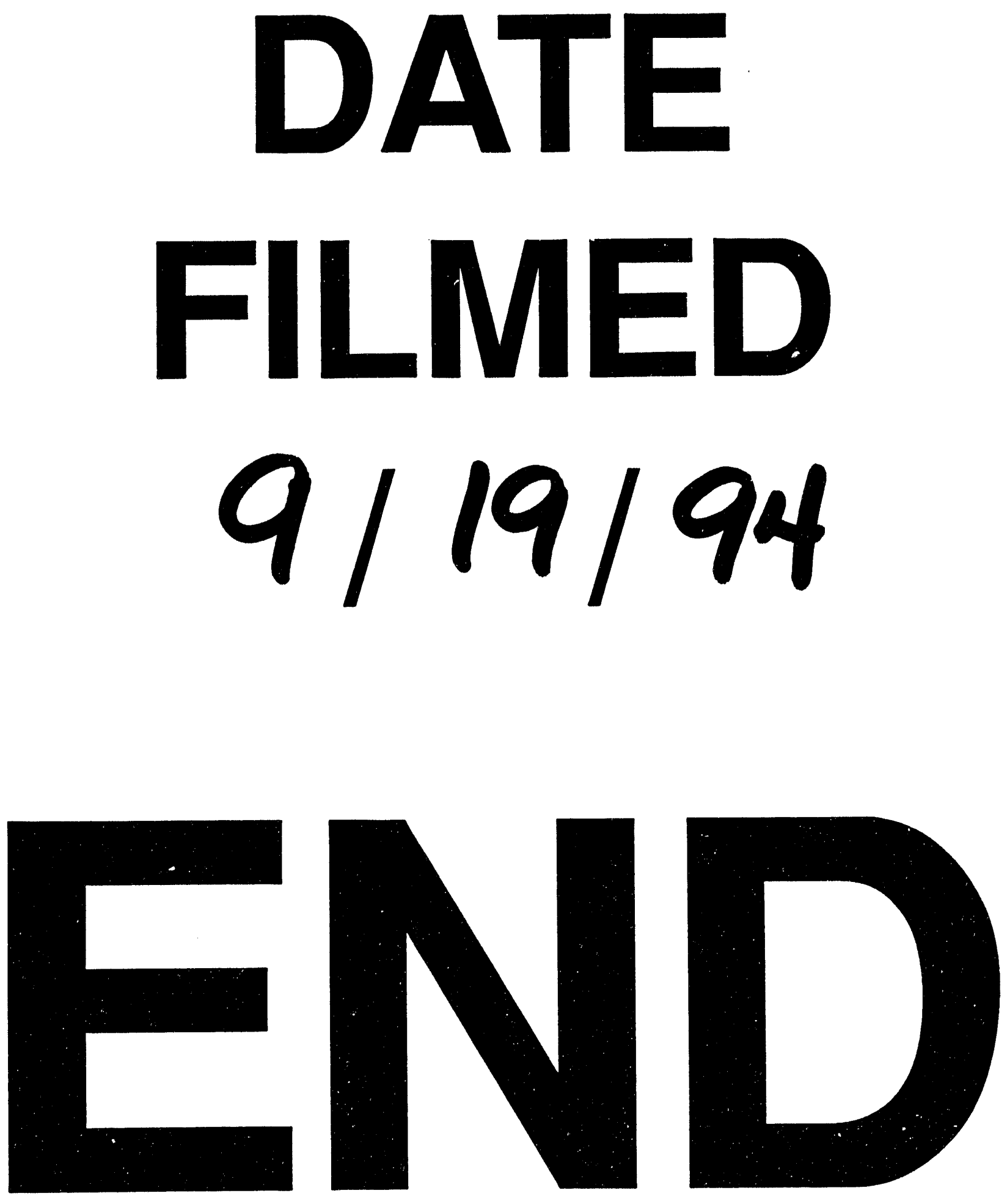
